\title{
WestVirginiaUniversity
}

THE RESEARCH REPOSITORY @ WVU

Graduate Theses, Dissertations, and Problem Reports

2011

\section{Mechano-enzymatic pretreatment of lignocellulosic biomass}

\author{
Bibu Philip George \\ West Virginia University
}

Follow this and additional works at: https://researchrepository.wvu.edu/etd

\section{Recommended Citation}

George, Bibu Philip, "Mechano-enzymatic pretreatment of lignocellulosic biomass" (2011). Graduate Theses, Dissertations, and Problem Reports. 4718.

https://researchrepository.wvu.edu/etd/4718

This Dissertation is protected by copyright and/or related rights. It has been brought to you by the The Research Repository @ WVU with permission from the rights-holder(s). You are free to use this Dissertation in any way that is permitted by the copyright and related rights legislation that applies to your use. For other uses you must obtain permission from the rights-holder(s) directly, unless additional rights are indicated by a Creative Commons license in the record and/ or on the work itself. This Dissertation has been accepted for inclusion in WVU Graduate Theses, Dissertations, and Problem Reports collection by an authorized administrator of The Research Repository @ WVU.

For more information, please contact researchrepository@mail.wvu.edu. 
Bibu Philip George

\author{
Dissertation submitted to the \\ Davis College of Agriculture, Natural Resources \& Design \\ at West Virginia University \\ in partial fulfillment of the requirements \\ for the degree of
}

Doctor of Philosophy

In

Forest Resources Science

Benjamin Dawson-Andoh, Ph. D., Chair

James Armstrong, Ph. D.

John Renton, Ph. D.

Eugene Felton, Ph. D.

Ben Spong, Ph. D.

Division of Forestry and Natural Resources

Department of Wood Science and Technology

Morgantown, West Virginia

2011

Keywords: Pre-treatment, Enzyme hydrolysis, Wet attrition, Electron Beams

Copyright 2011 Bibu Philip George 


\section{ABSTRACT \\ MECHANO-ENZYMATIC PRETREATMENT OF LIGNOCELLULOSIC BIOMASS \\ Bibu Philip George}

Recalcitrance of lignocellulosic cell wall is a major hurdle that needs to be disrupted for biochemical refinery to be successful. Pretreatment of lignocellulosic materials play a key role for the conversion of lignocellulosic feed stocks to fermentable sugars. At present, various pretreatment technologies mainly achieved by empirical methods are available for the production of sugars from lignocellulosic polysaccharides. These methods depend largely upon the "demolition" of the cell wall by strong chemicals or using high energy input. As a result, these processes release "smaller compounds" as by-products or end products which inhibits downstream fermentation of monomeric sugars.

This project is a preliminary study to understand the combined effect of mechanical action and enzyme hydrolysis on the yield of sugars from two lignocellulosic biomass viz, hard maple (Acer saccharum Marsh.) and corn stover (Zea mays L.). The mechanical treatment involves wet attrition milling and the application electron beams. The enzyme treatments are done by using six cell wall depolymerizing enzymes. The amounts of total sugars release after each treatment are measured by Dinitrosalicylic acid (DNS) assay and types of sugars release were determined by High Performance Liquid Chromatography (HPLC) analysis. Particle size were measured by Microtract particle size analyzer and also by image analysis. Treatments that required minimum number of enzymes to produce significantly higher amount of sugars were selected for the 
studying the effect of increased enzyme concentration on the amount of sugars released. Further, the residues from enzyme hydrolysis are analyzed by ATR-FTIR and NMR to understand the degree of depolymerization of cell wall biopolymers. Depolymerizing properties of electron beams on corn stover particulates were also studied. The effects of irradiation on these specimens were evaluated by estimating the amount of total sugars released after the treatment with Accellerase ${ }^{\circledR} 1000$.

This study has shown that the enzymatic digestibility of a pretreated hard maple and corn stover are enhanced by reducing the particle size. A significant increase in the yield of sugars were also observed in the treatments that were pretreated with CDTA (1,2-Cyclohexylenedi nitrilotetraacetic Acid) and BSA (Bovine Serum Albumin). Presence of glucose and xylose were confirmed by HPLC (High Performance Liquid Chromatography) analysis. Lower sugar yields were measured after the treatment corn stover with electron beams. Future studies are required to understand the effect of the sequence of the enzymes for a higher sugar yield and also to combine other pretreatment methods with electron beams for a better deconstruction of lignocellulosic cell wall. 


\section{DEDICATION}

To George Philip and Marykutty George, my parents for their endless love, encouragement, support and personal sacrifices

To Merina George, my wife, for her understanding and encouragement. I could not have completed this effort without her support, patience, and enthusiasm

To Jenika Mary George, my daughter adding happiness into our life in spite her father was not available, than should have been in the last few months of my studies.

Dr. Joseph P. Varhees, former Head of the Department of Botany, CMS College, Kottayam for his encouragement and support

All friends, family members and teachers for my achievements from my elementary education to this award of Doctoral Degree. 


\section{ACKNOWLEDGEMENTS}

I would like to express my sincere gratitude to my advisor Dr. Benjamin Dawson-Andoh for instilling in me the qualities of being a good scientist and rendering me all the guidance required for the successful completion of this work. I sincerely appreciate all my committee members; Dr. Jim Armstrong, Dr. John Renton, Dr. Eugene Felton and Dr. Ben Spong for their time, valuable suggestions and effort during the course of undertaking this research and writing this dissertation.

I am grateful to Mr. Chuck Major for the help with wet attrition. Thanks go to Mr. Liviu Magean for providing us Scanning Electron Microscopy results. Thanks to Electron Beams, MA for the help with irradiation studies. I would like to thank Dr. David Murray, NIOSH, Morgantown, WV and Mr. Adam Brant for the help for NMR studies. I thank Dr. Qingzheng Cheng Biofuels for providing facilities for ATR-FTIR analysis.

I am very grateful to all my colleagues; Dr. Oluwatosine Adedipe, Dr. Paul Filson, Kofi Nkansah, Clay Medley, Charile Collins and Gideon Lawer-Yolar for their help and support, advise and friendship made my doctoral studies enjoyable for me. I will remain indebted to all the faculty and staff of Division of Forestry and Natural Recourses, West Virginia University for providing friendly and pleasant working environment.

Above all, I give God the glory for His kindness and divine blessings throughout my life. 


\section{TABLE OF CONTENTS}

List of Tables $\quad x$

List of Figures $\quad$ xii

Chapter 1. Structure of Thesis, Introduction and Objectives 1

1.1 Structure of thesis 1

1.2 Introduction 2

1.2.1 Lignocellulosic biomass as a potential biorefinery feedstock 2

1.2.2 Recalcitrance of lignocellulosic biomass 3

1.2.3 Supramolecular structure of lignocellulosic biomass 6

1.2.4 Action of selected physical, chemical and cell wall depolymerization enzymes 8

1.2.4.1 Physical treatment of lignocellulosic biomass 9

1.2.4.2 Effect of chelation of calcium from pectin network by CDTA 9

1.2.4.3 Effect of bovine serum albumin (BSA) on enzyme activity 10

1.2.4.4 Effect of alkali on lignocellulosic biomass $\quad 10$

1.2.4.5 Depolymerizing effect of enzymes on lignocellulosic biomass $\quad 10$

$\begin{array}{ll}\text { 1.2.4.5.1 Pectinase } & 11\end{array}$

1.2.4.5.2 Proteinase 12

1.2.4.5.3 Ferulic Acid Esterase 12

$\begin{array}{ll}\text { 1.2.4.5.4 Polygalacturonase } & 12\end{array}$

1.2.4.5.5 Xylanase 13

$\begin{array}{ll}\text { 1.2.4.5.6 Endoglucanase } & 13\end{array}$

$\begin{array}{ll}1.3 \text { Approach to study } & 13\end{array}$

$\begin{array}{ll}1.4 \text { Objectives of the study } & 15\end{array}$

$\begin{array}{ll}\text { References } & 16\end{array}$

Chapter 2. Mechano-Enzymatic Pretreatment of Hard Maple (Acer Saccharum

$\begin{array}{ll}\text { Marsh.) } & 22\end{array}$

$\begin{array}{ll}\text { Abstract } & 22\end{array}$

2.1 Introduction 23

2.2 Experimental Design 25

2.3.0. Materials and methods 26 
2.3.1 Materials 26

2.3.1.1. Lignocellulose biomass 26

2.3.1.2. Lignocellulose cell wall deconstruction enzymes 26

2.3.1.3. Chelators and other materials 27

2.3.2. Methods 27

2.3.2.1. Wet Attrition milling of hard maple 27

2.3.2.2. Chemical analysis of untreated and pretreated hard maple $\quad 27$ wood

2.3.2.3. Analysis of particles by Light Scattering Particle Size Analysis, Cold Field Emission Gun Scanning Electron Microscopy (FCEGSEM) and Image Analysis.

2.3.2.4. Sequential enzymatic depolymerization of wood cell wall to remove recalcitrance

2.3.2.5. Analysis of sugars by Dinitrosalyclic acid assay and High Performance Liquid Chromatography 31

2.4. Results and discussion $\quad 32$

2.5. Conclusion $\quad 37$

References 46

Chapter 3. Mechano-Enzymatic Pretreatment of Corn Stover (Zea Mays L.). 49 Abstract 49

$\begin{array}{ll}3.1 \text { Introduction } & 50\end{array}$

3.2 Experimental Design $\quad 52$

3.3.0. Materials and methods $\quad 53$

3.3.1 Materials $\quad 53$

3.3.1.1. Lignocellulose biomass 53

3.3.1.2. Lignocellulose cell wall deconstruction enzymes 53

3.3.1.3. Chelators and other materials 53

3.3.2. Methods 54

3.3.2.1. Wet Attrition milling of corn stover 54

3.3.2.2. Chemical analysis of untreated and pretreated corn-stover 54

3.3.2.3. Analysis of particles by Light Scattering Particle Size Analysis, $\quad 55$ 
Cold Field Emission Gun Scanning Electron Microscopy (FCEGSEM) and Image Analysis.

3.3.2.4. Sequential enzymatic depolymerization of wood cell wall to remove recalcitrance

3.3.2.5. Analysis of sugars by Dinitrosalyclic acid assay and High Performance Liquid Chromatography

3.4. Results and discussion

3.5. Conclusion

References NMR Studies.

Abstract

4.1. Introduction

4.2. Experimental design

4.3.0. Materials and methods

4.3.1. Materials

4.3.1.1. Lignocellulose biomass $\quad 80$

4.3.1.2. Lignocellulose cell wall deconstruction enzymes 80

4.3.1.3. Chelators and other materials $\quad 81$

4.3.2. Methods

4.3.2.1. Wet Attrition milling of lignocellulosic materials.

4.3.2.2. Sequential enzymatic depolymerization of lignocellulosic cell wall to remove recalcitrance

4.3.2.3. Analysis of sugars by 1,3 Dinitrosalyclic acid assay and High Performance Liquid Chromatography

4.3.2.4 Attenuated Total Reflectance (ATR) analysis of corn stover and hard maple wood

4.3.2.5 NMR Spectroscopy of corn stover and hard maple 
References

Chapter 5. Effect of Electron Beam Iiradiation on Mechano-Enzymatic Pretreatment 105 of Lignocellulosic Biomass: ATR-FTIR and Solid-State ${ }^{13} \mathrm{C}$ NMR Studies.

$\begin{array}{ll}\text { Abstract } & 105\end{array}$

5.1. Introduction 106

5.2. Experimental design 107

5.3.0. Materials and methods 108

$\begin{array}{ll}\text { 5.3.1. Materials } & 108\end{array}$

$\begin{array}{ll}\text { 5.3.1.1. Lignocellulose biomass } & 108\end{array}$

5.3.1.2. Evaluation of Lignocellulose cell wall depolymerization. 108

$\begin{array}{ll}\text { 5.3.1.3. Chelators and other materials } & 108\end{array}$

$\begin{array}{ll}\text { 5.3.2. Methods } & 109\end{array}$

5.3.2.1. Wet-Attrition milling of corn stover 109

5.3.2.2. Depolymerization of lignocellulosic cell wall to remove recalcitrance using electron beams. 110

5.3.2.3. Analysis of sugars by 1,3 Dinitrosalyclic acid assay and High Performance Liquid Chromatography 111

5.3.2.4 Attenuated Total Reflectance (ATR) analysis of corn stover and hard maple wood $\quad 111$

5.3.2.5 NMR Spectroscopy of Lignocellulosic biomass 112

5.4. Results and discussion 113

$\begin{array}{ll}\text { 5.5. Conclusion } & 117\end{array}$

$\begin{array}{ll}\text { References } & 124\end{array}$

$\begin{array}{ll}\text { Chapter 6. Conclusion and Recommendation } & 127\end{array}$

6.1 Conclusion 127

6.2 Future Recommendations 129 


\section{LIST OF TABLES}

\section{Chapter 2. Mechano-Enzymatic Pretreatment of Hard Maple (Acer Saccharum}

Marsh.)

Table 2.1. Details of sequential enzymatic treatment of the biomass using seven cell wall depolymerizing enzymes

Table 2.2. Showing details of the amount of sugars produced after each enzymatic treatment without BSA and CDTA in the reaction mixture.

Table 2.3. Showing details of the amount of sugars produced after each enzymatic treatment with BSA and CDTA in the reaction mixture.

Chapter 3. Mechano-Enzymatic Pretreatment of Corn Stover (Zea Mays L.).

Table 3.1. Details of serial enzymatic treatment of the biomass using seven cell wall depolymerizing enzymes.

Table 3.2. Showing details of the amount of sugars produced after each enzymatic treatment without BSA and CDTA in the reaction mixture.

Table 3.3. Showing details of the amount of sugars produced after each enzymatic treatment with BSA and CDTA in the reaction mixture.

Chapter 4. Effect of Cell Wall Depolymerizing Enzyme Concentration on MechanoEnzymatic Pretreatment of Lignocellulosic Biomass: ATR-FTIR and Solid-State ${ }^{13} \mathrm{C}$ NMR Studies.

Table 4.1. Details of serial enzymatic treatment of the biomass using cell wall depolymerizing enzymes for corn stover

Table 4.2. Showing details of the amount of sugars produced after each enzymatic treatment in Corn Stover. 
Table 4.3. Showing details of the amount of sugars produced after each enzymatic treatment in Hard Maple.

Table 4.4. ATR-FTIR band assignments of polysaccharides and sugars

Chapter 5. Effect of Electron Beam Iiradiation on Mechano-Enzymatic Pretreatment of Lignocellulosic Biomass: ATR-FTIR and Solid-State ${ }^{13}$ C NMR Studies.

Table 5.1.Design of experiments.

Table 5.2. Details of the yield of sugars after pretreatment using DNS assay method 


\section{LIST OF FIGURES}

\section{Chapter 1. Structure of Thesis, Introduction and Objectives}

Figure 1.1. Attrition milling forces

\section{Chapter 2. Mechano-Enzymatic Pretreatment of Hard Maple (Acer Saccharum}

Marsh.)

Figure 2.1. A schematic showing details of the experimental protocol used in the present study

Figure 2.2. Showing details of the amount of sugars produced after each enzymatic treatment without BSA and CDTA in the reaction mixture

Figure 2.3. Showing details of the amount of sugars produced after each enzymatic treatment without BSA and CDTA in the reaction mixture

Figure 2.4. HPLC analysis for the presence of sugars after enzymatic treatment -

a. Glucose standard, b. Xylose standard, c. Sample from experiment 13 with BSA \&CDTA

Figure 2.5. Particle size analysis after wet milling (a), after enzymatic treatment (b) and SEM of the particles after enzyme hydrolysis (c).

\section{Chapter 3. Mechano-Enzymatic Pretreatment of Corn Stover (Zea Mays L.).}

Figure 3.1. A schematic showing details of the experimental protocol used in the present study

Figure 3.2.Showing details of the amount of sugars produced after each enzymatic treatment without BSA and CDTA in the reaction mixture 
Figure 3.3. Showing details of the amount of sugars produced after each enzymatic treatment without BSA and CDTA in the reaction mixture

Figure 2.4. HPLC analysis for the presence of sugars after enzymatic treatment -

a. Glucose standard, b. Xylose standard, c. Sample from experiment 13 with BSA \&CDTA

Figure 3.5. (a) Particle size analysis after wet milling, (b), Particle size analysis after enzymatic treatment, (c) SEM of corn stover particles.

\section{Chapter 4. Effect of Cell Wall Depolymerizing Enzyme Concentration on Mechano- Enzymatic Pretreatment of Lignocellulosic Biomass: ATR-FTIR and Solid-State ${ }^{13} \mathrm{C}$ NMR Studies.}

Figure 4.1. A schematic showing details of the experimental protocol used in the present study

Figure 4.2. Showing details of the amount of sugars produced after each enzymatic treatment in Hard Maple.

Figure 4.3 Showing details of the amount of sugars produced after each enzymatic treatment in Corn stover.

Figure 4.4 (a) Corn Stover (b) Hard Maple (c) Glucose standard (d) Xylose Standard

Figure 4.5. ATR-FTIR spectra of pretreated corn stover residue (a) and hard maple residue (b) between 4000 and $500 \mathrm{~cm}^{-1}$

Figure 4.6. ${ }^{13} \mathrm{C}$ NMR spectra of hard maples. (a) Hard maple control, 16k scans; (b) processed hard maple, 32k scans. Spectra were obtained using ${ }^{1} \mathrm{H}^{-}{ }^{13} \mathrm{C}$ cross polarization with $1 \mathrm{~ms}$ contact times and a 2.5 second recycle delays. "Magic angle" spin speed was $5200 \pm 10 \mathrm{~Hz}$. 


\section{Chapter 5. Effect of Electron Beam Iiradiation on Mechano-Enzymatic Pretreatment of Lignocellulosic Biomass: ATR-FTIR and Solid-State ${ }^{13} \mathrm{C}$ NMR Studies.}

Figure 5.1. A schematic showing details of the experimental protocol used in the present study

Figure 5.2. ${ }^{13} \mathrm{C}$ NMR spectra of cornstalk material obtained by ${ }^{1} \mathrm{H}^{-13} \mathrm{C}$ cross polarization.

(a) Control, (b) Willey milled samples. (c) and (d) Attrition milled samples. Spectra are obtained by signal averaging 320000-64000 scans using a 4 ms contact time and a 2.5 second recycle delay.

Figure 5.3. ${ }^{13} \mathrm{C}$ NMR spectra of cornstalk material obtained by ${ }^{1} \mathrm{H}-{ }^{13} \mathrm{C}$ cross polarization.

(a) Corn control; (b) Attrition milled sample; Spectra are obtained by signal averaging about $32 \mathrm{k}$ scans using a 4 ms contact time and a 2.5 second recycle delay.

Figure 5.4. ATR-FTIR spectra of pretreated corn stover residue between 4000 and $500 \mathrm{~cm}^{-1}$ 


\section{CHAPTER 1. STRUCTURE OF THESIS, INTRODUCTION AND OBJECTIVES}

\subsection{Structure of thesis}

This thesis contains six chapters. Chapter one is a general introduction to the study and also contains the objectives of this work.

Chapter's two to six contains which contain four unpublished papers reports of the results of thesis work. Chapters two and three respectively contain papers I and II. These two papers examined the effect of the combined action of mechanical and enzymatic pretreatment of hard maple and corn stover on the yield of total sugars after hydrolysis by the commercial cellulase enzyme, Accelerase ${ }^{\circledR}$ 1000. The amount of total sugars produced was compared with the theoretical yield. The effects of the calcium chelant, 1,2-Cyclohexylenedi nitrilo-tetraacetic Acid (CDTA) and Bovine Serum Albumin (BSA), an enzyme stabilizer, on the activity of depolymerizing enzymes were also determined.

Chapter four of this thesis which contains paper III examined the effect of enzyme concentration on the total turnover of monomeric sugars. It also characterized the chemistry of pretreated wood using Attenuated Total Reflectance-Fourier Transform Infrared spectroscopy (ATR-FTIR) and carbon 13 Nuclear magnetic Resonance Spectroscopy $\left({ }^{13} \mathrm{C}\right.$ NMR analysis $)$.

Paper IV, the final paper of this study is presented in chapter five of this thesis. This paper reports the results of a study which evaluated Electron Beam as pretreatment for corn stover. Additionally, the study also examined the effect of particle size of corn stover on Electron Beam 
as pretreatment for corn stover. The chemistry of Electron Beam pretreated corn stover was studied using ATR-FTIR and ${ }^{13} \mathrm{C}$ NMR.

The overall conclusion and recommendations for future studies are presented in chapter six.

\subsection{Introduction}

\subsubsection{Lignocellulosic biomass as potential biorefinery feedstock}

Lignocellulosic biomass encompassing agricultural (corn stover, bagasse, cereal stalks, etc.) and forest (logging, sawmill, etc.) residues, wood are relatively cheap, abundantly available secondgeneration feed stock for the production of biofuels, biochemical and bioproducts via. the emerging biofinery industry. Using various processes coupled with different technologies, a biorefinery converts biomass to biofuels, power, products and chemicals (Himmel and Picattaggio, 2008). A recent study of the availability of biomass in the US, the Billion-ton study, confirmed that this country has enough land resources (both agricultural and forestry) to produce 3.3 billion tons of dry biomass feed stock per year. This amount of feed stock can displace $30 \%$ of the petroleum needs of this country by 2030 .

There are two biorefinery platforms: thermochemical conversion and biochemical conversion. This study focuses on biochemical conversion. The objective in biochemical conversion process is to convert (saccharify) cellulose and other carbohydrates to D-glucose and monosaccharides. Two major saccharification pathways are recognized: (1) acid hydrolysis using concentrated or multi-stage dilute acid, and (2) "pretreatment" followed by enzymatic hydrolysis. Department of 
Energy evaluation in 1980 suggested that the pretreatment combined with enzymatic hydrolysis in the long term was cheaper for the production of ethanol (Sheehan, and Riley. 2001).

Commercialization of biochemical biorefinery using lignocellulosic biomass feed stock is hampered by a number of factors, notably converting the biomass into an intermediate product that is easy to convert (saccharify) to monosaccharides via cellulose depolymerizing enzymes, cellulases. This process difficulty is called "recalcitrance" and is caused by the physical and chemical structure of the lignocelluosic biomass cell wall at both meso- and micro length scales. In nature, these attributes of plants protect them from invasion by plant pathogens. Commercialization of biochemical biorefineries awaits the development of economic and environmental compatible breakthrough technologies, pretreatments that can remove recalcitrance of biomass.

\subsection{Recalcitrance of lignocellulosic biomass.}

Lignocellulosic biomass cell wall is major repository of monosaccharides such as D-glucose in the form of their macromolecules - cellulose and hemicellulose. It thus represents a viable alternate non-food competitor second generation feedstock for biorefineries. To be economically competitive with current primary biorefinery primary feedstock, corn, a key priority is to increase the yield of the monosaccharide, D-glucose, without the production of chemicals that inhibit downstream processes such as fermentation (Himmel and Picataggio, 2008). This is possible if access by depolymerizing enzymes to cellulose in the lignocelluloses cell wall complex can be enhanced. However, the biomass cell wall which is a nanocomposite of cellulose, enmeshed in a matrix of other macromolecules, lignin, hemicellulose, pectin and 
proteins. Other extraneous micromolecules, called extraneous compounds or extractives and ash, are also present. All these molecules in the cell wall form a complex that poses resistance to access and deconstruction of member biopolymers by biocatalysts - enzymes. For trees and plants in general, this complex acts as physico-chemical barrier to attack by microbial pathogens. This phenomenon is called "recalcitrance". The degree of lignification of plant cell walls (Cosgrove, 2005), the heterogeneity and complexity of cell-wall constituents (Iiyama et al., 1994), inhibitors generated during the conversion processes (Wyman et al., 2005) also benefit recalcitrance of plant cell walls. To use lignocellulosic biomass as a source of D-glucose and other monosaccharides, this barrier needs to be removed or compromised to permit access to the carbohydrate macromolecules by depolymerizing enzymes. To accomplish this, many methods called pretreatment have been developed empirically. They include biological, physical and chemical protocols. Many of the current pretreatment methods are not cost or energy effective and produce chemicals that inhibit downstream processes such as fermentation.

Pretreatment of lignocelluloses is intended to disorganize the crystalline structure of macro- and microfibrils, in order to release the polymer chains of cellulose and hemicellulose, and/or modify the pores of the material to allow enzymes to penetrate into the fibers to render them amenable to enzymatic hydrolysis (Galbe \& Zacchi, 2002). Pretreatment methods are well investigated by many researchers in the past (Carvalheiro et al., 2008, Chandra et al., 2007, Hendriks and Zeeman, 2009, Kumar and Wyman, 2009, Kumar et al., 2009, Taherzadeh and Karimi, 2008, Yang and Wyman, 2008). They report that when dilute acids are used at elevated temperatures, hydrolysis of hemicelluloses with minimum modification of lignin occurs. The use of sulfur dioxide produces lower hydrolysis of hemicelluloses. Phosphoric acid in organic solvents has been used to de-crystalize and solubilize cellulose with promising results (Zhang et al, 2007). 
Alkalis notably ammonia has been employed in different formats: (i) treatment with anhydrous ammonia followed by rapid release (AFEX process, Dale and Moreira, 1982), (ii) ammonia recycle percolation (ARP) - application of aqueous ammonia at elevated temperatures, and soaking in aqueous ammonia (SAA). Although the specific effects of ammonia in the three treatments differ, overall they enhance subsequent hydrolysis to produce higher yields of glucose from cellulose. Pretreatments with alkalis remove lignin and acetyl groups of hemicelluloses. Physical treatments include ball milling (Fan et al, 1980,Inoue et al., 2008), hammer milling (Iñiguez-Covarrubias et al., 2001; Mani et al., 2004), grind milling (Mtui and Nakamura, 2005);roll milling (Qi et al., 2005), vibratory milling (Guerra et al., 2006) and ultrasonification (Imai et al., 2004) high energy radiation and steam explosion (Estaghlalian, et al. 1997). In steam-explosion, lignocellulosic biomass is subjected to high-pressure steam in a retort attended by sudden compression. Lignin is thermoplastic and under this condition, it softens and allows the fibers to be separated. Milling of wood reduces size of wood and increases its surface area to volume ratio.

Many studies shows combinations of physical and chemical methods give better sugar yield than the individual pretreatment techniques. Methods like ARP (90\%), AFEX (93\%) acid hydrolysis (91\%), Steam explosion (90\%), Liquid hot water treatment (85\%) and wet oxidation (74\%) have excellent substrate conversion rates (Dale \& Moreira, 1982, Wyman et al., 2005, Kalman et al., 2002, Lloyd et al., 2005, and Öhgrenet al., 2005). But all these techniques were developed "empirically"; may inhibit downstream processes and negatively impact the environment.

Many of these empirically derived pretreatments produces inhibitors of downstream processes; operate at severe temperature and pressures; consume a lot of energy. In nature, lignocellulosic biomass can be partially or total hydrolyzed by a mixture of enzymes. This is approach is 
increasingly being considered by many research groups as viable pretreatment method. From a practical point of view, the challenge for this approach is the selection of enzymes to participate in this process and their mode of application. The approach adopted in this study is to use the current understanding of the supramolecular structure of the biomass cell wall and the nature of reported linkages between the macromolecules in the cell wall in the coice of depolymerizing enzymes. Although the supramolecular structure of the cell wall is not completely elucidated, our knowledge has improved considerably in the past decade. This approach represents the overall objective of this study.

\subsubsection{Supramolecular structure of lignocellulosic biomass}

The primary macromolecules of lignocellulosic biomass are: cellulose, hemicellulose, lignin, pectin, and proteins. Cellulose is a homopolymer consisting of linear chains of $(1 \rightarrow 4)$ - $\beta$-linkedD-glucose monomers. The repeating unit is cellobiose. The glucan molecules are held together by hydrogen bonding to form microfibrils (diameters: 4-10 nanometers) (Evert, 2007). Presence of water in microfibtrils significantly affects its diameter. Like threads in a rope, microfibrils aggregate to form macrofibrils ( 0.5 micron $X$ 4-7 micron). In the microfibrils, some of the cellulose are orderly organized - crystalline (micelles), whilst in other regions their arrangement is disorderly - amorphous.

Cellulose microfibrils are enmeshed in a polysaccharide matrix of hemicellulose, pectins and structural proteins (glycoproteins). Hemicelluose is a group of heterogenous non-linear $(1 \rightarrow 4)-\beta$ linked-D-amorphous polysaccharides. In the primary cell wall, the major hemicellulose is

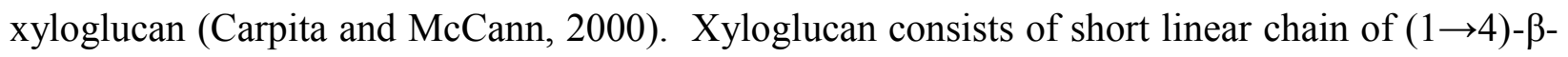


linked-glucan with short-side chains of xylose, galactose and fucose. Xyloglucan controls cell wall enlargement by tethering cellulose microfibrils through hydrogen-bonding to its surface. Two types of primary cell walls are recognized: Type I and Type II. In type I, the dominant hemicellulose is xyloglucan. Other hemicelluloses include glucuronoarabinoxylans. In the secondary cell wall, angiosperms principally contain xylans whilst glucomannans are found in gymnosperms.

Pectins are of two types, polygalacturonic acid and rhamnogalacturonan and form a gel-like network structure with cellulose. They are found primarily in the primary cell wall (30-50\% by dry weight in dicotyledons and 2-3\% in monocots). They are usually absent in the secondary cell wall and are cross-linked by calcium ions and boron.

Structural proteins which constitute about $10 \%$ by dry weight of the primary cell wall are of three types: hydroxyl-rich proline rich proteins (HRGPs), proline-rich proteins (PRPs) and glycine-rich proteins (GRPs). HRGPs occur primarily in phloem, cambium, sclerenchyma; PRPs and GRPs in xylem. Another class of protein, expansin, has been reported to induce loosening of cell wall. Many enzymes such as cellulases, phosphatases, peroxidases, pectinases, etc are found in the cell wall.

Lignins are phenyl-propane-based polymer consisting of primary three basic units: p-coumaryl, coniferyl, and sinapyl alcohols. Lignin displaces water in the cell wall and imparts hydrophobicity. It acts also as a binding agent and contributes to the compressive and bending strength of the cell wall. Lignin limits lateral diffusion of water in xylem and enhances its longitudinal transport. Lignin also inhibits microbiodeterioration and this way contributes to the "recalcitrance" of the biomass cell wall. 
Two models of primary cell wall have been proposed. Generally, the primary cell wall consists of a network of cellulose mirofibrils-hemicelluose enmeshed in a gel of pectin. In one model, cellulose microfibrils are tethered by surface coating of hemicelluloses (xyloglucan). Some covalent bonding also occurs. This cellulose-hemicellulose network is largely (70\% approximately) responsible for the total strength of the primary wall.

Therefore, this network can be partially broken down by hydrolysis of the hemicelluloses. In the second model, cellulose microfibrils are bound by hemicellulose which is embedded in pectin. The space between cellulose microfibrils are filled by pectin.

Secondary cell wall contribute significantly to the strength properties of the xylem. Secondary cell usually lacks pectin and structural proteins but has higher cellulose content than the primary cell wall. It consists of three layers: S1, S2, and S3. Whilst cellulose microfibrils are randomly arranged in the primary wall, in the secondary, they are helically arranged.

Various covalent and physical bonds link all these macromolecules in the biomass cell wall notably with cellulose. Thus access to cellulose in the cell wall can be increased by breaking the chemical and physical linkages between cellulose and the macromolecules in the matrix. This process can be described as "deconstruction" of the cell wall.

\subsubsection{Action of selected physical, chemical and cell wall depolymerization enzymes}

Plant cell wall is an interwoven matric of biopolymers. Combining physical and chemical pretreatments increases the accessibility of cell wall depolymerizing enzymes to its substrates. Attrition milling of lignocellulosic biomass increases the surface to volume ratio for providing 
more access for the enzyme hydrolysis. Alkaline conditions remove ester-linked side chains such as acetyl and feruloyl side groups cell wall macromolecules and solubilizes hemicellulose. CDTA removes calcium from pectin macromolecular structures and compromises the pectin structure. BSA binds to the lignin and hence decreases the inhibitory effects of lignin during the enzymatic depolymerization of cell wall bioploymers.

\subsubsection{Physical treatment of lignocellulosic biomass}

Decreasing the surface area to volume ratio increases access of enzymes to the macromolecules in the biomass cell wall. This can be accomplished by many physical processes such as hammermilling, ball milling and attrition milling to name a few. Attrition milling will be used in this study. It combines impact and shearing forces to reduce the size of a particle. It is appropriate for mid-size particles $(3-10 \mathrm{~mm})$ and can reduce their sizes to 1-10 microns. In this process, the material is placed in a grinding media within a stationary tank. A rotating shaft then agitates the material and media to reduce the size of particle (Figure 1).

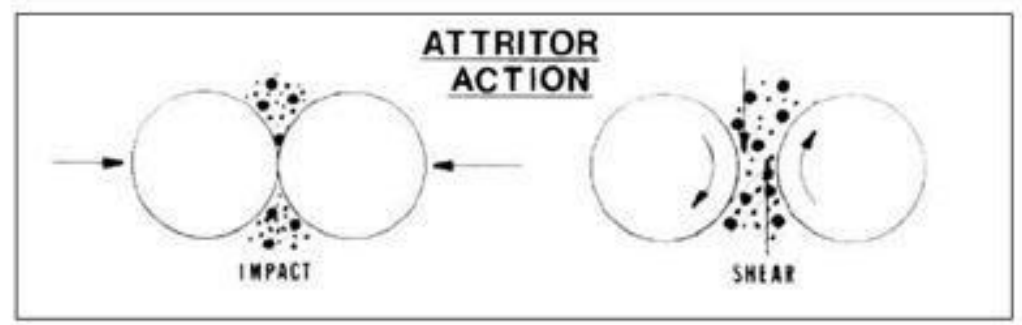

Figure 1.1. Attrition milling forces 
Source: Choose the right grinding mill. Consider the feed material's nature and milling objective. Robert E. Schilling, Union Process Inc.

http://www.chemicalprocessing.com/articles/2010/172.html

\subsubsection{Effect of chelation of calcium from pectin network by CDTA}

The pectin macropolymer in the biomass cell wall is reinforced by calcium ions. Subsequently, sequestration of calcium ions from the pectin-cellulose-lignin network will compromise the this network and probably increase the pore structure of the cell wall leading to enhanced penetration by depolymerzing enzymes. Removal of $\mathrm{Ca}^{++}$ions is critical for the hydrolysis of pectic acid.

\subsubsection{Effect of bovine serum albumin (BSA) on enzyme activity}

Lignin is hydrophobic and may inactivate enzymes through physical bonding. Yang \& Wyman (2006) reported that the addition of BSA before the addition of cell wall depolymerizing enzymes causes lignin to bind to BSA. Subsequent addition of cellulase enzymes is therefore not inhibited.

\subsubsection{Effect of alkali on lignocellulosic biomass}

Sodium hydroxide pretreatment can increase the removal of lignin from the lignocellulosic biomass. This would enhance the accessibility for the cell wall hydrolyzing enzymes to the polysaccharides by decreasing the amount of inhibitory compounds present in the reaction 
mixture. Alkali pretreatment causes swelling of cellulosic fibers and thus increases the internal surface area (Sun and Cheng, 2002). It also decreases the crystalinity of cellulose molecules, and also creates disruption of structural linkages between the cell wall biopolymers (Mosier et al, 2005).

\subsubsection{Depolymerizing effect of enzymes on lignocellulosic biomass}

Degradation of the plant cell wall polymers will require he synergistic action of several hydrolytic enzymes such as hemicellulases, xylanases, pectinases and esterases (Beg et al, 2001). Following enzymes are used for the current study for depolymerizing the cell wall biopolymers by their combined and substrate specific action.

\subsection{Pectinase}

Addition of pectinase can increase the digestion of non-cellulosic saccharides and can increase the cellulose hydrolysis (Zhang, 2009). CDTA sequesters $\mathrm{Ca}^{2+}$ from pectin in the cell wall, by opening up the junction zones between pectin molecules which are held by $\mathrm{Ca}^{2+}$ (Wehr et al., 2004). This would increase the accessibility of pectinase enzymes to pectin present in the cell wall. Pectinase removes methoxyl groups from pectin substances. It also splits the glycosidic linkages by $\beta$-elimination of hydrogen from the C- 4 and C- 5 position (Green et al., 1996, Lima et al., 2002). 


\subsection{Proteinase}

Plant cell walls contain structural proteins called as extensins that form intermolecular crosslinks with lignin and cellulose molecules. This would decrease the accessibility of depolymeriszing enzymes to other cell wall bio-polymers as well as polysaccharides resulting in lower yield of monomeric sugars (Fry, 1986). It is critical to use protein digesting enzymes to break lignin cellulose cross-links, thereby, opening up the cell wall polysaccharides to cellulases.

\subsection{Ferulic Acid Esterase.}

Ferulic acid is cross-linked to arabinoxylans through diferulate esters and to lignin to form the ferulate-polysaccharide-lignin complex. The linkage to polysaccharides occurs via ester bond between carboxylic acid group of ferulic acid and the primary alcohol of the arabinose side chain of arabinoxylans. The linkage to lignin occurs through ether bonds. Feruloyl acid esterases act synergistically with xylanases, cellulases and pectinases to breakdown complex plant cell wall carbohydrates (Saha, 2003, Sorensen et al, 2003, Buanafina, 2009).

\subsection{Polygalacturonase}

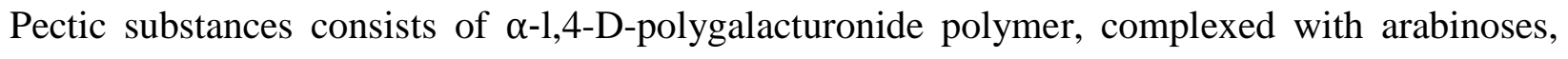
galactans and rhamnogalacturonases. Side chains of pectic polymers consists of galactose, arabinose, rhamnose, xylose and glucose (Pilnik and Voragen, 1991; Redgwell et al, 1992). Polygalacturonase hydrolyses polygalacturonic acid chains of pectin to sugars. This property of this polygalacturonase can be synergistically utilized along with pectinase and CDTA to increase the total sugar yield. 


\subsection{Xylanase}

Xylans are found in all plant cell walls and are built upon a poly-B-(1 $\rightarrow 4)$-xylopyranose backbone. Xylans are categorized according to their substituents of their side chains (Decker et al, 2008). Most of the xylanses can hydrolyse multiple xylans and regardless exo or endo-xylan they act on the end of the chain yielding monomeric xylose. Since xylose is a constituent of lignocellulosic feedstocks it is important to use xylanses for a successful depolymerization of cellwall.

\subsection{Endoglucanase}

Endoglucanases have a high affinity to cellulose and synergistically reacts with other depolymerizing enzymes cleaving $B-(1 \rightarrow 4)$ or $B-(1 \rightarrow 3)$ linkages interior of the glucose chains (Decker et al, 2008, Himmel et al, 1997). Thomas et al (1995) reported that even adding small quantities of endoglucanases results in drastic increases in monomer yields due to synergistic interaction between endoglucanases and other depolymerizing/hydrolyzing enzymes. Therefore it is necessary to use endoglucanases with other enzymes to increase the sugar yield.

\subsection{Approach to study}

A complete degradation of the biomass cell wall can be accomplished by use of cell wall depolymerizing enzymes that act synergistically to breakdown crucial chemical bonds amongst the matrix macromolecules and cellulose. These enzymes can be employed as a cocktail or 
sequentially. Sequential application of cell wall depolymerizing enzymes in this approach enables the synergistic effect of individual enzymes on the deconstruction of the lignocellulosic biomass cell wall to be studied. This is the approach adopted in this study. The lignocellulosic biomass cell wall depolymerizing enzymes and other agents such as chelating and enzymes stabilizers selected is based upon their reported ability in the literature to break the chemical bonds linking the matrix macromolecules to the structural cellulosic macromolecule or their contribution to this process. The order in which these cell wall depolymerizing enzymes are employed may be important but this was not evaluated in this study. One order of sequential application of cell wall depolymerizing enzymes was selected and maintained throughout the study. The depolymerizing enzymes selected are: pectinase, proteinase, FAE, polygalacturonase, xylanase and endoglucanase. The associated agents are milling, sodium hydroxide, CDTA and Bovine Serum Albumin (BSA). 


\subsection{Objectives of the study}

The study comprised of two parts. The first part evaluated the effect of pretreatment of biomass by of combination of physical (mechanical) and sequential treatment with commercially available cell wall depolymerizing enzymes on the yield of total sugars, - mechano-enzymatic pretreatment. All pretreated biomass is treated with the commercial cellulase enzyme complex, to convert the "free" cellulose to conversion of carbohydrates in biomass to sugars. The second part of the study determined the effect of electron beam treatment on the yield of total sugars from biomass treated with the commercial cellulase enzyme complex, Accelerase ${ }^{\circledR}$ (GeneCor Inc.). Physical/mechanical treatment of biomass is effected by attrition milling.

Specific objectives include:

1 To determine the effect of wet attrition milling to reduce particle size and increase surface area of biomass.

2 To determine the effect of sequential treatment of wet-attritor milled wood with cell wall depolymerizing enzymes total sugar yield

3 To investigate the effect of concentration of cell wall depolymerizing enzymes on total sugar yield.

4 To investigate the effect of electron beam treatment on total sugar yield. 


\section{References}

Beg, Q.P, Kapoor, M., Mahajan, L., Hoondal, G.S., 2001. Microbial xylanases and their industrial applications: a review. Appl. Microbiol. Biotechnol. 56: 326-338.

Buanafina, M. M. de O, 2009. Feruloylation in Grasses: Current and future perspectives. Mol. Plant, 2 (5): 861-872

Carpita, N.C. and McCann, M.C. (2000) The cell wall. In: Biochemistry and Molecular Biology of Plants (Eds. B.B. Buchanan, W. Gruissem, R. Jones), American Society Plant Physiologists, Rockville, MD, pp 52-109.

Carvalheiro, F., Duarte, C., and Gírio, F. M., 2008. Hemicellulose biorefineries: a review on biomass pretreatments, J. Sci. Ind. Res., 67 , pp. 849-864

Chandra, R.P., Bura, R., Mabee, W.E., Berlin, A., Pan X., and Saddler, J.N., 2007. Substrate pretreatment: the key to effective enzymatic hydrolysis of lignocellulosics?, Adv. Biochem. Eng. Biotechnol., 108, pp. 67-93

Cosgrove, D. J., 2005. Growth of the plant cell wall, Nature Reviews Molecular Cell Biology, 6, pp. $850-861$.

Dale, B. E., Moreira, M. J. 1982. Freeze-explosion technique for increasing cellulose hydrolysis.Biotechnol.Bioeng. Symp.12, 31-43.

Decker, S. R., Sika-aho, M. and Viikari, L. 2008. Enzymatic depolymerization of plant cell wall hemicelluloses, in: Himmel, M. E (Eds.), Biomass Recalcitrance: Deconstructing the Plant Cell Wall for Bioenergy, Blackwell Publishing Ltd, Oxford, UK pp. 1- 6. 
Esteghlalian, A. Hashimoto, A.G., Fenske, J.J. and Penner, M.H., 1997. Modeling and optimization of the dilute-sulfuric acid pretreatment of corn stover, poplar and switchgrass. Bioresource Technol. 59, 129-136

Evert, R. F., (2007) Easu's Plant Anatomy Meristems, Cells and Tissues of the Plant Body Their Structure, Function and Development., Wiley Interscience.

Fan, L.T., Lee, Y. and Beardmore, D.H.,1980. Mechanism of the enzymatic hydrolysis of cellulose: Effects of major structural features of cellulose on enzymatic hydrolysis. Biotechnol.Bioeng., 22, 177-199

Fry, S.C., 1986. Cross-linking of matrix polymers in the growing cell walls of angiosperms, Ann. Rev. Plant Physiol., 37: 165-186.

Galbe, M. and Zacchi, G., 2002. A review of the production of ethanol from softwood. Appl. Microbiol. Biotechnol. 59, 618-628.

Green, F., Kuster, T. A. and Highley, T. L., (1996). Pectin Degradation during Colonization of Wood by Brow-rot Fungi. Rescent Res. Devel. In Plant Pathology, 1, 83-93.

Guerra, A,, Filpponen, I., Lucia, L. A., Saquing, C., Baumberger, S.,Argyropoulos, D.S., 2006. Toward a better understanding of the ligninisolation process from wood, J. Agric. Food Chem., 54 (16), pp.5939-5947.

Hendriks, A.T.W.M. and Zeeman, G., 2009.Pretreatments to enhance the digestibility of lignocellulosic biomass, Bioresour. Technol., 100, pp. 10-18.

Himmel, M. E., Adney, W. S., Baker, J. O., Elander, R., McMillan, J. D., Nieves, R. A., Sheehan, J. J., Thomas, S. R., Vinzant, T. B. and Zhang, M. 1997. Advanced Bioethanol 
Production Technologies: A Perspective. in: Saha, B. C., Woodward, J., (Eds.), Fuels and Chemicals from Biomass. ACS Symposium Series 666. Washington, DC: American Chemical Society, 1, pp. 2-45.

Himmel, M. E., and Picataggio, S. K., 2008.Deeper Understanding of Biomass Recalcitrance, in: Himmel, M. E (Eds.), Biomass Recalcitrance: Deconstructing the Plant Cell Wall for Bioenergy, Blackwell Publishing Ltd, Oxford, UK pp. 1- 6.

Iiyama, K., Lam, T. B. T., Stone, B. A., 1994. Covalent Cross-Links in the Cell Wall, Plant Physiol. 104, pp. 315.

Imai, M., Ikari, K. and Suzuki, I., 2004. High-performance hydrolysis of cellulose using mixed cellulase species and ultrasonication pretreatment. Biochem.Engg.J., 17(2). pp. 79-83.

Iñiguez-Covarrubias, G., Lange, S. E. and Rowell, R. M., 2001. Utilization ofbyproducts from the tequila industry: part 1: Agave bagasse as a rawmaterial for animal feeding and fiberboard production, Bioresour.Technol., 77(1). pp. 25-32.

Inoue, H., Yano, S., Endo, T., Sakaki, T. and Sawayama, S, 2008. Combining hot-compressed water and ball milling pretreatments to improve the efficiency of the enzymatic hydrolysis of eucalyptus. Biotechnol Biofuels., 1 (1):2.

Kalman G., Varga E., and Reczey K., 2002.Diluted sulphuric acid pretreatment of corn stover at long residence times. Chem. Biochem. Eng. 16(4), 151-157.

Kumar, P., Barrett, D.M., Delwiche M.J. and Stroeve, P., 2009. Methods for pretreatment of lignocellulosic biomass for efficient hydrolysis and biofuel production, Ind. Eng. Chem. Res., 48, pp. 3713-3729. 
Kumar, R and Wyman, C.E., 2009. Effects of cellulase and xylanase enzymes on the deconstruction of solids from pretreatment of poplar by leading technologies, Biotechnol.Prog.,25, pp. 302-314.

Lima, A., Alegre, R. and Meirelles, A., 2002. Partitioning of pectinolytic enzymes in polyethylene glycol/potassium phosphate aqueous two-phase systems. Carbohydr Polym 50:6368.

Lloyd T. A., Wyman C. E., 2005. Combined sugar yields for dilute sulfuric acid pretreatment of corn stover followed by enzymatic hydrolysis of the remaining solids. Bioresour. Technol. 96, 1967-1977.

Mani, S., Tabil, L. G. and Sokhansanj, S., 2004. Grinding performance andphysical properties of wheat and barley straws, corn stover andswitchgrass.Biomass Bioenergy, 27(4).pp.339-352.

Mosier, N., Wyman, C., Dale, B., Elander, R., Lee, Y. Y., Holtzapple, M. and Ladisch, M., 2005. Features of promising technologies for pretreatment of lignocellulosic biomass. Bioresour. Technol., 96, 673-686.

Mtui, G., and Nakamura, Y. 2005. Bioconversion of lignocellulosic waste fromselected dumping sites in Dar es Salaam, Tanzania Biodegradation, 16(6). pp. 493-499.

Öhgren, K., Galbe, M., Zacchi, G., 2005.Optimization of Steam Pretreatment of SO2Impreganted Corn Stover for Fuel Ethanol Production. Appl. Biochem. and Biotech. 121, 10551068. 
Pilnik, W. and A.G.J. Voragen, 1991. The Significance of Endogenous and Exogenous Pectic Enzyme in Fruit and Vegetable Processing. In: Food Enzymology, Fox, P.F. (Ed.). Elsevier Science Publishers, Amsterdam, pp: 303-336.

Qi, B., C., Aldrich, C., Lorenzen, L. and Wolfaardt, G.W. 2005. Acidogenicfermentation of lignocellulosic substrate with activated sludge, Chem.Eng. Communications, 192(9). pp. 12211242.

Redgwell, R.J., Melton, L.D. and Brasch, D.J., 1992. Cell wall dissolution in ripening kiwifruit (Actinidia deliciosa): solubilisation of the pectic polymers. Plant Physiol., 98: 71-81.

Saha, B.C. 2003. Hemicellulose conversion. J. Ind. Microbiol. Biotechnol. 30: 279-291

Sheehan, J. and Riley, C. 2001. Annual Bioethanol outlook: FY 2001. Internal NREL-DOE report. National Renewable Energy Laboratory, Golden, Co.

Sorensen, H. R, Meyer, A. S. and Pedersen, S. 2003. Enzymatic hydrolysis of waters soluble wheat arabonoxylan. I. Synergy between $\alpha$-L-arabinofuranosidases, endo-1,4- $\beta$-xylanases, and $\beta$ xylosidase activities. Biotechnol. Bioeng. 81: 726-731

Sun, Y. and Cheng, J., 2002. Hydrolysis of lignocellulosic materials for ethanol production: a review. Bioresour. Technol., 83, 1-11.

Taherzadeh, M.J. and Karimi, K., 2008.Pretreatment of lignocellulosic wastes to improve ethanol and biogas production: a review, Int. J. Mol. Sci., 9, pp. 1621-1651.

Thomas, S.R., Laymon, R.A., Chou, Y-C., Tucker, M.P., Vinzant, T.B., Adney, W.S., Baker, J.O., Nieves, R.A., Mielenz, J.R. \& Himmel, M.E. 1995. Initial approaches to artificial cellulase systems for conversion of biomass to ethanol, in: Saddler, J.N. and Penner, M.H. (Eds.), 
Enzymatic Degradation of Insoluble Carbohydrates, ACS Symposium Series 618, Washington, DC, 208-236

Wehr, J. B., Menzies, N. L. and Blamey, F.P.C., 2004. Inhibition of cell wall autolysis and pectin degradation by cations. Plant Physiol. Biochem., 42: 485-492.

Wyman.,C. E., Dale, B. E., Elander, R. T., Holtzapple, M., Ladisch, M. R., Lee, Y. Y., 2005. Coordinated development of leading biomass pretreatment technologies.Bioresour. Technol. 96, 1959-1966.

Yang, B, and Wayman, C. E., (2006) BSA Treatment to enhance Enzymatic Hydrolysis of Cellulose in Lignin Containing Substrates, Biotech. And Bioengg., 94(4), 611-617.

Yang, B. and Wyman, C.E., 2008. Pretreatment: the key to unlocking low-cost cellulosic ethanol, Biofuels Bioprod. Bior., 2, pp. 26-40.

Zhang, M., Su, R., Qi, W. and He, Z., 2009. Enhanced enzymatic hydrolysis of lignocellulose by optimizing enzyme complexes, Appl. Biochem. Biotechnol., 160(5):1407-14.

Zhang, Y.H., Ding, S. Y., Mielenz, J. R., Cui, J. B. , Elander, R. T., Laser, M., Himmel, M. E., McMillan, J. R., Lynd, L. R. 2007. Fractionating recalcitrant lignocellulose at modest reaction conditions, Biotechnol. Bioeng., 97(2):214-23. 


\title{
CHAPTER 2. MECHANO-ENZYMATIC PRETREATMENT OF HARD MAPLE (ACER SACCHARUM MARSH.)
}

\author{
To be submitted to Bioresourse Technology \\ Authors: Bibu Philip George and Benjamin Dawson-Andoh
}

\begin{abstract}
Although extensive studies are conducted on cellulase enzymes to increase their rate of digestibility of lignocellulosic biomass, it is not only influenced by the ability of the enzymes but also chemical, physical and morphological characters of heterogeneous lignocellulosic biomass. Various pretreatment methods were developed in past few decades which involved the complete demolition of the cell wall or using toxic chemicals viz. concentrated acids and ammonia. In this study, a two-stage pretreatment is used to enhance the activity of cellulase by opening up more accessibility to the polysaccharides. The first stage involves the wet milling of hard maple wood to particulate size between $10 \mu \mathrm{m}-30 \mu \mathrm{m}$ and the second stage is an enzymatic depolmerisation of the substrate using six enzymes at their respective factory recommended conditions. The study shows that the treatments that were treated with pectinase, ferulic acid esterase and endoglucanase had the highest amount of sugars produced (22.65\%). The particle size analysis also showed that there was a significant amount of digestion of the substrates as the particle size significantly reduced to $0.1 \mu \mathrm{m}-1 \mu \mathrm{m}$ and $1 \mu \mathrm{m}-20 \mu \mathrm{m}$. The results also suggest that the addition of CDTA (1,2-Cyclohexylenedi nitrilo-tetraacetic Acid) and BSA (Bovine Serum Albumin).into the reaction mixture also increased the yield of sugars during the enzyme hydrolysis. HPLC (High Performance Liquid Chromatography) analysis confirms the enzyme hydrolysis by the presence of Glucose and Xylose after the reaction.
\end{abstract}




\subsection{Introduction}

Biochemical biorefinery using lignocellulosic biomass as feedstock targets D-glucose and other monomeric sugars present in the lignocellulose cell wall biopolymers. These sugars are either fermented downstream to biofuels or converted to fine chemicals (lactic acid, succinic acid, etc.). The lignocellulose cell wall whose constituent primary biopolymers are cellulose, lignin, hemicelluloses and pectin, is a complex nanocomposite which functions both as a physical and/or a chemical barrier to foreign pathogens. Foreign microbial pathogens attack lignocelluloses cell wall through the production of extracellular enzymes. For this attack to be successful, the cell wall has to be breached. Likewise, the cell wall needs to be disrupted to enable cellulase enzyme systems in biochemical refinery platform to gain access to the cellulose biopolymer in the cell wall.

Therefore, the lignocellulosic cell wall is a major hurdle that needs to be disrupted for biochemical refinery to be successful. This hurdle is generally called "recalcitrance". To-date, removal of recalcitrance of cell wall has been achieved largely by empirical methods. These methods largely depend upon the "demolition" of the cell wall. Many of these processes require large energy expenditure (e.g. steam explosion); the use of acids (sulfuric acid) or bases (ammonia) and or with oxidants (hydrogen peroxide). Collectively, these methods are called "pretreatment" and those in use today are usually some permutation and combination of these methods. Many of these methods produce "small molecules" as by-products which inhibit downstream processes. Pretreatment is an important step in biochemical biorefinery and a major cost center for biochemical biorefinery platform. Any improvement in the efficacy and reduction 
in the cost of the pretreatment process will significantly impact the overall cost of biochemical biorefinery.

An important key to the development of more efficient pretreatment methods is the elucidation of the supramolecular structure of the lignocelluloses biomass cell wall. The last decade has seen some important progress made in our understanding of the lignocelluloses cell wall (Himmel and Pivataggio, 2008). This new knowledge of the supramolecular structure of lignocellulosic cell strongly underpins the approach adopted in this study to the development of new pretreatment.

The lignocellulosic cell wall is a complex network of biopolymers- cellulose, hemicelluloses, lignin, pectin, glycosylated proteins, micromolecules (extractives, smaller molecules extractable by water and organic solvents) and inorganics such as calcium and boron. Cellulose is a biopolymer with unbranched $\beta(1 \rightarrow 4)$ - D-glucopyranosyl units while hemicelluose represents a group of heterogeneous non-linear $(1 \rightarrow 4)$ - $\beta$-linked-D-amorphous polysaccharides. Pectins and proteins also form an integral component of the cell wall structure. Pectins are cross-linked by calcium and boron ions. Structural proteins which constitute about $10 \%$ by dry weight of the primary cell wall are of three types: hydroxyl-rich proline rich proteins (HRGPs), proline-rich proteins (PRPs) and glycine-rich proteins (GRPs). Two models of primary cell wall have been proposed. Generally, the primary cell wall consists of a network of cellulose microfibrilshemicelluose enmeshed in a gel of pectin. In one model, cellulose microfibrils are tethered by surface coating of hemicelluloses (xyloglucan). This cellulose-hemicellulose network is largely (70\% approximately) responsible for the total strength of the primary wall (Cosgrove, 1999). 
Therefore, this network can be partially broken down by hydrolysis of the hemicelluloses. In the second model, cellulose microfibrils are bound by hemicellulose which is embedded in pectin. The space between cellulose microfibrils is filled by pectin. As a result, using this model, the network can be broken using pectin degradation methods.

In this study, three elements, physical size reduction of lignocelluloses biomass (using wet attrition mill), cell wall "deconstruction" enzymes applied sequentially to selectively "deconstruct" the cell wall biopolymers and a calcium chelator [1,2-Cyclohexylenedi nitrilotetraacetic Acid, CDTA] to disrupt the pectin-calcium complexes and enhance its breakdown by polygalacturonase enzyme are studied (Green et al. 1996).

The overall objectives of this study were to evaluate the efficacy of treatments that combined wet attrition milling (size reduction), a calcium chelator and selective cell wall deconstruction enzymes applied sequentially on the yield of total sugars released after treatment with the commercial cellulase enzyme, Accelerase ${ }^{\mathrm{TM}} 1000$.

\subsection{Experimental design}

Two sets of experiments were carried out to study the effect of the CDTA and Bovine Serum Albumin (BSA) on the amount of sugar produced at the end of the reaction. The experiment was carried out as a $6 \times 6$ factorial design with three replicates. The factors used in both sets were the six deconstruction enzymes and the response variable measured was the amount of sugars 
released after each enzyme treatment. At the end of the reaction, every treatment was treated with Accelerase ${ }^{\mathrm{TM}}$ 1000. A schematic representation of the experiment is shown in Figure 2.1.

\subsubsection{Materials and methods}

\subsubsection{Materials}

\subsubsection{Lignocellulose biomass}

Hard maple wood specimens were obtained from trees cut from West Virginia University Research Forest, Coopers Rock, located about 12 kilometers from Morgantown, WV. The trees were on average $10 \mathrm{~m}$ high and $200-300 \mathrm{~mm}$ in diameter at breast height. The specimens were air-dried at room temperature for 10 days and milled using a standard laboratory Wiley Mill to 35 mesh size $(0.5-2 \mathrm{~mm})$. The milled wood specimens were oven-dried at $40^{\circ} \mathrm{C}$ for 12 hours and kept in air tight containers between $5 \%$ to $8 \%$ moisture content until used.

\subsubsection{Lignocellulose cell wall deconstruction enzymes}

Six deconstruction enzymes used in this study were pectinase (multifect pectinase FE, Genencore International, Rochester, New York), proteinase (Promod 523P - P523P/2500, Biocatalysts, Wales, UK), ferulic acid esterase (Depol 740L, Biocatalysts, Wales, UK), polyglacturonase (pectinase 162L-P162L, Biocatalysts, Wales, UK), xylanase (Depol 761P D761P, Biocatalysts, Wales, UK), and endoglucanase (Celluclast 1.5L FG, Novozymes,

Franklinton, NC), followed by Accelerase ${ }^{\mathrm{TM}} 1000$ (Genecore International Inc., Rochester, NY). 


\subsubsection{Chelators and other materials}

1,2-Cyclohexylenedi-nitrilo-tetraacetic acid (CDTA, HACH Company, Loveland, CO., Cat. 7007-26) was used as calcium chelator and Bovine Serum albumin (98\%, BSA, Sigma Aldrich, Cat. No A7906 St. Louis, MO) was employed as an enzyme stabilizer).

\subsubsection{Methods}

\subsubsection{Wet Attrition milling of hard maple}

The initial particle size of oven-dried Wiley-milled milled hard maple wood was measured microscopically and soaked in sodium hydroxide solution $(0.5 \% \mathrm{w} / \mathrm{v})$ for $24 \mathrm{hrs}$. One hundred and fifty grams of sodium hydroxide-treated hard maple wood specimens was wet-milled for 6 hours at 600 RPM in a Union Process Lab Attritor Mill (Model 01-HD/01-HDDM, Akron, OH, USA). The Attritor Mill was fitted with a $750 \mathrm{~mL}$ capacity aluminum oxide (aluminum oxide, $\mathrm{Al}_{2} \mathrm{O}_{3}$ ) tank, containing grinding media of $5 \mathrm{~mm}$ diameter zirconium oxide beads (to avoid aluminum contamination). The tank was maintained at $30{ }^{\circ} \mathrm{C}$ by means of external thermostated water bath. During milling, when the slurry became too viscous for processing, additional $\mathrm{NaOH}$ was added as required. Presence of any sugars in the milled slurry was determined by 3,5Dinitrosalicylic acid (DNS) assay.

\subsubsection{Chemical analysis of untreated and pretreated hard maple wood}

The total amount of soluble and insoluble lignin present in hard maple was determined as per a modification of the standard NREL method (Sluiter et al., 2008). To two hundred mg of milled 
hard maple wood in a $100 \mathrm{ml}$ test tube, $3 \mathrm{ml}$ sulfuric acid $\left(\mathrm{H}_{2} \mathrm{SO}_{4}, 72 \%\right.$ weight/volume, w/v) at room temperature was added and vortexed frequently for 2-3 hours. At the end of this period, the reaction mixture was diluted with $112 \mathrm{ml}$ of deionized water and autoclaved at $121^{\circ} \mathrm{C}$ for 20 minutes to hydrolyze the carbohydrates. The resulting solution was filtered through pre-weighed oven dry sintered ceramic crucible. The filtrate was used to determine total sugars as per the DNS assay (Miller, 1959). To determine the acid soluble lignin content, the absorbance of the filtrate at 240nm was measured using a UV-visible spectrophotometer (Sluiter et al., 2008). The residue, insoluble lignin was oven-dried at $103 \pm 2{ }^{\circ} \mathrm{C}$, allowed to cool in a desiccator and weighed. The oven-dried weights of insoluble lignin were used to determine lignin content as per Sluiter's formula (Sluiter et al., 2008):

$\%$ ASL $=\left(\frac{\text { UVabs } \times \text { Volume } \times \text { Dilution }}{\epsilon \times \text { ODWsample }}\right) \times 100$

where:

UVabs $=$ average UV-Visible absorbance for the sample at $240 \mathrm{~nm}$

Dilution $=\frac{\text { Sample Volume }+ \text { Diluting solvent volume }}{\text { Volume of sample }}$

$\varepsilon=$ Absorptivity of lignin at 240nm,

The amount of inorganics (ash) present in milled wood specimens was determined as per the ASTM standard protocol ASTM E 1534 - 93. 


\subsubsection{Analysis of particles by Light Scattering Particle Size Analysis, Cold Field Emission Gun Scanning Electron Microscopy (FCEGSEM) and Image Analysis.}

The distribution of wood particle size was measured using a MicrotracS3000/S3500 Particle Size Analyzer (Montgomeryville, PA, USA) before and after milling. For milled specimens, the water slurry of milled wood was sonicated just before each measurement. Two hundred milligram of slurry was added to deionized water; vortexed and filtered. The filtrate was analyzed as per the DNS assay for sugar content using D-glucose as standard. Additionally, the size and morphology of milled-wood specimens were analyzed by Scanning Electron Microscopy (SEM). One hundred milligram of Attritor milled-wood was diluted with 50ml of deionized water. A drop of this solution was smeared as a thin film on a glass side; allowed to air-dry; sputter coated in gold; and examined under a Hitachi S-4700 Cold Field Emission Gun Scanning Electron Microscope (FCEGSEM) at $5 \mathrm{kV}$.

For image analysis, a smear of the diluted wet-milled specimen in deionized water was placed on a neat glass slide and photos of different fields containing the wood particles were taken. The photos were analyzed using Nikon Eclipse E600 microscope at a magnification of 1000X. The photos were taken by means of an attached DXM 1200 Digital Eclipse camera system. The acquired images were processed by ACT-1 software (Manufacturer, city, country). The acquired images were processed to gray scale for image analysis using Image $\mathbf{J}$ software (Version 38, manufacturer, city, country). 


\subsubsection{Sequential enzymatic depolymerization of wood cell wall to remove recalcitrance}

Sodium hydroxide pre-treated Attritor-milled hard maple wood specimen was subjected to sequential treatment of seven cell wall depolymerizing enzymes as per a factorial experimental design (Figure not shown). Each factor was evaluated at triplicate levels.

Wet-milled wood was made to a concentration of $7 \%(\mathrm{w} / \mathrm{v})$ in a sodium acetate buffer $(\mathrm{pH} 5.0)$ in $20 \mathrm{ml}$ reaction mixtures. They were subjected to two treatments. One set of treatment contained 1\%(w/v) BSA and 5mM CDTA and another set (control) lacked these two reactants. Each treatment group was subjected sequentially to the test cell-wall depolymerizing enzymes: pectinase (multifect pectinase FE, Genencore International, Rochester, New York), proteinase (Promod 523P - P523P/2500, Biocatalysts, Wales, UK), ferulic acid esterase (Depol 740L, Biocatalysts, Wales, UK), polyglacturonase (pectinase 162L-P162L, Biocatalysts, Wales, UK), xylanase (Depol 761P - D761P, Biocatalysts, Wales, UK), and endoglucanase (Celluclast 1.5L

FG, Novozymes, Franklinton, NC). At the end of each sequential treatment, Accelerase ${ }^{\mathrm{TM}} 1000$ (Genecore International Inc., Rochester, NY), a commercial cellulose hydrolyzing enzyme, was added to liberate D-Glucose from accessible cellulose in wood cell wall. Reaction time for each enzyme assay was 2 hours. Details of the reaction mixture and duration of the reaction are listed in Table 2.1.

Total amount of sugars produced by each enzyme treatment was measured using DNS assay with D-glucose as a standard. Percentage of wood converted to sugars was calculated taking the total amount of substrate present in the reaction mixture as $1400 \mathrm{mg}(7 \% \mathrm{w} / \mathrm{v}$ in $20 \mathrm{ml})$. While the percentage of holocellulose converted was calculated as follows. 
$\%$ of holocellulose converted $(\mathrm{mg})=\left(\frac{\text { Total Sugars }(\mathrm{mg})}{\text { Total Holocellulose }(\mathrm{mg})}\right) * 100$

Distribution of milled-wood particle size after enzymatic treatment was again measured by Image analysis using Microtract-S3000/S3500 particle size analyzer. Treatments that required minimum number of cell wall-depolymerizing enzymes to produce significantly higher amount of sugars per treatment were selected for the post-treatment image analysis.

\subsubsection{Analysis of sugars by Dinitrosalyclic acid assay and High Performance Liquid Chromatography}

Monosaccharides produced were analyzed by DNS assay to determine total sugars using Dglucose as standard. The types of sugars produced were determined by High Performance Liquid Chromatography (HPLC) analysis using D-glucose and D-xylose as standards. The HPLC System (Waters 2695, Waters Corp., Milford, MA) consisted of Waters Sugar-Pack I column (6.5 x 300 mm, Particle size $10 \mu \mathrm{m}$ [WAT085188], Waters Corp., Milford, MA) and a Waters Refractive Index detector 2414 (Waters Corp., Milford, MA). The Sugar-Pack I column was protected with a Guard-Pak (Waters Corp., Milford, MA).

The specimen solution for analysis was prepared by first filtering through a membrane filter (pore size of $0.45 \mu 1$, Whatman $-6870-2504$, Piscataway, NY) fitted to a $25 \mathrm{~mm}$ syringe. Ten $\mu \mathrm{l}$ aliquot was pipetted into a sample vial and placed in the HPLC's sample carousel. A linear 
gradient of deionized water at a flow rate of $0.20 \mathrm{ml} / \mathrm{min}$ was used to elute the sugars in the test solution.

\subsection{Results and discussion}

Hard maple used in this study contained $70.34 \pm 0.2$ of holocellulose (hemicelluloses and cellulose on D-glucose basis), $20.73 \pm 0.45$ of lignin and $4.23 \pm 0.41$ of inorganics (all on \% ovendry weight basis), similar to earlier results of Mitchell et al. (1948).

Microscopic analysis of Wiley-milled hard maple particles at 400X magnification showed that the average dimension was approximately 100 micrometer. Wet-milling in sodium hydroxide by Attritor miller produced viscous, light colored slurry. Analysis of wet-milled wood by DNS assay of wet-milled wood confirmed the absence of monosaccharide sugars, an indication that wet-milling alone did not produce monosaccharides from the holocellulose.

Dimensions (Figure 2.5a) of wet-milled hard maple wood particles as determined by Microtrac analysis ranged from $1 \mu \mathrm{m}$ to $100 \mu \mathrm{m}$. Statistical distribution of particle size showed a normal distribution with $95 \%$ of particles between $10 \mu \mathrm{m}-30 \mu \mathrm{m}$ range. This was confirmed by Image analysis using the image $\mathbf{J}$ software (Wayne Rasband, National Institute of Health, USA). This method showed the average dimensions of hard maple particles to be $19.75 \pm 3.94 \mu \mathrm{m}$. These dimensions were confirmed by SEM (Hitachi S-4700 Cold Field Emission Gun Scanning Electron Microscope, FEGSEM) analysis and also demonstrated that the wood particles varied in 
shape from circular to rectangular. Further, SEM analysis demonstrated that attrition milling reduced the size of Willey-milled wood hard maple particles from 100micrometer to1 $\mu$ m (Figure $2.5 \mathrm{c})$.

Two-way Analysis of Variance (ANOVA) showed that total sugars produced by BSA and CDTA treated samples were higher than the controls $(\mathrm{p}=0.001)$. Treatments lacking BSA and CDTA produced a minimum total sugars yield of $3.47 \%$ after Accellerase ${ }^{\circledR} 1000$ treatment. Total sugar yields of $15.41 \%$ was obtained for treatments subjected sequentially to ferulic acid esterase, polyglacturonase, xylanase followed terminally by Accellerase ${ }^{\circledR} 1000$ (Table 1.2, Figure 2.2). Treatment 9 which consisted of polygalacturonase and endoglucanase followed by Accelerase $^{\mathrm{TM}} 1000$ yielded total sugars of less than $1 \%$. The treatment containing all depolymerizing enzymes gave the highest total sugars, 28.78\%. Two treatments, 6 and 10 (Table 2.3, Figure 2.3) subjected to less the maximum number of cell wall depolymerizing enzymes produced relatively high total sugars, 22.65 and $24.69 \%$ respectively. Treatment 6 consisted of sequential treatment with three cell wall depolymerizing enzymes: pectinase, ferulic acid esterase and endoglucanase and treatment 10 also consisted of four cell-wall depolymerizing enzymes: pectinase, polyglacturonase, xylanase and endoglucanase.

The use of proteinase enzyme did not enhance hydrolysis of holocellulose without pre- treatment with CDTA and BSA. The latter two enhanced enzymatic hydrolysis and produced a total sugar yield of $16 \%$ for both treatments 6 and 10. High Performance Liquid Chromatography of all treatment hydrolysates showed D-glucose and xylose as the main free sugars (Figure 2.4a, b, c). 
A two-factor ANOVA analysis of total sugars produced by treatments containing CDTA and BSA and control showed significant effect for CDTA and BSA $(p=0.001)$.

Increased pectinase activity was observed for both treatments 6 and 10 (Table 2.3, Figure 2.3). Both contained CDTA and the observed enhanced pectinase activity might be due to the calcium sequestration effect of CDTA. The latter sequesters $\mathrm{Ca}^{2+}$ from pectin in the cell wall and opens up the cell-wall to increasing access of depolymerizing enzymes by peeling open the junction zones between pectin molecules held by $\mathrm{Ca}^{2+}$ cations (Wehr et al., 2004). Even though the use of ferulic acid esterase and polyglacturonase (pectinase 162L-P162L) had the same sugar yield, the use of polyglacturonase increased the action of the subsequent enzymes while ferulic acid esterase did not (Table 2.3). We propose that Pectinase 162L-P162L hydrolyzed pectin in the primary cell wall to open it up and enhanced access of other enzymes applied sequentially to depolymerize biopolymers of the cell wall.

Particle size analysis (Fig. 2.5b) and image analysis (data not shown) showed that particle size of wood decreased significantly after the enzymatic treatment. Two dimensiom ranges of particle sizes were observed: (1) 0.1 to $1 \mu \mathrm{m}$ and (2) 1 to $20 \mu \mathrm{m}$ (Figure $2.5 \mathrm{a} \& \mathrm{~b}$, image analysis data not shown).

Overall, these results confirm that of earlier studies that enzymatic hydrolysis of lignocelluosic substrates reduces their particle size (Neilson et al., 1982, Mais et al., 2002, Ryu and Lee, 1983). 
However, in this study different substrates have different conversion rates due to the inhibitory action of the end products or the by production of the enzymatic hydrolysis. This study also confirms that wet-attrition-milling of wood particles is a reductive process. This process reduced wood particle size to $10 \mu \mathrm{m}-30 \mu \mathrm{m}$ range with attendant increase in surface to volume ratio. This process subsequently increases the depolymerizing activity of the enzymes in wood polymers. In the same study, a considerable amount of xylose was released by hydrolysis of holocellulose for treatment 10 was confirmed by HPLC analysis of sugars.

Several past studies have shown that CDTA and BSA increase the accessibility of cell wall depolymerizing enzymes (Green et al., 1996, Yang \& Wyman, 2006). In plant cell walls, the compound middle lamella contains calcium salts of pectic substances. CDTA chelates the $\mathrm{Ca}^{2+}$ in the pectin without degrading the galacturonan chains thereby increasing the efficiency of pectinase enzyme to act on pectin. Since polyglacturonase enzymes hydrolyze pectic acid by splitting glycosidic linkages adjacent to free carbonyl groups, it is very critical to remove the $\mathrm{Ca}^{2+}$ ions for effective hydrolysis of pectins (Voragen et al., 1995). The results of this study shows that the accessibility of Accellerase ${ }^{\circledR} 1000$ enzyme to the holocellulose in the cell wall was increased by the action of CDTA. Bovine Serum Albumin acts by adsorbing competitively and irreversibly lignin and prevents its adsorbition and inactivation of cellulase enzyme (Yang \& Wyman, 2006, Kawamoto et al, 1992).

To-date, traditional pretreatment methods for lignocellulosic biomass to remove recalcitrance include physical or mechanical, chemical, or both physicochemical and biological protocols. 
Teymouri et al. (2005) reported that on ammonia fiber expansion (APEX) treatment on corn stover with concentrated $\mathrm{NH}_{3}$ as the catalyst followed by enzymatic hydrolysis produced $96 \%$ glucose and $76 \%$ xylose of the washed material, corresponding to a glucan concentration of $1 \mathrm{wt}$ $\%$ after $168 \mathrm{hr}$ with 15FPU/g cellulose. Other classical pretreatment methods have produced high total sugar yields: ARP (90\%), dilute acid hydrolysis (91\%), Steam explosion (90\%), Liquid hot water treatment $(85 \%)$ and wet oxidation $(74 \%)$ that showed similar results having excellent substrate conversion rates (Dale \& Moreira, 1982, Wyman et al., 2005, Kalman et al., 2002, Lloyd et al., 2005,and Öhgren et al., 2005). But all these techniques either use hazardous materials (strong acids or bases) or use high amount of energy input to convert the desired substrates or lignocellulosic materials into sugars.

The method evaluated in this study has advantage over the conventional methods in using nonhazardous material and lesser energy input when compared. This study sought to determine if physical methods and sequential application of cell wall deconstruction enzymes can be used as pretreatment. This study was presented with a number of challenges: (1) optimized order of sequential application of cell-wall depolymerizing enzymes was unknown and future studies need to evaluate this; (2) the relative concentrations of the depolymerizing enzymes on cell-wall depolymerization; (3) potential synergistic interactions of these enzymes depending upon their position in the sequence

Thus, future follow-up studies will study the effect of sequence of cell-wall depolymerizing enzymes and optimize the process using the set of depolymerizing enzymes that had performed well in this study. 


\subsection{Conclusion}

This study demonstrated that physical attrition process reduced the size of wood particles and enhanced the action of depolymerizing enzymes on the hydrolysis of holocellulose in the biomass cell wall. Bovine Serum Albumin and CDTA increased the hydrolysis of cell wall biomass. Treatments 6 and 10 represent treatments with less than the maximum number of cellwall depolymerizing enzymes that produced the highest total sugar yields.

These preliminary results demonstrate the potential viability of this approach. These results are a indicative of the viability this concept. Future follow-up studies should seek to optimize the order of best performing cell-wall depolymerizing enzymes using the depolymerzing enzymes which performed well are required to optimize this approach the sequence of these enzymes and their respective concentrations. 
Table 2.1. Details of sequential enzymatic treatment of the biomass using seven cell wall depolymerizing enzymes.

\begin{tabular}{|l|l|l|l|}
\hline $\begin{array}{l}\text { Enzymes used for the } \\
\text { treatment }\end{array}$ & $\begin{array}{l}\text { Dosage } \\
\%\end{array}$ & $\begin{array}{l}\text { *Dosage for } 7 \% \text { biomass in } 20 \mathrm{ml} \\
\text { reaction mixture }(\mu \mathrm{l})\end{array}$ & $\begin{array}{l}\text { Temperature } \\
{ }^{\circ} \mathrm{C}\end{array}$ \\
\hline Pectinase (PEC) & 2 & 28 & 50 \\
\hline Proteinase (PRO) & 0.67 & 9.38 & 55 \\
\hline $\begin{array}{l}\text { Ferulic Acid Esterase } \\
\text { (FAE) }\end{array}$ & 20 & 280 & 50 \\
\hline $\begin{array}{l}\text { Polygalacturonase (POL) } \\
\text { Xylanase (XYL) }\end{array}$ & 2 & 28 & 50 \\
\hline Endoglucanase (END) & 2 & 28 & 50 \\
\hline Accellerase 1000 (ACC) & 12 & 168 & 50 \\
\hline
\end{tabular}

*Dosage as per manufacturer's recommendation 
Table 2.2. Showing details of the amount of sugars produced after each enzymatic treatment without BSA and CDTA in the reaction mixture.

\begin{tabular}{|c|c|c|c|c|c|c|c|c|c|c|c|}
\hline \multirow{3}{*}{ S1 No } & \multicolumn{9}{|c|}{ Sugars produced after enzymatic treatment g/L (Mean) } & \multirow{3}{*}{$\begin{array}{l}\text { \%of } \\
\text { conversion } \\
\text { (wood) }\end{array}$} & \multirow{3}{*}{$\begin{array}{l}\text { \%of } \\
\text { conversion } \\
\text { (holocellulose) }\end{array}$} \\
\hline & \multirow{2}{*}{ PEC } & \multirow{2}{*}{ PRO } & \multirow{2}{*}{ FAE } & \multirow{2}{*}{ POL } & \multirow{2}{*}{ XYL } & \multirow{2}{*}{ END } & \multirow{2}{*}{$\mathrm{ACC}$} & \multicolumn{2}{|c|}{$\begin{array}{l}\text { Tot. Sugars } \\
(\mathrm{mg})\end{array}$} & & \\
\hline & & & & & & & & $\mu$ & $\begin{array}{l}\text { S. Dev. } \\
\pm\end{array}$ & & \\
\hline 1 & $\mathrm{X}$ & $\mathrm{X}$ & $\mathrm{X}$ & $\mathrm{X}$ & $\mathrm{X}$ & $\mathrm{X}$ & 0.034 & 34 & 0.06 & 2.43 & 3.47 \\
\hline 2 & 0.013 & $\mathrm{X}$ & $\mathrm{X}$ & $\mathrm{X}$ & 0.016 & $\mathrm{X}$ & 0.027 & 41 & 0.03 & 2.93 & 4.18 \\
\hline 3 & $\mathrm{X}$ & 0.003 & $\mathrm{X}$ & $X$ & 0.041 & 0.005 & 0.014 & 16 & 0.02 & 1.14 & 1.63 \\
\hline 4 & 0.006 & 0.024 & $X$ & $X$ & $X$ & 0.024 & 0.006 & 54 & 0.05 & 3.86 & 5.51 \\
\hline 5 & $X$ & $X$ & 0.026 & $X$ & 0.002 & 0 & 0.059 & 60 & 0.02 & 4.29 & 6.12 \\
\hline 6 & 0.011 & $X$ & 0.023 & $X$ & $X$ & 0.024 & 0.029 & 70 & 0.04 & 5.00 & 7.14 \\
\hline 7 & $X$ & 0.029 & 0.027 & $X$ & $X$ & $X$ & 0.024 & 31 & 0.03 & 2.21 & 3.16 \\
\hline 8 & 0.012 & 0.023 & 0.031 & $X$ & 0.021 & $X$ & 0.016 & 76 & 0.02 & 5.43 & 7.76 \\
\hline 9 & $X$ & $X$ & $X$ & 0.009 & $X$ & 0.006 & 0.006 & 9 & 0.01 & 0.64 & 0.92 \\
\hline 10 & 0.009 & $X$ & $X$ & 0.021 & 0.019 & 0.014 & 0.016 & 79 & 0.02 & 5.64 & 8.06 \\
\hline 11 & $X$ & 0.004 & $X$ & 0.006 & 0.002 & $\mathrm{X}$ & 0.048 & 49 & 0.03 & 3.50 & 5.00 \\
\hline 12 & 0.003 & 0.003 & $X$ & 0.004 & $X$ & $X$ & 0.051 & 52 & 0.04 & 3.71 & 5.31 \\
\hline 13 & $X$ & $X$ & 0.207 & 0.002 & 0.003 & $X$ & 0.057 & 151 & 0.08 & 10.79 & 15.41 \\
\hline 14 & 0.003 & $\mathrm{X}$ & 0.055 & 0.002 & $X$ & $\mathrm{X}$ & 0.018 & 19 & 0.02 & 1.36 & 1.94 \\
\hline 15 & $X$ & 0.016 & 0.028 & 0.006 & $\mathrm{X}$ & 0.031 & 0.015 & 75 & 0.02 & 5.36 & 7.65 \\
\hline 16 & 0.009 & 0.012 & 0.036 & 0.007 & 0.014 & 0.011 & 0.015 & 91 & 0.02 & 6.50 & 9.29 \\
\hline
\end{tabular}


Table 2.3. Showing details of the amount of sugars produced after each enzymatic treatment with BSA and CDTA in the reaction mixture.

\begin{tabular}{|c|c|c|c|c|c|c|c|c|c|c|c|}
\hline \multirow{3}{*}{ S1 No } & \multicolumn{9}{|c|}{ Sugars produced after enzymatic treatment mg/L (Mean) } & \multirow{3}{*}{$\begin{array}{l}\text { \%of } \\
\text { conversion } \\
\text { of wood }\end{array}$} & \multirow{3}{*}{$\begin{array}{l}\text { \%of } \\
\text { conversion } \\
\text { (holocellulose) }\end{array}$} \\
\hline & \multirow[b]{2}{*}{ PEC } & \multirow[b]{2}{*}{ PRO } & \multirow[b]{2}{*}{ FAE } & \multirow[b]{2}{*}{ POL } & \multirow[b]{2}{*}{ XYL } & \multirow[b]{2}{*}{ END } & \multirow[b]{2}{*}{$\mathrm{ACC}$} & \multicolumn{2}{|c|}{ Tot. Sugars (mg) } & & \\
\hline & & & & & & & & $\mu$ & $\begin{array}{l}\text { S. Dev. } \\
\pm\end{array}$ & & \\
\hline 1 & $\mathrm{X}$ & $\mathrm{X}$ & $\mathrm{X}$ & $\mathrm{X}$ & $\mathrm{X}$ & $\mathrm{X}$ & 0.055 & 55 & 0.04 & 3.93 & 5.61 \\
\hline 2 & 0.034 & $\mathrm{X}$ & $\mathrm{X}$ & $\mathrm{X}$ & 0.016 & $\mathrm{X}$ & 0.058 & 109 & 0.02 & 7.79 & 11.12 \\
\hline 3 & $\mathrm{X}$ & 0.003 & $X$ & $\mathrm{X}$ & 0.041 & 0.003 & 0.040 & 44 & 0.10 & 3.14 & 4.49 \\
\hline 4 & 0.040 & 0.053 & $X$ & $X$ & $X$ & 0.051 & 0.001 & 142 & 0.06 & 10.14 & 14.49 \\
\hline 5 & $X$ & $X$ & 0.005 & $X$ & 0.002 & 0.003 & 0.115 & 117 & 0.13 & 8.36 & 11.94 \\
\hline 6 & 0.064 & $X$ & 0.058 & $X$ & $X$ & 0.058 & 0.042 & 222 & 0.02 & 15.86 & 22.65 \\
\hline 7 & $\mathrm{X}$ & 0.038 & 0.002 & $X$ & $X$ & $X$ & 0.051 & 90 & 0.06 & 6.43 & 9.18 \\
\hline 8 & 0.055 & 0.043 & 0.023 & $\mathrm{X}$ & 0.021 & $\mathrm{X}$ & 0.047 & 212 & 0.14 & 15.14 & 21.63 \\
\hline 9 & $X$ & $X$ & $\mathrm{X}$ & 0.011 & $X$ & 0.007 & 0.002 & 10 & 0.01 & 0.71 & 1.02 \\
\hline 10 & 0.066 & $X$ & $X$ & 0.059 & 0.019 & 0.036 & 0.050 & 242 & 0.01 & 17.29 & 24.69 \\
\hline 11 & $X$ & 0.011 & $X$ & 0.002 & 0.002 & $X$ & 0.098 & 102 & 0.04 & 7.29 & 10.41 \\
\hline 12 & 0.001 & 0.008 & $X$ & 0.010 & $X$ & $\mathrm{X}$ & 0.089 & 94 & 0.05 & 6.71 & 9.59 \\
\hline 13 & $X$ & $X$ & 0.003 & 0.006 & 0.003 & $\mathrm{X}$ & 0.139 & 154 & 0.05 & 11.00 & 15.71 \\
\hline 14 & 0.003 & $\mathrm{X}$ & 0.005 & 0.002 & $\mathrm{X}$ & $X$ & 0.027 & 31 & 0.02 & 2.21 & 3.16 \\
\hline 15 & $X$ & 0.035 & 0.033 & 0.034 & $X$ & 0.058 & 0.050 & 209 & 0.02 & 14.93 & 21.33 \\
\hline 16 & 0.038 & 0.028 & 0.059 & 0.037 & 0.014 & 0.037 & 0.044 & 282 & 0.09 & 20.14 & 28.78 \\
\hline
\end{tabular}




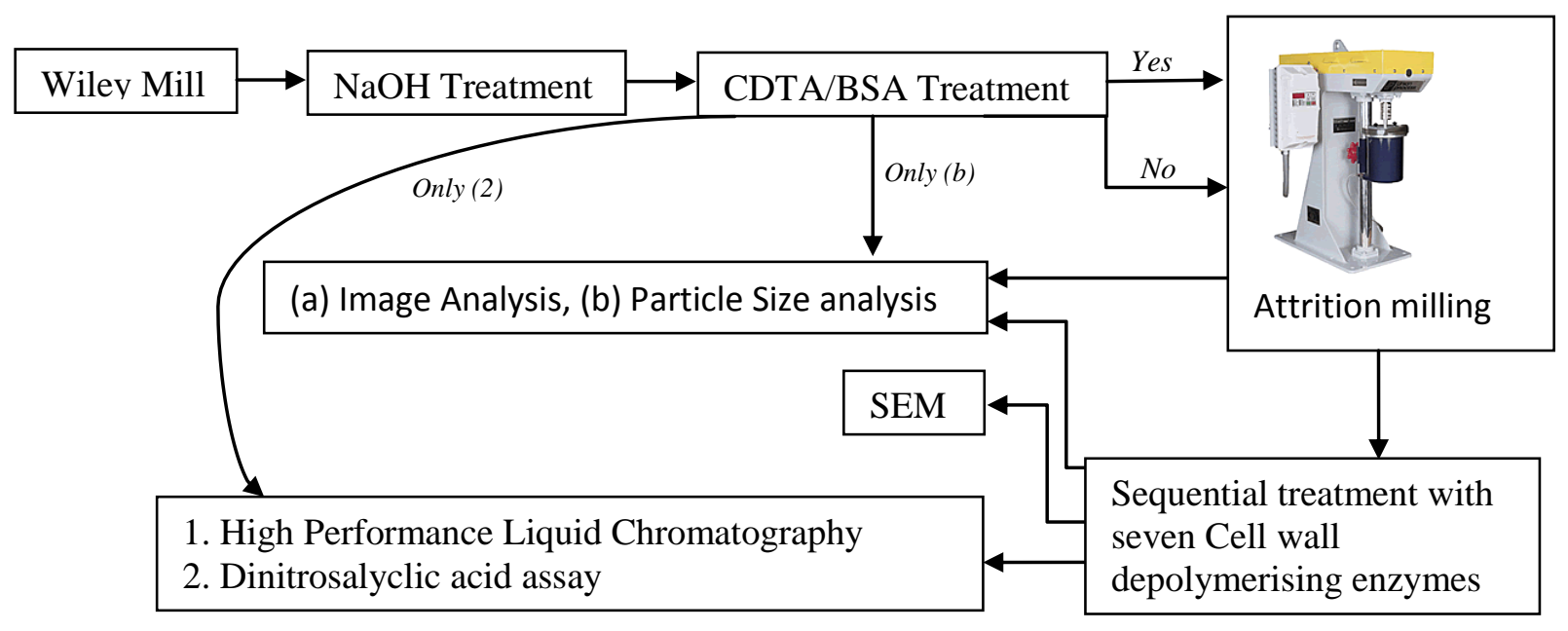

Figure 2.1. A schematic showing details of the experimental protocol used in the present study 


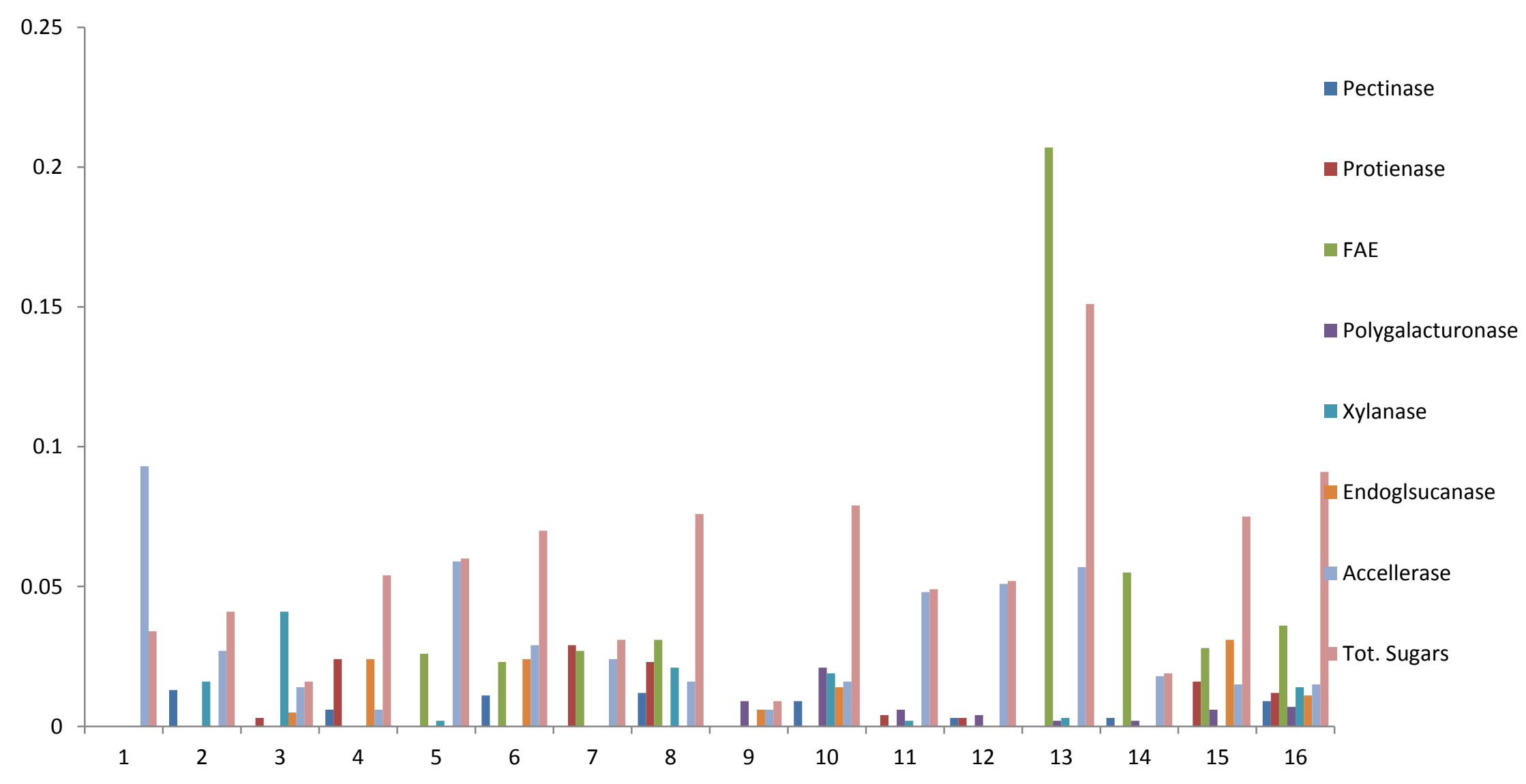

Figure 2.2. Showing details of the amount of sugars produced after each enzymatic treatment without BSA and CDTA in the reaction mixture 


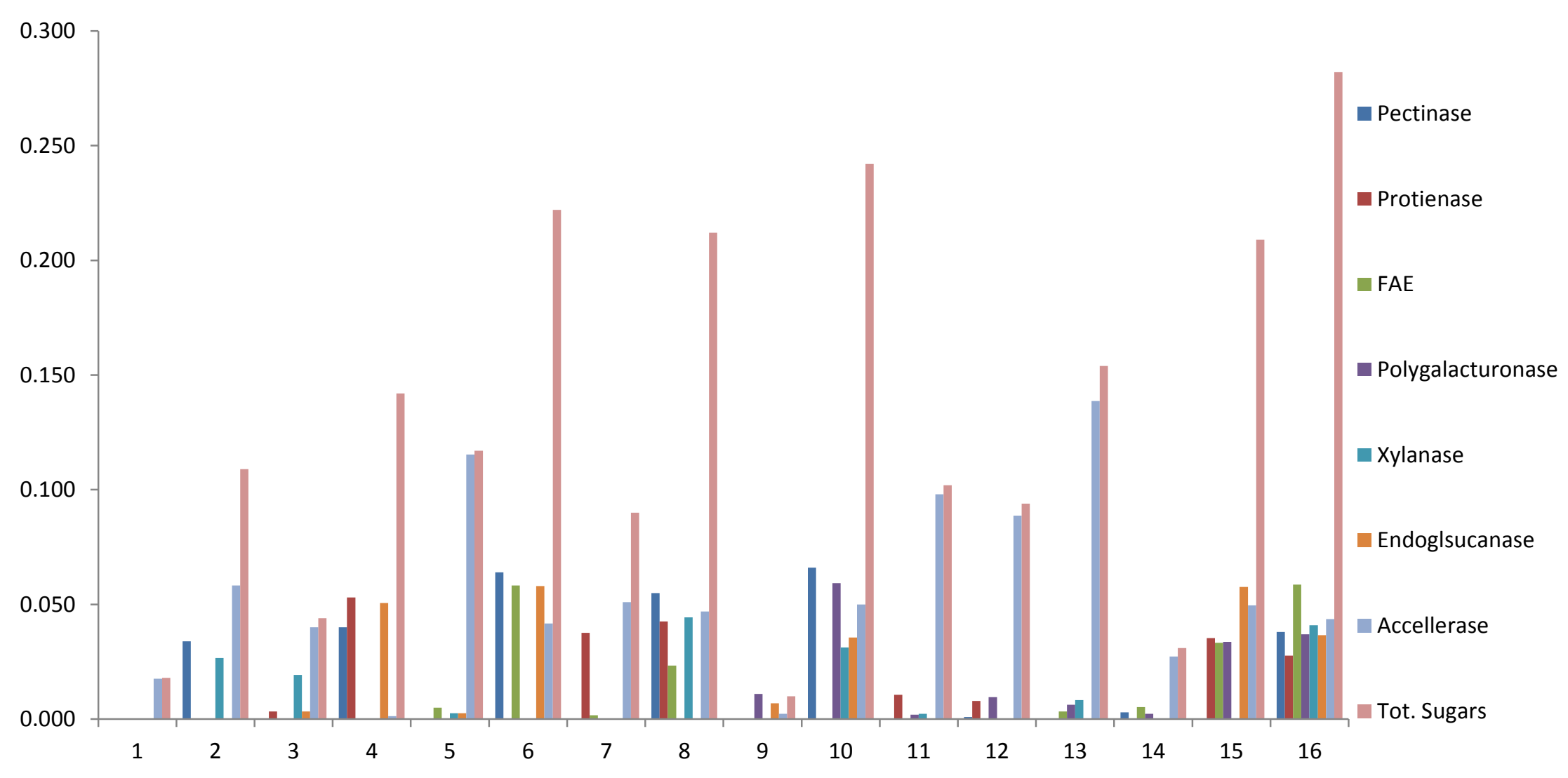

Figure 2.3. Showing details of the amount of sugars produced after each enzymatic treatment without BSA and CDTA in the reaction mixture 

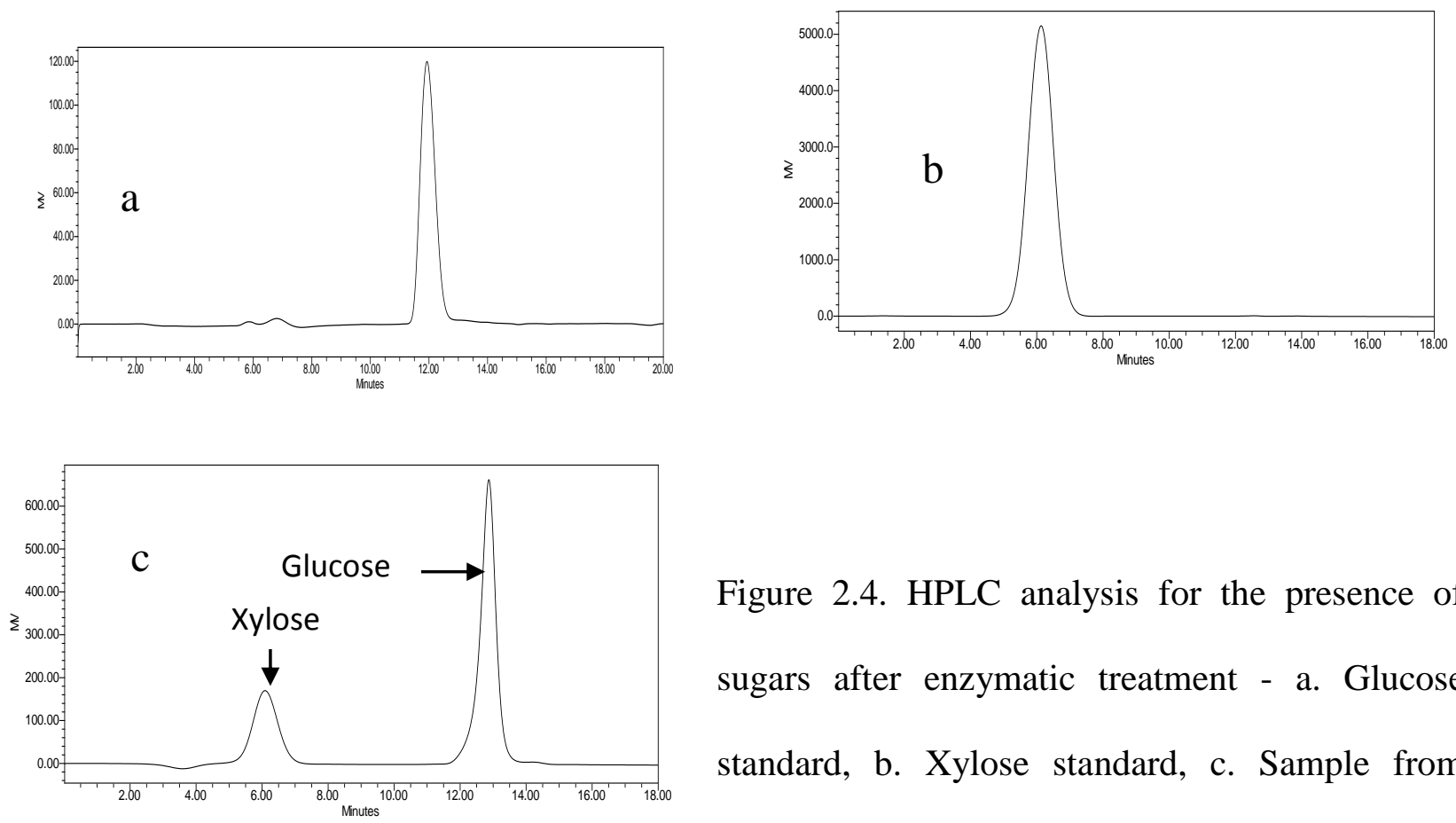

Figure 2.4. HPLC analysis for the presence of sugars after enzymatic treatment - a. Glucose standard, b. Xylose standard, c. Sample from experiment 13 with BSA \&CDTA 


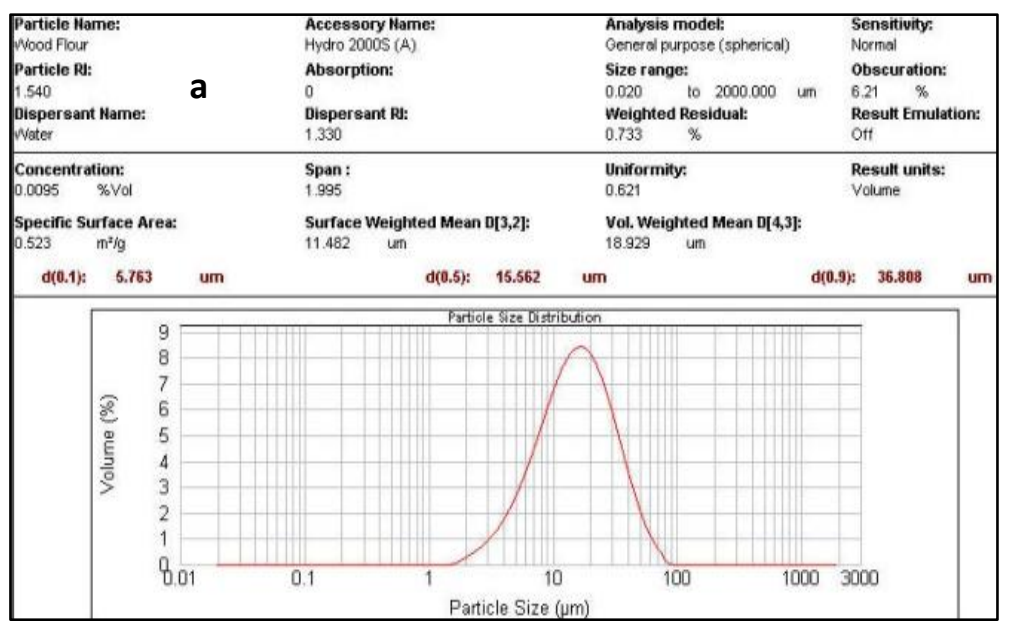

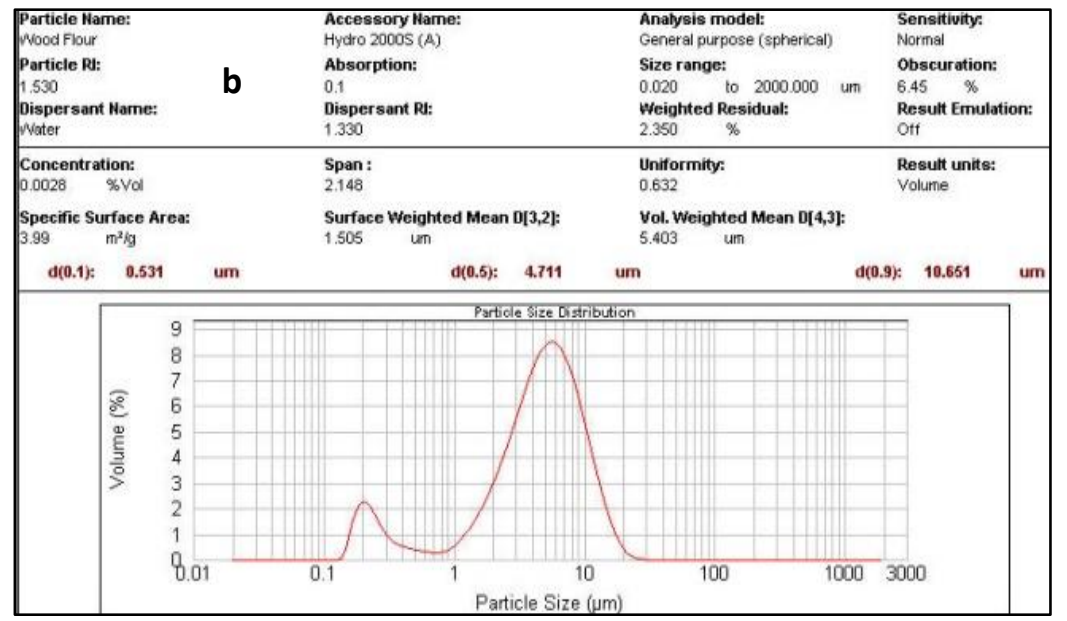

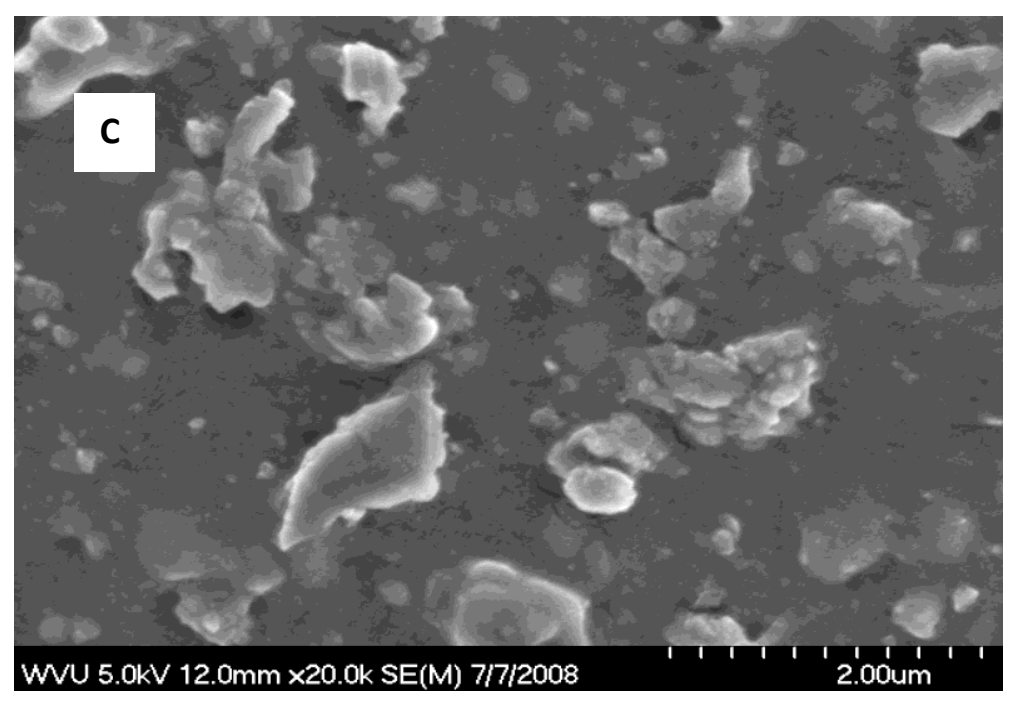

Figure 2.5. Particle size analysis after wet milling (a), after enzymatic treatment (b) and SEM of the particles after enzyme hydrolysis (c). 


\section{References}

Cosgrove, D. J., 1999. Enzymes and other Agents that Enhance Cell Wall Extensibility.Annu. Rev. Plant Physiol. Plant Mol. Biol. 50, 391-417.

Dale, B. E., Moreira, M. J. 1982. Freeze-explosion technique for increasing cellulose hydrolysis.Biotechnol.Bioeng. Symp.12, 31-43.

Green, F., Kuster, T. A., Highley, T. L., 1996. Pectin Degradation during Colonization of Wood by Brow-rot Fungi.Recent Res. Devel.in Plant Pathol., 1, 83-93.

Himmel, M. E., and Picataggio, S. K., 2008. Our Challenge is to Acquire Deeper Understanding of Biomass Recalcitrance and Conversion, in: Himmel, M. E (Eds.), Biomass Recalcitrance: Deconstructing the Plant Cell Wall for Bioenergy, Blackwell Publishing Ltd, Oxford, UK pp. 16.

Kalman G., Varga E., and Reczey K., 2002.Diluted sulphuric acid pretreatment of corn stover at long residence times. Chem. Biochem. Eng. 16(4), 151-157.

Kawamoto, H., Nakatsubo, F. and Murakami, K., 1992.Protein-adsorbing capacities of lignin samples. Mokuzai Gakkaishi. 38(1), 81-84.

Lloyd T. A., Wyman C. E., 2005. Combined sugar yields for dilute sulfuric acid pretreatment of corn stover followed by enzymatic hydrolysis of the remaining solids. Bioresour. Technol. 96, 1967-1977.

Mais, U., Esteghlalian, A. R., Saddler, J. N., Mansfield, S. D., 2002. Enhancing the Enzymatic Hydrolysis of Cellulosic materials using simultaneous Ball Milling. Appl. Biochem. And Biotechnol.. $98-100,815-832$. 
Miller, G.L., 1959. Use of Dinitrosalicylic Acid Reagent for Determination of Reducing Sugar.Anal. Chem. 31, 426-428.

Mitchell, R. L., Rogers, S. C., Ritter, G. J., 1948. Hemicelluloses from Maple Holocellulose Yield and Composition.Ind. and Engg. Chem. 40(8), 1528 - 1529.

Neilson, M. J., Kelsey, R. G., Shafizadeh, F., 1982.Enhancement of Enzymatic Hydrolysis by Simultaneous Attrition of Cellulosic Substrates.Biotechnol.and Bioengg. 24, 293 - 304.

Öhgren, K., Galbe, M., Zacchi, G., 2005.Optimization of Steam Pretreatment of SO2Impreganted Corn Stover for Fuel Ethanol Production. Appl. Biochem. and Biotech. 121, 10551068.

Ryu, S. K., Lee, J. M., 1983. Bioconversion of Waste Cellulose by Using an Attrition Bioreactor.Biotechnol.and Bioengg. 25, pp. $53-65$.

Sluiter, A, Hames, B., Ruiz, R., Scarlata, C., Sluiter, J., Templeton, D., Crocker, D., 2008. Technical Report, National Renewable Laboratory. NREL/TP-510-42618. Available from http://www.nrel.gov/biomass/pdfs/42618.pdf

Teymouri, F., Laureano-Perez, L., Alizadeh, H., Dale, B.E., 2005.Optimization of the ammonia fiber explosion (AFEX) treatment parameters for enzymatic hydrolysis of corn stover.Bioresour. Technol. 96, pp. 2014-2018.

Voragen, A. G. J., Pilnik, W., 1995. Pectins, in: Stephen, A. M. (Ed.), Food Polysaccharides and their Applications, Marcel Dekker Inc., New York, pp. 287-339.

Wehr, J.B., Menzies, N.W., Blamey, F.P.C., 2004. Inhibition of cell-wall autolysis and pectin degradation by cations. Plant Physiol. Biochem. 42, 485-492. 
Wyman, C. E., Dale, B. E., Elander, R. T., Holtzapple, M., Ladisch, M. R., Lee, Y. Y., 2005.Coordinated Development of Leading Biomass Pretreatment Technologies.Bioresour. Technol. 96, 1959-1966.

Yang, B, Wayman, C. E., 2006. BSA Treatment to enhance Enzymatic Hydrolysis of Cellulose in Lignin Containing Substrates. Biotech.and Bioeng. 94(4), 611-617. 


\title{
CHAPTER 3. MECHANO-ENZYMATIC PRETREATMENT OF CORN STOVER (ZEA MAYS L.).
}

\author{
To be submitted to Bioresourse Technology \\ Authors: Bibu Philip George and Benjamin Dawson-Andoh
}

\begin{abstract}
The enzymatic digestibility of a pretreated corn stover is enhanced by reducing the particle size of the feed stock particles. Particle size in a range of $1-100 \mu \mathrm{m}$ was achieved by wet attrition process. These particulates were further reduced to a size ranging from $0.1-1 \mu \mathrm{m}$ and $1-11 \mu \mathrm{m}$ after enzyme hydrolysis. Particle size was reconfirmed by Image analysis values $(16.92 \pm 3.39 \mu \mathrm{m})$ by measuring approximately 275 particulates. Wet milling increases the surface to volume ratio and exposes the cell wall biopolymers to different depolymerizing enzymes used in the current study. This study shows that the treatments that were sequentially treated with Ferulic Acid Esterase, Polyglacturonase, Xylanase followed by Accellerase ${ }^{\circledR} 1000$ had the highest amount of total sugar yield (29\%) with the minimum number of enzymes used for the reaction. The highest yield of sugars $(30 \%)$ was observed in the treatment in which all the cell wall depolymerizing enzymes were used. A significant increase inthe yield of sugars were also observed in the treatments that were pretreated with CDTA (1,2-Cyclohexylenedi nitrilotetraacetic Acid) and BSA (Bovine Serum Albumin). Presence of glucose and xylose were confirmed by HPLC (High Performance Liquid Chromatography) analysis.
\end{abstract}




\subsection{Introduction}

Agricultural residues represent important sustainable lignocellulosic feedstocks for the production of fuel and other commodity products (Lynd et al., 1991, Mosier et al., 2005). Corn stover, one such under-utilized agricultural residue, is being seriously evaluated for the production of biofuels and value-added bioproducts. The availability of corn stover which comprises of corn stems, stalks, was estimated as 80-100 million dry tones per year (Kadam and McMillan, 2003). This abundance of corn stover residues makes it as a sustainable lignocellulosic feed stock for various biorefineries.

Corn stover like all lignocellulosic biomass consists of five macromolecules, cellulose, lignin, hemicelluloses, pectin and proteins. Pectins are either bound to calcium or phosphorous in corn cell wall and functions both as physical and/or chemical barrier to foreign pathogens. Pathogens attack cell wall by the production of extracellular depolymerizing cell wall depolymerizing enzymes. When cellulase enzymes are later produced, this would increase the accessibility for the cellulase enzymes to the cellulose in the cell wall for further digestion. In this study we are using the same principle to increase the accessibility of the cellulase enzyme to the cellulose using various depolmerizing enzymes.

Cellulose and hemicellulose (galactoglucomannan, glucomannan, arabinoglucuronoxylan etc.) forms a complex network of biopolymers in the lignocellulosic cell wall. Apart from these 
polysaccharides lignin, pectin (rhamnogalacturonans, galactans and arabinans), glycosylated proteins, micromolecules (extractives, smaller molecules extractable by water. Cellulose is a linear polymer of $\beta$-(14)-D-glucopyranose unitswhile hemicelluose represents a group of heterogenous non-linear $(1 \rightarrow 4)$ - $\beta$-linked-D-amorphous polysaccharides with varying structure and quality. Pectic compounds present in the lignocellulosic materials mainly consists of rhamnogalacturonan with a backbone of $\alpha-(1,4)$-linked D-galacturonic acid units and $\alpha-(1,2)$ or $\alpha-(1,4)-$ linked L-rhamnose (Fengel and Wegener, 1989). Pectic compounds are cross-linked with calcium or phosphorous ions. Polysaccharides of starch, secondary metabolites, some water-soluble organic compounds, inorganic compounds and proteins are the non-structural components of lignocelluloses (Alén, 2000). Hydroxyl-rich proline rich proteins (HRGPs), proline-rich proteins (PRPs) and glycine-rich proteins (GRPs) are present in varying quantities in corn cell wall and constitute $10 \%$ of dry weight of total biomass.

Pretreatment is the most expensive processing steps in cellulosic biomass to fermentable sugars due to "recalcitrance" of lignocellulsic substrates. The goal of any pretreatment technique is to disrupt the nanocomposite cell wall of lignocelluloses so as to enable the biocatalyst to access and hydrolyze the cellulose. Different methods which largely depend on the complete destruction of cell wall to remove the recalcitrance of corn stover have been standardized over the year's viz. steam explosion, acid treatment, pyrolysis, ammonia fiber expansion (AFEX) etc (Mousdale, 2008, Hsu et al., 1980). During these pretreatment processes different molecules are produced as by-products in smaller fractions which can inhibit the downstream conversion of fermentable sugars to biofuels. The efficiency of conversion of biomass to fermentable sugars depends upon 
feedstock characteristics and composition, pretreatment processes, and the fermentation technologies that are utilized (Diena et al., 2006, Mosier et al., 2005).

This study is based on a three step procedure for deconstruction of cell wall viz, reducing the size mechanically by wet-milling, application of chelator CDTA (1,2-Cyclohexylenedi nitrilotetraacetic Acid) for disrupting the Calcium-Pectic complexes and finally using different polyscaccharide digesting enzymes for the selective deconstruction cellulosic and hemicellulosic components.

The overall objectives of this study were to evaluate the efficacy of individual treatments as well as the combined effect of wet attrition milling (size reduction), chelators and selective cell wall deconstruction enzymes applied sequentially on the yield of total sugars released after treatment with the commercial cellulase enzyme, Accelerase ${ }^{\mathrm{TM}} 1000$.

\subsection{Experimental design.}

In order to study the effect of chelators CDTA and BSA on the yield of sugars produced, the experiment was conducted in two sets. The experiment for each set was carried out as a 6 x 6 factorial design with three replicates. The response variable for the entire experiments was measured as the amount of sugars released. The factors used for both the sets were six deconstruction enzymes and at the end of the reaction every treatment was treated with Accelerase $^{\mathrm{TM}} 1000$. Figure 3.1 shows a schematic representation of this study. 


\subsubsection{Materials and methods}

\subsubsection{Materials}

\subsubsection{Lignocellulose biomass}

Corn stover specimens were obtained from West Virginia University Farm, Morgantown WV. The stems were on average $2.5 \mathrm{~m}$ high and $50 \mathrm{~mm}$ in diameter at breast height. The specimens were air-dried at room temperature for 10 days and milled using a standard laboratory Wiley Mill to 35 mesh size $(0.5-2 \mathrm{~mm})$. The milled corn stover specimens were oven-dried at $40^{\circ} \mathrm{C}$ for 12 hours and kept in air tight containers between $5 \%$ to $8 \%$ moisture content until used.

\subsubsection{Lignocellulose cell wall deconstruction enzymes}

Six deconstruction enzymes were used for the selective deconstruction of the corn-stover biomassviz. pectinase (multifect pectinase FE, Genencore International, Rochester, New York), proteinase (promod 523P - P523P/2500, Biocatalysts, Wales, UK), ferulic acid esterase (Depol 740L, Biocatalysts, Wales, UK), polyglacturonase (pectinase 162L-P162L, Biocatalysts, Wales, UK), xylanase (Depol 761P - D761P, Biocatalysts, Wales, UK), and endoglucanase (Celluclast

1.5L FG, Novozymes, Franklinton, NC), followed by Accelerase ${ }^{\mathrm{TM}} 1000$ (Genecore $^{\mathrm{L}}$ International Inc., Rochester, NY).

\subsubsection{Chelators and other materials}

1,2-Cyclohexylenedi-nitrilo-tetraacetic Acid was used as a chelator (HACH Company, Loveland, CO., Cat. 7007-26) and Bovine Serum albumin (98\%) as the enzyme stabilizer (Sigma Aldrich, Cat. No A7906, St. Louis, MO). 


\subsubsection{Methods}

\subsubsection{Wet Attrition milling of corn stover}

Oven-dried corn-stover was soaked in $0.5 \%$ (weight by volume) sodium hydroxide $(\mathrm{NaOH})$ for $2 \mathrm{hrs}$ and initial particle size was measured microscopically prior to wet milling. Two hundred and fifty grams of $\mathrm{NaOH}$ pre-treated Wiley-milled corn-stover specimens was wet-milled at 600 RPM for 4.5 hours in a Union Process Lab Attritor Mill (Model 01-HD/01-HDDM, Akron, OH, USA)fitted with a $1400 \mathrm{~mL}$ capacity $\left(\mathrm{Al}_{2} \mathrm{O}_{3}\right)$ aluminum tank, containing grinding media of $5 \mathrm{~mm}$ zirconium oxide beads (to avoid aluminium contamination). The tank was maintained at $30{ }^{\circ} \mathrm{C}$ by means of external water via a thermostated water bath. During milling, when the slurry becomes too viscous for processing, additional $0.5 \% \mathrm{NaoH}$ was added as required to make the material flowable. Presence of any sugars in the milled slurry was determined by 3,5Dinitrosalicylic acid (DNS) assay.

\subsubsection{Chemical analysis of untreated and pretreated corn-stover}

Total amount of soluble and insoluble lignin present in corn-stover was determined as per a modification of the standard NREL method (Sluiteret al., 2008). To two hundred mg of milled corn-stover in a $100 \mathrm{ml}$ test tube, $3 \mathrm{ml} \mathrm{H}_{2} \mathrm{SO}_{4}(72 \%$ weight/volume, w/v) at room temperature was added and vortexed frequently for 2-3 hours. For further hydrolysis, the reaction mixture was diluted with $112 \mathrm{ml}$ of deionized water and autoclaved at $121^{\circ} \mathrm{C}$ for 20 minutes to hydrolyze the carbohydrates. The resulting solution was filtered and the filtrate was used to determine the total sugars as per the Dinitrosalicylic acid (DNS) assay (miller, 1959). Absorbance of the filtrate at 240nm was measured using a UV spectrophotometer to determine the acid soluble lignin content 
(Sluiter et al., 2008). The residue, insoluble lignin was oven-dried at $103 \pm 2{ }^{0} \mathrm{C}$, allowed to cool in a desiccator and weighed. The oven-dried weights of insoluble lignin was used to determine lignin content as per Sluiter's formula (Sluiter et al., 2008):

$\% \mathrm{ASL}=\left(\frac{\text { UVabs } \times \text { Volume } \times \text { Dilution }}{\epsilon \times \text { ODWsample }}\right) \times 100$

where:

$\mathrm{UVabs}=$ average $\mathrm{UV}-\mathrm{V}$ is absorbance for the sample at $240 \mathrm{~nm}$

Dilution $=\frac{\text { Sample Volume }+ \text { Diluting solvent volume }}{\text { Volume of sample }}$

$\varepsilon=$ Absorptivity of lignin at 240nm,

The amount of inorganics (ash) present in milled corn-stover specimens was determined using standard ASTM protocol ASTM E 1534 - 93.

\subsubsection{Analysis of particles by light scattering, cold field emission gun scanning electron microscopy (SEM) and Image analysis.}

MicrotracS3000/S3500 particle size analyzer (Montgomeryville, PA, USA) was used to measure the distribution of the size of wood particles before and after milling. The milled corn-stover slurry was sonicated just before each measurement. Two hundred $\mathrm{mg}$ of slurry diluted in $20 \mathrm{ml}$ deionized water was vortexed and filtered. The filtrate was analyzed as per the DNS assay for sugar content using D-glucose as the standard. Additionally, milled corn-stover specimens were analyzed by Scanning Electron Microscope (SEM) to understand the effect of wet milling on the size and morphology of the particulates. For SEM one hundred milligram of attritor milled cornstover was diluted with $50 \mathrm{ml}$ of distilled water. A smear of this solution was prepared on a glass 
side which was air dried, sputter coated in gold and examined under a Hitachi S-4700 Cold Field Emission Gun Scanning Electron Microscope (FEGSEM) at 5kV.

For image analysis, another smear of the diluted wet-milled corn-stover solution was prepared on a glass slide and photos of different fields containing the milled particulates were taken. The photos were acquired by means of DXM 1200 Digital Eclipse camera system using attached to a Nikon Eclipse E600 microscope for a total magnification of 1000X. The acquired images were processed by ACT-1 software which was further processed to gray scale for image analysis using Image J software (v.38).

\subsubsection{Sequential enzymatic depolymerization of cell wall to remove recalcitrance}

Attritor milled corn-stover specimen was subjected to sequential treatment of selective cell wall depolymerizing enzymes as per a factorial experimental design. Each factor was evaluated at triplicate levels.

Wet milled corn-stover is made to a concentration of $7 \%(\mathrm{w} / \mathrm{v})$ in a sodium acetate buffer $(\mathrm{pH}$ 5.0) in $20 \mathrm{ml}$ reaction mixtures. They were subjected to two treatments. One set of treatment contained 1\%(w/v) BSA and 5mM CDTA and another set (control) lacked these two reactants. Each treatment group was treated sequentially with seven cell-wall depolymerizing enzymes: pectinase (multifect pectinase FE, Genencore International, Rochester, New York), proteinase (promod 523P - P523P/2500, Biocatalysts, Wales, UK), ferulic acid esterase (Depol 740L, 
Biocatalysts, Wales, UK), polyglacturonase (pectinase 162L-P162L, Biocatalysts, Wales, UK), xylanase (Depol 761P - D761P, Biocatalysts, Wales, UK), and endoglucanase (Celluclast 1.5L FG, Novozymes, Franklinton, NC). At the end of each sequential treatment, Accelerase ${ }^{\mathrm{TM}} 1000$ (Genecore International Inc., Rochester, NY) was added to liberate D-Glucose that was accessible to cellulase in wood cell wall. Accelerase ${ }^{\mathrm{TM}} 1000$ is a commercial cellulose enzyme system that hydrolyzes cellulose to monmeric D-Glucose. Reaction time for each enzyme assay was set to two hours. Details of the reaction mixture and duration of the reaction are listed in Table 3.1.

D-glucose was used as a standard to measure the total amount of sugars produced after each enzyme treatment. Percentage of corn-stoverconverted to sugars was calculated taking the total amount of substrate present in the reaction mixture as $1400 \mathrm{mg}$ ( $7 \%$ in $20 \mathrm{ml})$. While the percentage of holocellulose converted was calculated as follows.

$$
\% \text { of holocellulose converted }(\mathrm{mg})=\left(\frac{\text { Total Sugars }(\mathrm{mg})}{\text { Total Holocellulose }(\mathrm{mg})}\right) * 100
$$

Distribution of milled wood particle size after enzymatic treatment was again measured by Image analysis using Microtract-S3000/S3500 particle size analyzer and post-treatment image analysis. 


\subsubsection{Analysis of sugars by Dinitrosalyclic acid assay and High Performance Liquid Chromatography}

Total sugars released were analyzed by DNS assay to determine the amount of total sugars release using D-glucose as the standard. The types of sugars produced were determined by High Performance Liquid Chromatography (HPLC) analysis using D-glucose and D-xylose as standards. The HPLC System (Waters 2695, Waters Corp., Milford, MA) consists of Waters Sugar-Pack I column (6.5 x 300 mm, Particle size $10 \mu \mathrm{m}$ [WAT085188], Waters Corp., Milford, MA) and a Waters Refractive Index (RI) detector 2414 (Waters Corp., Milford, MA). The Sugar-Pack I column was protected with a Guard-Pak [WAT088141] (Waters Corp., Milford, MA).

The post reaction mixture for HPLC analysis was prepared by first filtering through a membrane filter (pore size of $0.45 \mu 1$, Whatman - 6870-2504, Piscataway, NY) fitted to a $25 \mathrm{~mm}$ syringe. $10 \mu 1$ aliquot is pipetted into a sample vial and placed in the HPLC's sample carousel of HPLC. A linear gradient of deionized water at a flow rate of $0.20 \mathrm{ml} / \mathrm{min}$ is used to elute sugars in the test solution.

\subsection{Results and discussion}

The chemical composition of corn-stover used in this study contained $72.31 \pm 0.32$ of holocellulose (hemicelluloses and cellulose on D-glucose basis), $16.76 \pm 0.25$ of lignin and $2.03 \pm 0.30$ of inorganics (all on \% oven-dry weight basis), similar to the earlier studies by Kim et al. (2003). 
Prior to wet milling, Wiley-milled corn-stover fibers showed average dimensions of 100micrometer on microscopic analysis at 400X. Wet-milling in sodium hydroxide solution by attritor miller produced viscous, light colored slurry which was analyzed by DNS assay for the presence of monosaccharide sugars. DNS assay analysis confirms that wet milling alone did not produce monosaccharide sugars from the holocellulose.

Dimensions of corn stover particulates was measured by Image analysis using Image $\mathbf{J}$ software Ver.38 (Wayne Rasband, National Institute of Health, USA). Approximately 275 particulates were measured and the average dimensions recorded were $16.92 \pm 3.39 \mu \mathrm{m}$. These results were compared to the results obtained from Microtrac analysis (Figure 2.5a). Size of the wet-milled corn stover particulates ranged from $1 \mu \mathrm{m}$ to $100 \mu \mathrm{m}$ and the statistical distribution of particle size on Microtrac analysis shows a normal distribution with $95 \%$ of particles between ranges of $1 \mu \mathrm{m}$ - 25 $\mu \mathrm{m}$. Scanning electron microscopic analysis under a Hitachi S-4700 Cold Field Emission Gun Scanning Electron Microscope (FEGSEM) confirmed the particulate size reported above and also demonstrated that the corn stover particulates varied in shape from circular to rectangular. Scanning electron microscopy demonstrated that attrition milling of Wiley milled corn stover particles reduced dimensions from $100 \mathrm{~mm}$ to $1 \mu \mathrm{m}$ (Figure $3.5 \mathrm{c}$ ).

When treated with Accellerase ${ }^{\circledR} 1000$, treatments lacking BSA and CDTA had a minimum conversion of holocellulose to monosaccharaides $4.5 \%$ (Table 3.2). The treatments that were first pretreated with BSA and CDTA had a minimum conversion rate of $4.73 \%$ (Table 3.3). In both 
the treatments, maximum conversion rate was obtained when sequentially treated with Ferulic Acid Esterase, Polyglacturonase, Xylanase followed by Accellerase ${ }^{\circledR} 1000(10.89 \%$ and $29.77 \%$ respectively). Two way ANOVA showed that the amount of sugars produced finally were significantly higher than the controls $(\mathrm{p}=0.029)$. Treatment 1 which was treated with Accelerase $^{\mathrm{TM}} 1000$ only produced the less than $6 \%$ of total sugars in both the cases. Highest amount of total sugars were produced when treated with all cell wall depolymerizing enzymes, $30.82 \%$ (Table $3.2 \& 3.3$, Figure $3.2 \& 3.3$ ). Treatment 13 (Table 3.3) produced the highest amount of total sugars $(29.77 \%)$ with minimum number of depolymerizing enzymes. Treatment 13 consisted of sequential treatment with Ferulic Acid Esterase, Polyglacturonase and Xylanase followed by Accellerase ${ }^{\circledR}$ 1000. A holocellulosic hydrolysis was observed when BSA and CDTA were used prior to the proteinase treatment while the proteinase alone did not enhance the hydrolysis. This may be asserted due to the enzyme stabilizing property and the chelating property of BSA and CDTA respectively. A combined action of CDTA and BSA enhanced the enzymatic hydrolysis by $19 \%$ in treatment 13 . High Performance Liquid Chromatography of selected treatment hydrolsates that had higher yield of sugars demonstrated the presence of DGlucose and Xylose as free sugars (Fig. 3.4a, b, c\& d). A two factor ANOVA analysis of total sugars produced by treatments containing CDTA and BSA and control were significant effect for CDTA and BSA $(\mathrm{p}=0.007)$.

Increased Ferulic Acid Esterase activity (FAE) was observed in the treatment 13. This may be ascribed to the activity of the FAE enzyme combined with CDTA. Ferreiraa et al. (2007) also reported similar activity of FAE in sugar beet when FAE assay was used. CDTA chelates $\mathrm{Ca}^{2+}$ present in the cell wall. This increases the access of the depolymerizing enzymes to the cell wall 
by depolymerizing pectin molecules which are held by cations such as $\mathrm{Ca}^{2+}$ (Wehr et al., 2004). This enhances the activity of FAE to act on the pentosans and $\beta$-glucans present in the cell wall to release sugars. FAE did not increase the yield of sugars by the subsequent use of polyglacturonase (pectinase 162L-P162L) or Xylanase (Depol 761P - D761P). The treatment with Xylanseenzyme followed by the treatment with Accelerase ${ }^{\mathrm{TM}} 1000$ increased the sugar yield. This might be due to the activity of FAE which opened up the cell wall components to the other enzymes that was applied sequentially to depolymerize biopolymers of the cell wall.

Image analysis (data not shown) and particle size analysis (Figure 3.5b) showed that corn stover particulates decreased significantly after the enzymatic treatment. Two types of particle sizes, 0.1 - $1 \mu \mathrm{m}$ and $1-11 \mu \mathrm{m}$ was produced by enzymatic hydrolysis (Fig 3.5a \& b, image analysis data not shown).

Based on previous reports on corn stover pretreatment (Neilson et al., 1982; Mais et al., 2002; Ryu and Lee, 1983) this result also confirms that enzymatic hydrolysis reducesthe particle size of corn stover particulates. This study proves that wet milling increased the productivity of total sugars. Wet attrition milling increased the surface to volume ratio by rapidly decreasing corn stover particle size to a range of $1 \mu \mathrm{m}-11 \mu \mathrm{m}$. Therefore, wet attrition milling is a rapid particle size reductive process. The study shows that different substrates and different depolymerizing enzymes have different conversion rates. This could be attributed to various reasons like inhibitory action of the products or due to the inhibitory effects of the by-products during the current reaction or during the previous enzyme hydrolysis. In this study a considerable amount of 
xylose was released by hydrolysis of holocellulose which was also observed in treatment 10 during the HPLC analysis for sugars after the enzymatic hydrolysis.

Studies on the chelating agent, CDTA and the enzyme stabilizing agent, BSA reports that it would increase the accessibility of the cell wall depolymerizing enzymes to the cell wall biopolymers (Green et al., 1996, Yang \& Wyman, 2006). Middle lamella in plant cell walls are composed of calcium salts of pectic compounds. The CDTA would increase the efficiency of the enzyme pectinase by chelating the $\mathrm{Ca}^{2+}$ in the pectin without degrading the galacturonan chains. It is very critical to remove the $\mathrm{Ca}^{2+}$ ions for effective hydrolysis of pectins since polyglacturonase enzymes hydrolyze pectic acid by splitting glycosidic linkages adjacent to free carbonyl groups (Voragen et al., 1995). BSA increases the sugar yield by adhering to the walls of the reaction vessels which would increase the availability of the depolymerizing enzymes for reacting with corn stover. BSA is an enzyme stabilizing agent that binds competitively and irreversibly on lignin which is a potential inhibitant for the deplymerizingenzymes used during the study (Yang \& Wyman, 2006, Kawamoto et al., 1992). Naidu et al. (2007) reported that in corn by reducing the particle size of the substrates would maximize sugar yield and would reduce the amount of residual solids. Many pretreatment techniques are widely used for reducing the costs on cell wall depolymerizing enzymes. These techniques include "Physical pretreatment", "Chemical pretreatment", "Physico-chemical pretreatment", and "Biological pretreatment". Ammonia Recycle Percolation (ARP) pretreatment study conducted by Kim and Lee (2005) on corn stover solubilized about half of xylan, but retains more than $92 \%$ of the cellulose content. A coupled dilute acid pretreatment followed by enzymatic hydrolysis produced 92.5\% of the total sugars originally available in the corn stover (Lloyd and Wyman, 2007). Other 
pretreatment methods like liquid hot water treatment $(90 \%)$, wet oxidation $(85 \%)$ and sodium hydroxide treatment (82\%) had higher digestibility rates on corn stover (Mosier et al., 2005, Varga et al., 2002, Varga et al., 2004, Gupta and Lee, 2010). These techniques require high energy input or need hazardous chemicals for the conversion of feed stocks to sugars. The current method is superior to existing methods by using non- hazardous chemicals and lesser energy input when compared. Since the current study do not aim on perfecting the sequence of the depolymerizing enzymes used or standardizing the enzyme concentration it is necessary to optimize the same for an economical and effective pretreatment of corn stover.

\section{Conclusion}

Coupled mechano-enzymatic pretreatment on corn stover increased the production of sugars to $30 \%$. This can be increased even higher by standardizing the sequence of depolymerizing enzymes as well as optimizing the required enzyme concentration for each reaction. Particle size increased the surface to volume ration which was also another reason for the increases sugar yield. The experiment proved that CDTA and BSA had a significant effect on depolymerizing the cell wall biopolymers by enhancing the accessibility of enzymes to the cell wall. Even though this study has above mentioned limitations, these can be standardized to increase the sugar yield in future research. 
Table 3.1. Details of serial enzymatic treatment of the biomass using seven cell wall depolymerizing enzymes.

\begin{tabular}{|l|l|l|l|}
\hline $\begin{array}{l}\text { Enzymes used for the } \\
\text { treatment }\end{array}$ & $\begin{array}{c}\text { Temperature } \\
{ }^{\mathbf{0}} \mathbf{C}\end{array}$ & Dosage \% & $\begin{array}{l}\text { *Dosage for 7\% biomass in 20ml } \\
\text { reaction mixture }(\boldsymbol{\mu l})\end{array}$ \\
\hline Pectinase (PEC) & 50 & 2 & 28 \\
\hline Proteinase (PRO) & 55 & 0.67 & 9.38 \\
\hline $\begin{array}{l}\text { Ferulic Acid Esterase } \\
\text { (FAE) }\end{array}$ & 50 & 20 & 280 \\
\hline Polygalacturonase (POL) & 40 & 2 & 28 \\
\hline Xylanase (XYL) & 50 & 2 & 28 \\
\hline Endoglucanase (END) & 50 & 2 & 28 \\
\hline Accellerase 1000 (ACC) & 50 & 12 & 168 \\
\hline
\end{tabular}

*Dosage as per manufacturer's recommendation 
Table 3.2. Showing details of the amount of sugars produced after each enzymatic treatment without BSA and CDTA in the reaction mixture.

\begin{tabular}{|c|c|c|c|c|c|c|c|c|c|c|c|}
\hline \multirow{3}{*}{ SINo } & \multicolumn{9}{|c|}{ Sugars produced after enzymatic treatment g/L (Mean) } & \multirow{3}{*}{$\begin{array}{c}\text { \%of } \\
\text { conversion } \\
\text { (wood) }\end{array}$} & \multirow{3}{*}{$\begin{array}{c}\text { \%of } \\
\text { conversion } \\
\text { (holocellulose) }\end{array}$} \\
\hline & \multirow{2}{*}{ PEC } & \multirow{2}{*}{ PRO } & \multirow{2}{*}{ FAE } & \multirow{2}{*}{ POL } & \multirow{2}{*}{ XYL } & \multirow{2}{*}{ END } & \multirow{2}{*}{$\mathrm{ACC}$} & \multicolumn{2}{|c|}{$\begin{array}{l}\text { Tot. Sugars } \\
(\mathrm{mg})\end{array}$} & & \\
\hline & & & & & & & & $\mu$ & $\begin{array}{c}\text { S. Dev. } \\
\pm\end{array}$ & & \\
\hline 1 & $\mathrm{X}$ & $\mathrm{X}$ & $\mathrm{X}$ & $\mathrm{X}$ & $\mathrm{X}$ & $\mathrm{X}$ & 0.044 & 44.10 & 0.01 & 3.15 & 4.50 \\
\hline 2 & 0.014 & $\mathrm{X}$ & $\mathrm{X}$ & $\mathrm{X}$ & 0.009 & $\mathrm{X}$ & 0.023 & 46.04 & 0.03 & 3.29 & 4.70 \\
\hline 3 & $\mathrm{X}$ & 0.001 & $\mathrm{X}$ & $\mathrm{X}$ & 0.007 & 0.002 & 0.036 & 45.17 & 0.00 & 3.23 & 4.61 \\
\hline 4 & 0.011 & 0.028 & $X$ & $X$ & $X$ & 0.014 & 0.001 & 53.32 & 0.04 & 3.81 & 5.44 \\
\hline 5 & $\mathrm{X}$ & $\mathrm{X}$ & 0.001 & $X$ & 0.000 & 0.000 & 0.063 & 64.21 & 0.02 & 4.59 & 6.55 \\
\hline 6 & 0.012 & $X$ & 0.017 & $X$ & $\mathrm{X}$ & 0.027 & 0.024 & 79.77 & 0.01 & 5.70 & 8.14 \\
\hline 7 & $\mathrm{X}$ & 0.002 & 0.000 & $X$ & $\mathrm{X}$ & $X$ & 0.051 & 54.13 & 0.01 & 3.87 & 5.52 \\
\hline 8 & 0.018 & 0.025 & 0.008 & $X$ & 0.022 & $\mathrm{X}$ & 0.017 & 89.69 & 0.01 & 6.41 & 9.15 \\
\hline 9 & $X$ & $X$ & $X$ & 0.000 & $\mathrm{X}$ & 0.005 & 0.049 & 54.98 & 0.01 & 3.93 & 5.61 \\
\hline 10 & 0.009 & $X$ & $X$ & 0.027 & 0.018 & 0.014 & 0.017 & 84.58 & 0.02 & 6.04 & 8.63 \\
\hline 11 & $X$ & 0.000 & $X$ & 0.000 & 0.008 & $X$ & 0.042 & 50.74 & 0.01 & 3.62 & 5.18 \\
\hline 12 & 0.000 & 0.001 & $X$ & 0.000 & $\mathrm{X}$ & $\mathrm{X}$ & 0.054 & 55.74 & 0.02 & 3.98 & 5.69 \\
\hline 13 & $\mathrm{X}$ & $X$ & 0.043 & 0.016 & 0.015 & $\mathrm{X}$ & 0.033 & 106.73 & 0.00 & 7.62 & 10.89 \\
\hline 14 & 0.028 & X & 0.002 & 0.002 & $\mathrm{X}$ & $\mathrm{X}$ & 0.066 & 97.37 & 0.01 & 6.95 & 9.94 \\
\hline 15 & $\mathrm{X}$ & \begin{tabular}{|l}
0.016 \\
\end{tabular} & 0.008 & 0.007 & $\mathrm{X}$ & 0.032 & 0.018 & 80.15 & 0.02 & 5.73 & 8.18 \\
\hline 16 & 0.009 & 0.011 & 0.036 & 0.004 & 0.041 & 0.010 & 0.007 & 119.31 & 0.04 & 8.52 & 12.17 \\
\hline
\end{tabular}


Table 3.3. Showing details of the amount of sugars produced after each enzymatic treatment with BSA and CDTA in the reaction mixture.

\begin{tabular}{|c|c|c|c|c|c|c|c|c|c|c|c|}
\hline \multirow{3}{*}{ SiNo } & \multicolumn{9}{|c|}{ Sugars produced after enzymatic treatment g/L (Mean) } & \multirow{3}{*}{$\begin{array}{c}\text { \%of } \\
\text { conversion } \\
\text { (wood) }\end{array}$} & \multirow{3}{*}{$\begin{array}{c}\text { \%of } \\
\text { conversion } \\
\text { (holocellulose) }\end{array}$} \\
\hline & \multirow{2}{*}{ PEC } & \multirow{2}{*}{ PRO } & \multirow{2}{*}{ FAE } & \multirow{2}{*}{ POL } & \multirow{2}{*}{ XYL } & \multirow{2}{*}{ END } & \multirow{2}{*}{$\mathrm{ACC}$} & \multicolumn{2}{|c|}{$\begin{array}{l}\text { Tot. Sugars } \\
\text { (mg) }\end{array}$} & & \\
\hline & & & & & & & & $\mu$ & $\begin{array}{c}\text { S. Dev. } \\
\pm\end{array}$ & & \\
\hline 1 & $\mathrm{X}$ & $\mathrm{X}$ & $\mathrm{X}$ & $\mathrm{X}$ & $\mathrm{X}$ & $\mathrm{X}$ & 0.058 & 58.27 & 0.01 & 4.16 & 5.95 \\
\hline 2 & 0.017 & $\mathrm{X}$ & $\mathrm{X}$ & $\mathrm{X}$ & 0.011 & $\mathrm{X}$ & 0.029 & 56.83 & 0.01 & 4.06 & 5.80 \\
\hline 3 & $\mathrm{X}$ & 0.034 & $\mathrm{X}$ & $X$ & 0.011 & 0.004 & 0.025 & 74.16 & 0.05 & 5.30 & 7.57 \\
\hline 4 & 0.052 & 0.032 & $X$ & $X$ & $X$ & 0.041 & 0.003 & 127.83 & 0.08 & 9.13 & 13.04 \\
\hline 5 & $\mathrm{X}$ & $\mathrm{X}$ & 0.003 & $X$ & 0.008 & 0.005 & 0.049 & 64.43 & 0.02 & 4.60 & 6.57 \\
\hline 6 & 0.029 & $X$ & 0.022 & $X$ & $X$ & 0.017 & 0.048 & 115.49 & 0.02 & 8.25 & 11.78 \\
\hline 7 & $X$ & 0.007 & 0.001 & $X$ & $X$ & $X$ & 0.051 & 59.49 & 0.01 & 4.25 & 6.07 \\
\hline 8 & 0.023 & 0.021 & 0.011 & $X$ & 0.027 & $X$ & 0.017 & 100.35 & 0.01 & 7.17 & 10.24 \\
\hline 9 & $X$ & $X$ & $X$ & 0.012 & $X$ & 0.009 & 0.026 & 46.33 & 0.01 & 3.31 & 4.73 \\
\hline 10 & 0.014 & $X$ & $X$ & 0.027 & 0.024 & 0.019 & 0.013 & 96.99 & 0.01 & 6.93 & 9.90 \\
\hline 11 & $X$ & 0.015 & $X$ & 0.037 & 0.004 & $X$ & 0.027 & 83.17 & 0.02 & 5.94 & 8.49 \\
\hline 12 & 0.010 & 0.010 & $X$ & 0.005 & $X$ & $X$ & 0.029 & 53.76 & 0.01 & 3.84 & 5.49 \\
\hline 13 & $X$ & $X$ & 0.190 & 0.020 & 0.029 & $X$ & 0.053 & 291.76 & 0.03 & 20.84 & 29.77 \\
\hline 14 & 0.035 & $X$ & 0.016 & 0.012 & $X$ & $X$ & 0.075 & 138.76 & 0.01 & 9.91 & 14.16 \\
\hline 15 & $X$ & 0.050 & 0.019 & 0.019 & $X$ & 0.018 & 0.048 & 154.19 & 0.00 & 11.01 & 15.73 \\
\hline 16 & 0.028 & 0.045 & 0.062 & 0.028 & 0.044 & 0.054 & 0.041 & 302.01 & 0.02 & 21.57 & 30.82 \\
\hline
\end{tabular}




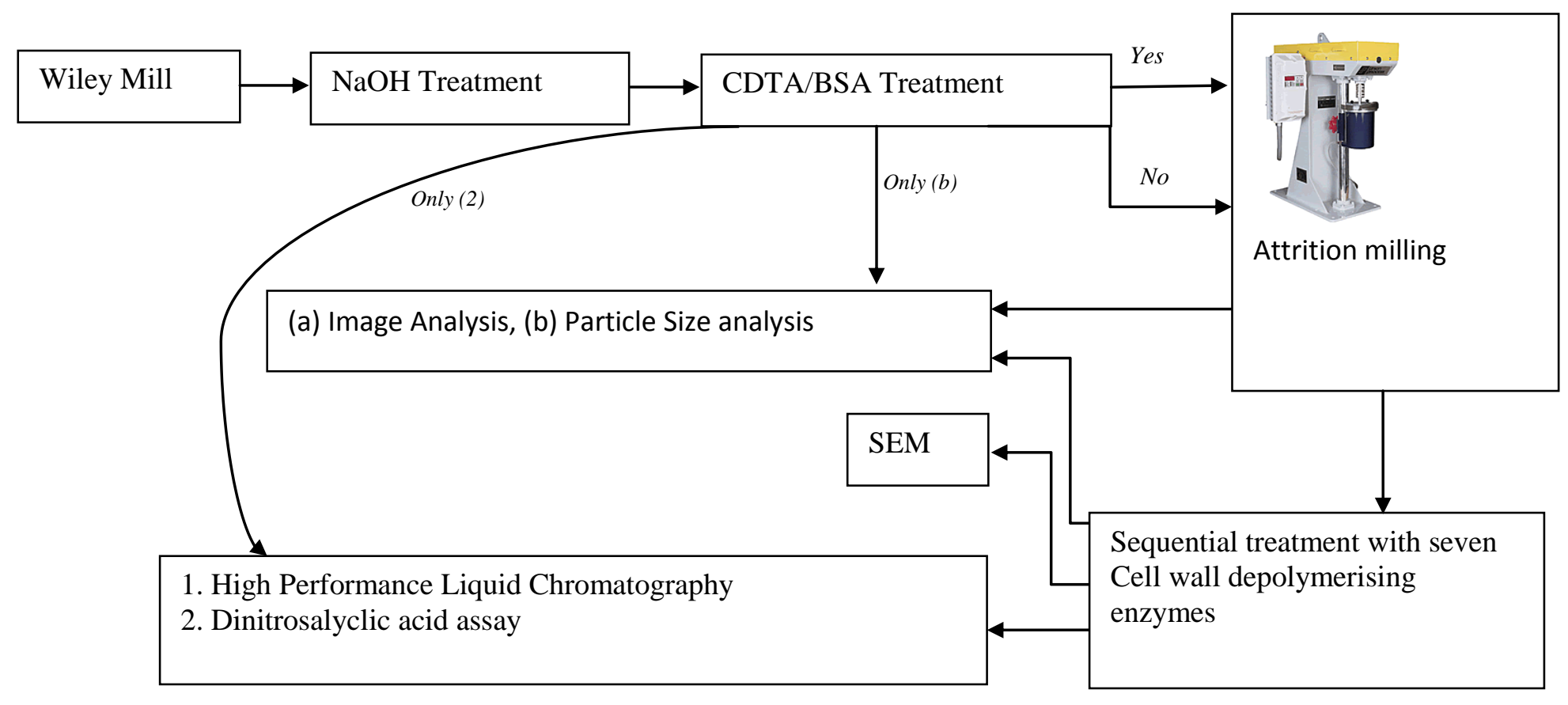

Figure 3.1. A schematic showing details of the experimental protocol used in the present study 


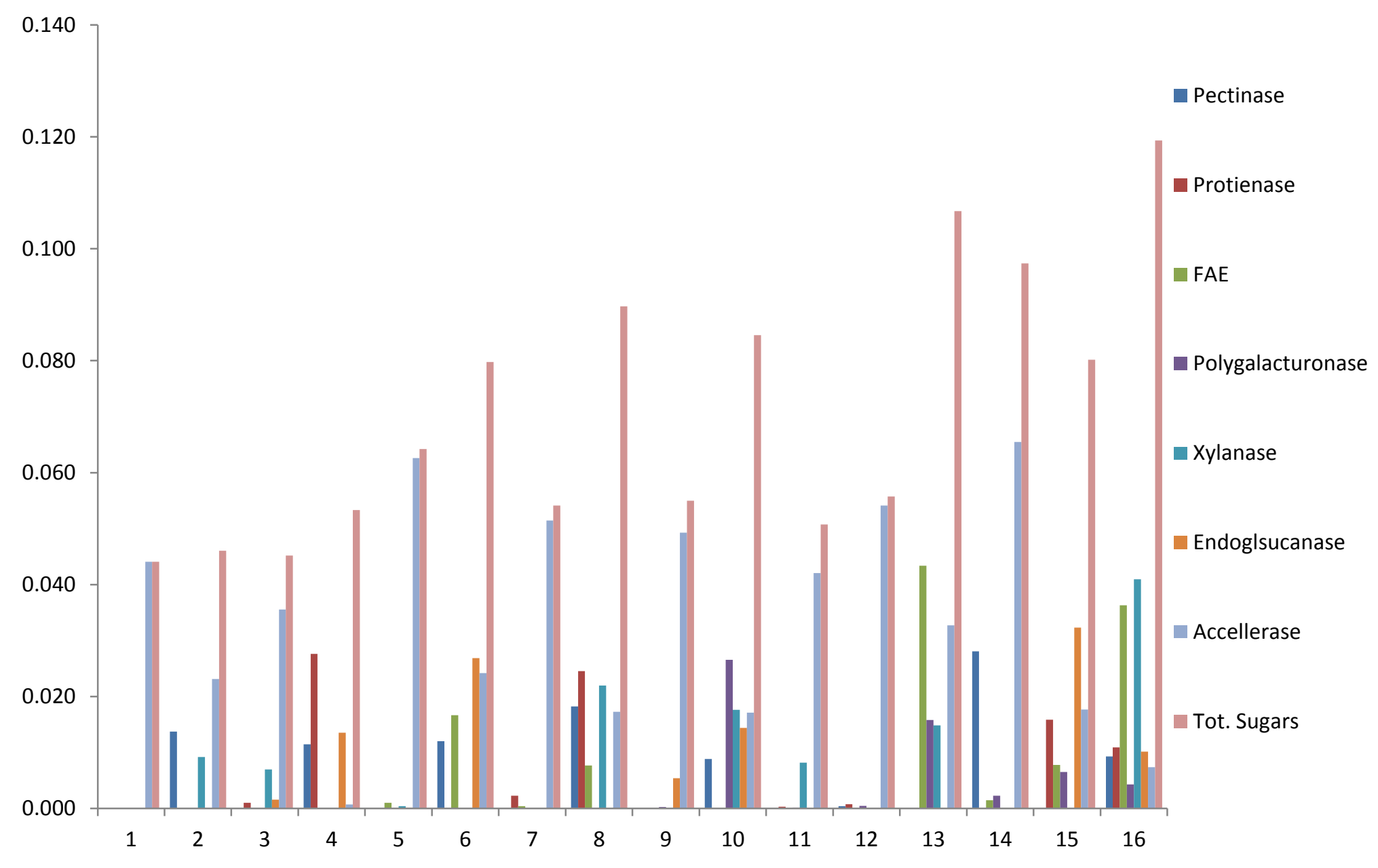

Figure 3.2.Showing details of the amount of sugars produced after each enzymatic treatment without BSA and CDTA in the reaction mixture 


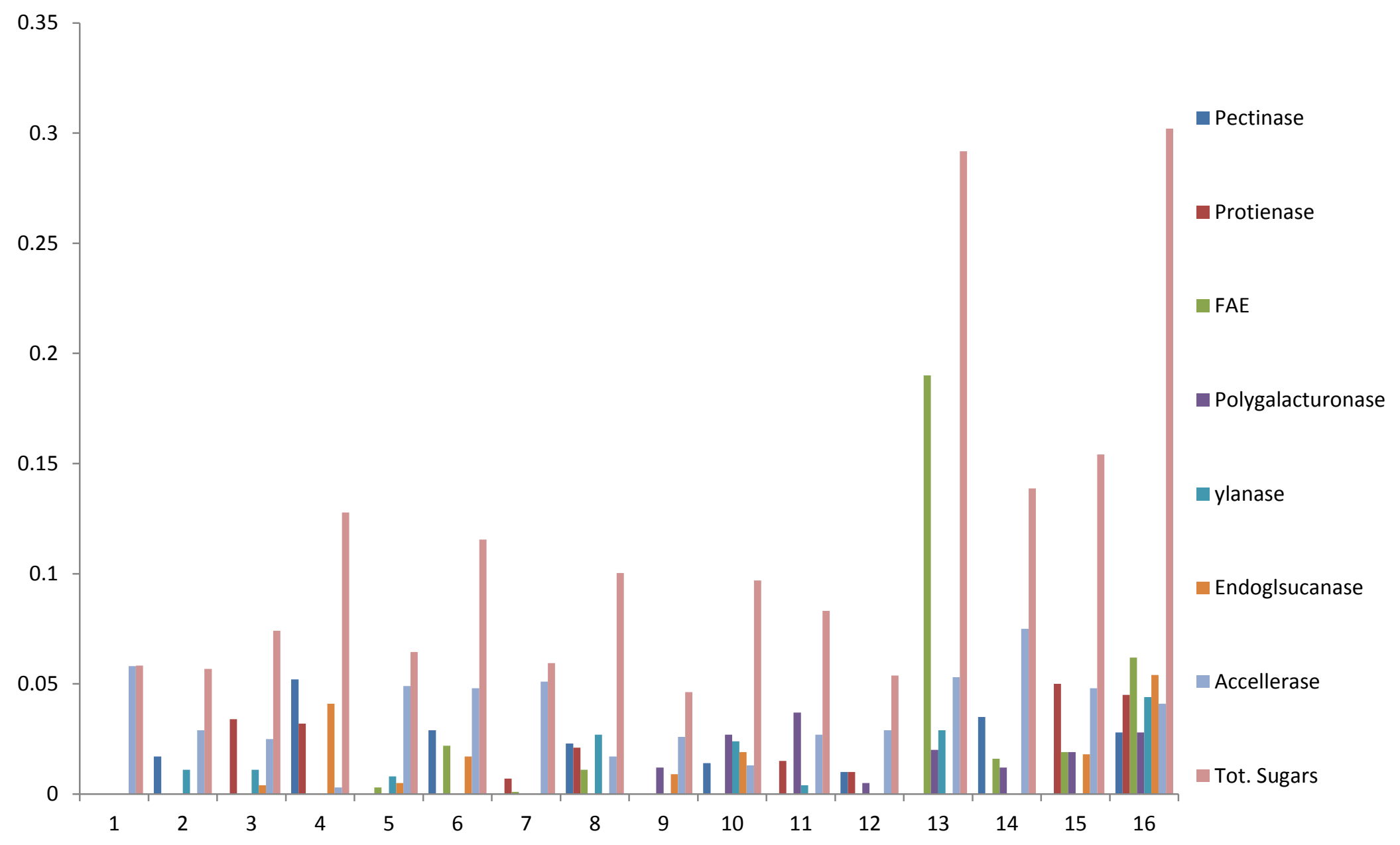

Figure 3.3. Showing details of the amount of sugars produced after each enzymatic treatment without BSA and CDTA in the reaction mixture 

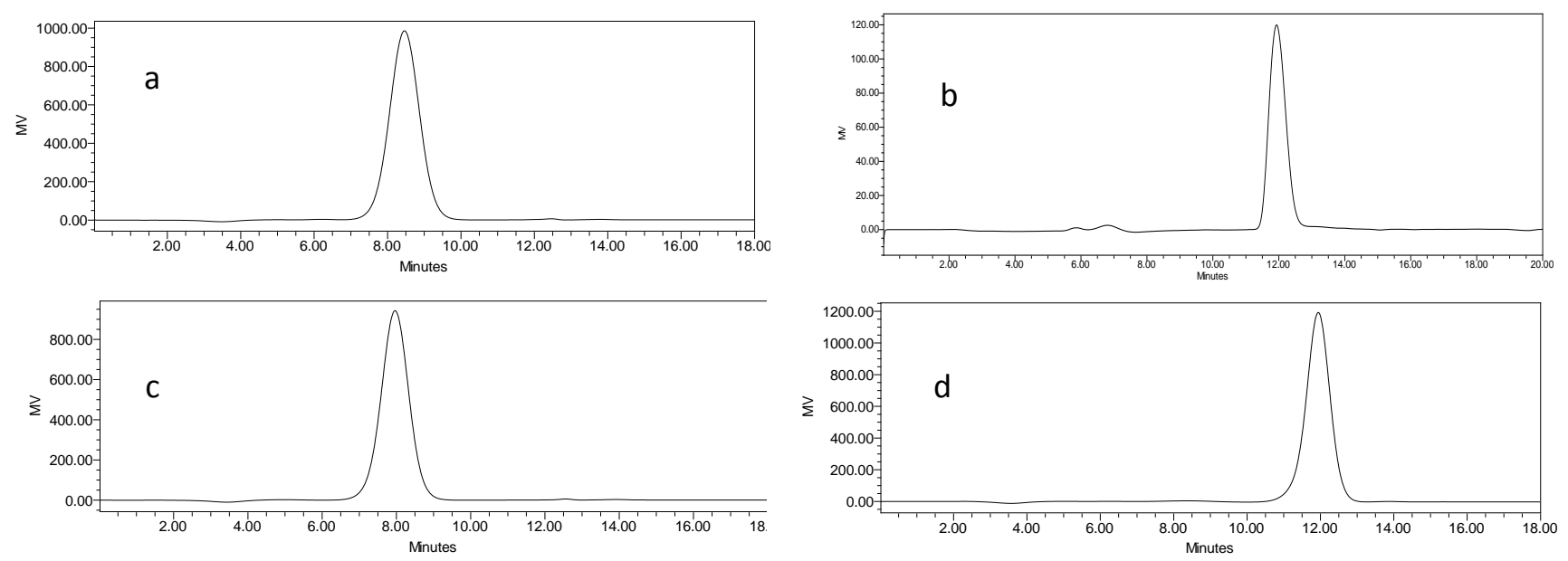

Figure 3.4. HPLC analysis for the presence of sugars after enzymatic treatment
a. Xylose standard
b. Glucose standard
c. Sample from experiment 11 with BSA \& CDTA
d. Sample from experiment 13 with BSA \& CDTA 

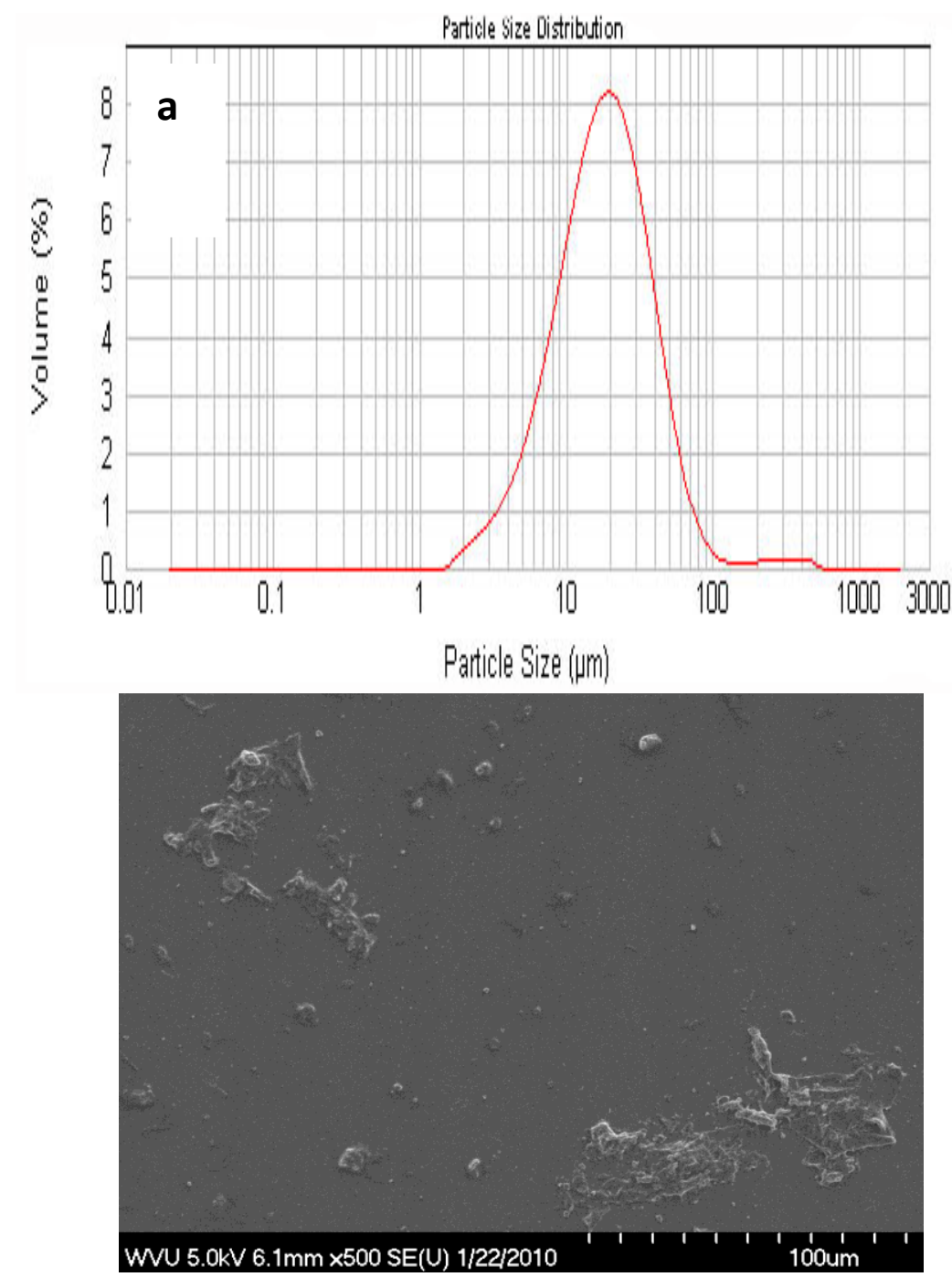

Figure 3.5.

(a) Particle size analysis after wet milling

(b), Particle size analysis after enzymatic treatment

(c) SEM of corn stover particles.

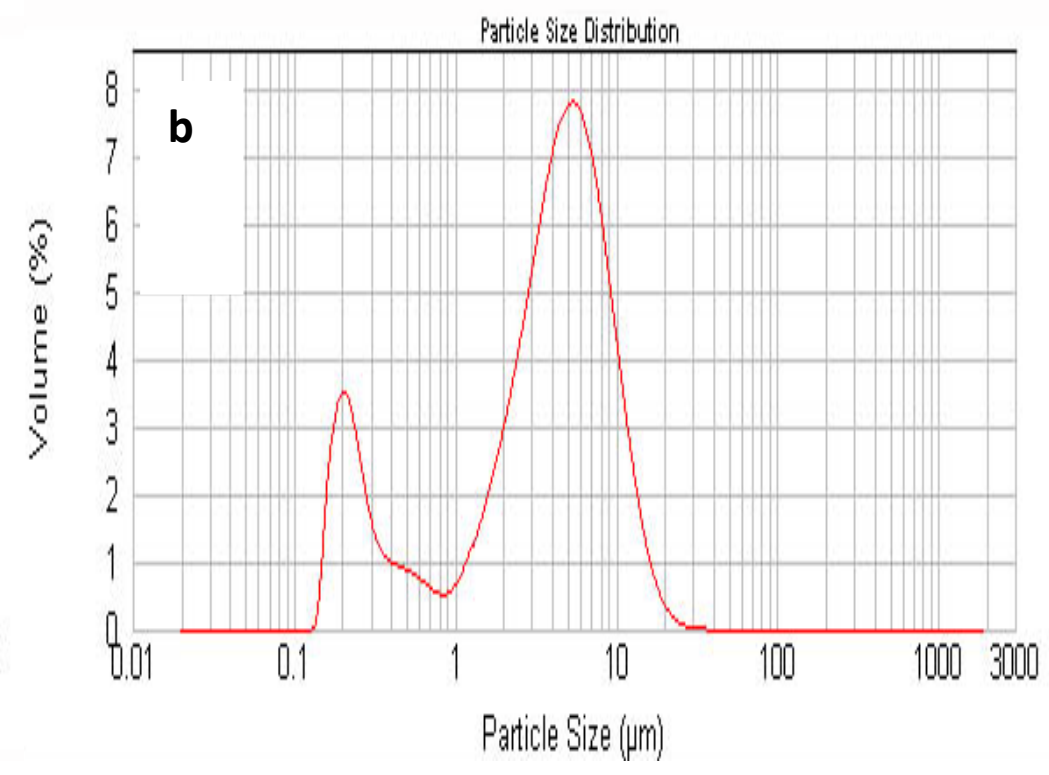




\section{References}

Alén, R., 2000. Structure and chemical composition of wood; in: Forest Products Chemistry,Eds.

J. Gullichsen, H. Paulapuro, P. Stenius, Papermaking Science and Technology 3, Fapet, Jyväskylä, Finland, 11-57.

Diena, B. S., Jungb, H. G., Vogelc, K. P., Caslerd, M. D., Lambb, J. F. S., Itena, L., Mitchellc, R. B., and Sarathc, G., 2006. Chemical composition and response to dilute-acid pretreatment and enzymatic saccharification of alfalfa, reed canarygrass, and switchgrass, Biomass and Bioenergy, $30,880-891$.

Fengel, D., Wegener, G., 1989.Wood.Chemistry, Ultrastructure, Reactions, Walter de Gruyter, Berlin, Germany, 613.

Ferreira, P., Die, N., Fauld, C.B., Soliver, J., Copa-Patiño, J.L. 2007.Release of ferulic acid and feruloylated oligosaccharides from sugar beet pulp by Streptomyces tendae, Bioresource Technol. 98, 1522-1528.

Green, F., Kuster, T. A. and Highley, T. L., 1996.Pectin Degradation during Colonization of Wood by Brow-rot Fungi.Rescent Res. Devel.In Plant Pathology, 1, 83-93.

Gupta, R and Lee, Y. Y., 2010.Pretreatment of Corn Stover and Hybrid Poplar by Sodium Hydroxide and Hydrogen Peroxide, Biotechnol.Prog., 26( 4), 1180-1186.

Hsu, T.A.,Ladisch, M.R.,Tsao, G.T., 1980. Alcohol from cellulose, Chem. Technol., 10(5), 315319. 
Kadam, K. L. and McMillan, J. D. 2003. Availability of corn stover as a sustainable feedstock for bioethanol production, Bioresour Technol., 88(1):17-25.

Kawamoto, H., Nakatsubo, F. and Murakami, K., 1992.Protein-adsorbing capacities of lignin samples.MokuzaiGakkaishi, 38(1), 81-84.

Kim, H. T., Kim, S. J., Sunwoo, C., Lee, Y. Y., 2003. Pretreatment of corn stover by aqueous ammonia, Bioresource Tech. 90, 39-47.

Kim, H. T., Lee, Y. Y., 2005. Pretreatment and fractionation of corn stover by ammonia recycle percolation process. Bioresource Tech. 96, 2007-2013.

Lloyd, T. A., Wyman, E. C., 2007. Combined sugar yields for dilute sulfuric acid pretreatment of corn stover followed by enzymatic hydrolysis of the remaining solids. Bioresource Tech. 96, 1967-1977.

Lynd, L.L., J.H. Cushman, R.J. Nichols, and C.F. Wyman. 1991. Fuel ethanol from cellulosic biomass. Science 231:1318-1323

Mais, U., Esteghlalian, A. R., Saddler, J. N., Mansfield, S. D., 2002. Enhancing the Enzymatic Hydrolysis of Cellulosic materials using simultaneous Ball Milling, Appl. Biochem. And Biotechnol., Vols. 98 - 100, 815 - 832 .

Miller, G.L., 1959. Use of Dinitrosalicylic Acid Reagent for Determination of Reducing Sugar.Anal. Chem. 31, 426-428.

Mousdale, D.M., 2008. Biofuels, Biotechnology, Chemistry and Sustainable Development. Handbook, 1st ed., CRC Press, Taylor and Francis Group. 
Mosier, N., Hendrickso, R., Ho, N., Sedlak, M., Ladisch, M.R., 2005. Optimization of pH controlled liquid hot water pretreatment of corn stover, Bioresource Technol. 96, 1986-1993.

Naidu, K., Singh, V., Johnston, D. B., Rausch, K, D., Tumbleson, M. E., 2007. Effects of ground corn particle size on ethanol yield and thin stillage soluble solids, Cereal Chem. 84, 6-9.

Neilson, M. J., Kelsey, R. G. and Shafizadeh, F., 1982.Enhancement of Enzymatic Hydrolysis by Simultaneous Attrition of Cellulosic Substrates, Biotechnol.andBioengg., 24, 293 - 304.

Ryu, S. K. and Lee, J. M., 1983.Bioconversion of Waste Cellulose by Using an Attrition Bioreactor, Biotechnol.andBioengg., 25, $53-65$.

Sluiter, A, Hames, B., Ruiz, R., Scarlata, C., Sluiter, J., Templeton, D., Crocker, D., 2008.Technical Report, National Renewable Laboratory.NREL/TP-510-42618. Available from http://www.nrel.gov/biomass/pdfs/42618.pdf

Varga E., Schmidt A.S., Réczey K., Thomsen A.B., 2002. Pretreatment of corn stover using wet oxidation to enhance enzymatic digestibility, Appl. Biochem. Biotechn. 104: 37-49.

Varga, E., Réczey, K., Zacchi, G., 2004. Optimization of steam pretreatment of corn stover to enhance enzymatic digestibility, Appl. Biochem.and Biotech., 113-116, 509-523.

Voragen, A. G. J., Pilnik, W., Thibault, J, Axelos, M. A. V., Renard, C. M. G. C., 1995. Food Sci. and Tech., 67, 287-339.

Wehr, J.B.,Menzies, N.W., Blamey, F.P.C., 2004.Inhibition of cell-wall autolysis and pectin degradation by cations. Plant Physiol.Biochem., 42: 485-492. 
Yang, B, and Wayman, C. E., 2006. BSA Treatment to enhance Enzymatic Hydrolysis of Cellulose in Lignin Containing Substrates, Biotech. andBioengg., 94(4), 611-617. 


\title{
CHAPTER 4. EFFECT OF CELL WALL DEPOLYMERIZING ENZYME CONCENTRATION ON MECHANO-ENZYMATIC PRETREATMENT OF LIGNOCELLULOSIC BIOMASS: ATR- FTIR AND SOLID-STATE ${ }^{13} \mathrm{C}$ NMR STUDIES.
}

To be published in Bioresourse Technology

\begin{abstract}
Authors: Bibu Philip George, Benjamin Dawson-Andoh and David Murray ${ }^{1}$
\end{abstract}

\begin{abstract}
The relationship of enzyme concentration and rate of hydrolysis was studied in the current investigation. For this two specimens viz. hard maple and corn stover was wet attritor milled and sequentially treated with selective depolymerizing enzymes at 1, 2, 3 and 4 times manufacturer recommended concentration. Corn stover particulates were sequentially treated with pectinase, ferulic acid esterase and endoglucanase while hard maple specimens were treated with esterase, polygalacturonase and xylanase. An increase in yield of total sugars was observed in all the treatments as the enzyme concentration was also increased. Maximum of 59\% of the theoretical yield of total sugars was observed in the corn stover treatments while $45 \%$ of total sugars were converted in the hard maple treatments. ATR-FTIR studies showed decreased intensity in the vibrational resonances at cellulose finger print region. The mid infrared studies also showed the presence of resonances at the monosaccharide fingerprint region after the enzyme hydrolysis. ${ }^{13} \mathrm{C}$ NMR CP studies also showed decreased intensity of resonances at the cellulose carbon regions. NMR studies also suggests changes in the xylan components of hemicelluloses with general decline in cellulose intensity in relation to lignin.
\end{abstract}

\footnotetext{
${ }^{1}$ National Institute for Occupational Health and Safety, 1095 Willowdale Road, M/S 3030, Morgantown, WV 26505
} 


\subsection{Introduction}

Acid hydrolysis and enzyme hydrolysis are two well established process for the liberation of sugars from lignocellulosic materials. Among the two, acid hydrolysis has a higher yield of sugars but the process requires high temperature inputs, non-corrosive reactors and strong acids while the later has a low yield of monosaccharides. At present, corn starch is the primary commercial feedstock for the production of biofuels. Lignocellulosic biomass, a non-food competitor, is therefore a more attractive feedstock for producing bio-ethanol. A potential new strategy for the development of enzyme-based pretreatment methods for lignocellulosic biomass is to use our understanding of the ultrastructure of the lignocellulsic biomass cell structure to deconstruct using either a cocktail of cell wall depolymerizing enzymes or such enzymes applied sequentially (Himmel and Picattaggio, 2008).

The lignocellulosic cell wall is a nanocomposite of macromolecules of polysaccharides (cellulose and hemicellulose - holocellulose), lignin, non-macromolecules and inorganics. Cellulose is a homogeneous polymer consisting of glucose units linked by $\beta$-1,4-glycosidic bonds. Hemicelluloses are branched, heteropolymers linked by $\beta-(1,4)$-glycosidic bonds. Nonmacro molecule includes pectin and structural proteins which are present in the plant cell wall. The most abundant pectin present in lignocellulosic biomass is rhamnogalacturonan which has a backbone of $\alpha-(1,4)$-linked D-galacturonic acid units and $\alpha-(1,2)$ or $\alpha-(1,4)$-linked L-rhamnose units (Fengel and Wegener, 1989). Structural proteins forms $10 \%$ by dry weight of the primary cell wall exist in different forms and quantities.

Although the bulk chemistries of the biomass cell wall have long been known, the architecture and molecular structure holds the key to the removal of the biomass "recalcitrance". Plant cell 
walls have developed resistance to biodeterioration and biodegradation by the reduction of access of pathogens to cell wall holocellulose. This resistance to access of carbohydrates in biomass cell wall by biocatalysts is the primary hurdle to the use of biomass as feedstock for the production of biofuels and bioproducts. This phenomenon is called "recalcitrance". To overcome this barrier - "recalcitrance", the biomass cell wall needs to be opened up and modified to permit access to the holocellulose by the biocatalysts.

Pretreatment technologies developed recently are not cost or energy efficient and also produce chemicals which inhibit subsequent biocatalyst activities such as fermentation. This directly or indirectly decreases the production of biofuels. Many of current pretreatments such as sulfuric acid pretreatment, AFEX, ionic liquids etc. has been extensively studied (Hsu et al., 1980, Singh et al., 2009). However chemicals used in some of these pretreatment methods are corrosive and environmentally incompatible. The efficiency of conversion of biomass to monomeric sugars depends upon substrate properties and composition, efficiency of the pretreatment processes, and the fermentation technologies that are utilized (Diena et al., 2006).

In this study, two elements, physical size reduction of lignocelluloses biomass (using wetattrition mill), concentration of selective cell wall "deconstruction" enzymes applied sequentially to "deconstruct" the cell wall biopolymers were studied. Enzyme stabilizer, BSA Bovine Serum Albumin (BSA) and chelator 1,2-Cyclohexylenedi nitrilo-tetraacetic Acid (CDTA) were added to bind to lignin (to prevent inactivation of enzymes) and to disrupt the pectin-calcium complexes respectively. This enhances its breakdown when treated with cell wall depolymerizing enzymes (Green et al., 1996, Yang \& Wyman, 2006). 
Attenuated total reflectance-Fourier Transform Infrared (ATR-FTIR) spectroscopy is a rapid, noninvasive technique for characterization of functional group chemistry of organic compounds. Hence, ATR-FTIR spectroscopy was used for the characterization of macromolecules in corn stover and hard maple using band assignments presented in Table 4 (Garside and Wyeth, 2003, Duarte et al., 2002). Solid-state carbon 13 nuclear magnetic resonance ( ${ }^{13} \mathrm{C}$ NMR) analyses of pretreated lignocellulosic biomass can provide valuable information on the change in chemistry after pretreatment. .

The overall objectives of this study were to spectrocopically evaluate the effect of higher concentrations of cell wall depolymerizing enzymes, corn stover or hard maple particle size, and CDTA chelator total sugar yields released after treatment with the commercial cellulase enzyme, Accelerase $^{\mathrm{TM}} 1000$.

\subsection{Experimental design.}

This study evaluated the effect of three concentration levels of selected cell wall depolymerizing enzymes on wet-attrition milled hard maple or corn stover. Each experiment was replicated. The best performing cell wall depolyermering enzymes for hard maple and corn stover reported in previous study (chapter 3) were used at concentrations two, three and four times higher than the manufacturer recommendations were used. Each treatment received final treatment of Accelerase $^{\mathrm{TM}}$ 1000. A schematic representation of the experimental design is shown in Figure 


\subsubsection{Materials and methods}

\subsubsection{Materials}

\subsubsection{Lignocellulose biomass}

Corn stover was obtained from West Virginia University Farm, Morgantown, West Virginia. The corn stover stems averaged about $2.5 \mathrm{~m}$ high and $50 \mathrm{~mm}$ in diameter. Hard maple wood were obtained from West Virginia University Research Forest, Coopers Rock, located about 12 kilometers from Morgantown, West Virginia. The trees had an average height of $10 \mathrm{~m}$ and diameter 200-300 $\mathrm{mm}$ in diameter at breast height. Both the specimens were air-dried at room temperature for 10 days and milled using a standard laboratory Wiley Mill to 35 mesh size $(0.5$ - $2 \mathrm{~mm}$ ). The milled corn stover specimens were oven-dried at $40^{\circ} \mathrm{C}$ for 12 hours and kept in air tight containers between $5 \%$ to $8 \%$ moisture content until used.

\subsubsection{Lignocellulose cell wall deconstruction enzymes}

Wet-milled hard maple wood was treated with three cell wall depolymerizing enzymes viz. pectinase (multifect pectinase FE, Genecore International, Rochester, New York), ferulic acid esterase (Depol 740L, Biocatalysts, Wales, UK) and endoglucanase (Celluclast 1.5L FG, Novozymes, Franklinton, NC). Wet-milled corn stover were treated with ferulic acid esterase (Depol 740L, Biocatalysts, Wales, UK), polyglacturonase (pectinase 162L-P162L, Biocatalysts, Wales, UK) and xylanase (Depol 761P - D761P, Biocatalysts, Wales, UK). In both specimens after treating with cell wall depolymerizing enzymes, the effect on the depolymerizing activity of these enzymes were evaluated by the treatment with Accelerase ${ }^{\mathrm{TM}} 1000$ (Genecore International Inc., Rochester, NY) for the release of monosaccharides. 


\subsubsection{Chelators and other materials}

1,2-Cyclohexylenedi-nitrilo-tetraacetic Acid (CDTA) was used as a chelator (HACH Company, Loveland, CO., Cat. 7007-26) and 98\% Bovine Serum albumin (BSA) as the enzyme stabilizer (Sigma Aldrich, Cat. No A7906, St. Louis, MO). D-Glucose (Sigma Aldrich, Cat. No G5767, St. Louis, MO) and D-Xylose (Sigma Aldrich, Cat. No X0019, St. Louis, MO) was used as standards for High Performance Liquid Chromatography (HPLC) analysis.

\subsubsection{Methods}

\subsubsection{Wet Attrition milling of lignocellulosic materials.}

Wiley-milled, oven-dried corn-stover and hard maple were each soaked in $0.5 \%$ (weight by volume, w/v) sodium hydroxide $(\mathrm{NaOH})$ for $2 \mathrm{hrs}$. Two hundred and fifty grams of $\mathrm{NaOH}$ pretreated Wiley-milled corn-stover specimens was wet-milled at 600 RPM for 4.5 hours in a Union Process Lab Attritor Mill (Model 01-HD/01-HDDM, Akron, OH, USA) fitted with a $1400 \mathrm{~mL}$ capacity $\left(\mathrm{Al}_{2} \mathrm{O}_{3}\right)$ aluminum tank. One hundred and fifty gram of $\mathrm{NaOH}$ pre-treated Wiley-milled hard maple wood specimens was wet-milled for 6 hours at 600 RPM in a Union Process Lab Attritor Mill (Model 01-HD/01-HDDM, Akron, OH, USA) fitted with a $750 \mathrm{~mL}$ capacity aluminum tank. Both specimens were milled in $\mathrm{Al}_{2} \mathrm{O}_{3}$ tank containing grinding media of $5 \mathrm{~mm}$ zirconium oxide beads (to avoid aluminum contamination). The temperature in the tank was maintained at $30^{\circ} \mathrm{C}$ by means of external water via a thermostated water bath. During milling, when the slurry becomes too viscous for processing, additional $0.5 \%(\mathrm{w} / \mathrm{v}) \mathrm{NaOH}$ was added as required to make the material flowable. Presence of any sugars in the milled slurry was determined by 3,5-Dinitrosalicylic acid (DNS) assay. 


\subsubsection{Sequential enzymatic depolymerization of lignocellulosic cell wall to remove recalcitrance}

Wet-attrition milled corn-stover and hard wood were subjected to sequential treatment of selected cell wall depolymerizing enzymes at $2 \mathrm{X}, 3 \mathrm{X}$ and $4 \mathrm{X}$ concentrations of manufacturer recommendations. Each treatment was evaluated at triplicate level.

Wet-milled corn stover or hard maple were made to a concentration of $7 \%(\mathrm{w} / \mathrm{v})$ in a sodium acetate buffer $(\mathrm{pH} 5.0)$ in $20 \mathrm{ml}$ reaction mixtures and treated with $1 \%(\mathrm{w} / \mathrm{v})$ BSA and $5 \mathrm{mM}$ CDTA. Wet-milled hard maple or corn stover specimens were sequentially treated with three cell-wall depolymerizing enzymes. Ferulic Acid Esterase (Depol 740L, Biocatalysts, Wales, UK), Polyglacturonase (pectinase 162L-P162L, Biocatalysts, Wales, UK) and Xylanase (Depol 761P - D761P, Biocatalysts, Wales, UK) was used for corn stover treatments while pectinase (multifect pectinase FE, Genencore International, Rochester, New York), ferulic acid esterase (Depol 740L, Biocatalysts, Wales, UK) and endoglucanase (Celluclast 1.5L FG, Novozymes, Franklinton, NC) were used for hard maple treatment. For both corn stove and hard maple samples, at the end of each sequential treatment, Accelerase ${ }^{\mathrm{TM}} 1000$ (Genecore International Inc., Rochester, NY) was added for the release of monosaccharaides. Reaction time for each enzyme assay was set to $2 \mathrm{hrs}$. Details of the reaction mixture and duration of the reaction are listed in Table 4.1.

After each enzyme treatment, D-glucose was used as a standard to measure the total amount of sugars released. Percentage of biomass converted to sugars was calculated taking the total 
amount of substrate present in the reaction mixture as $1400 \mathrm{mg}(7 \%$ in $20 \mathrm{ml})$. The percentage of holocellulose converted to monosaccharaides was calculated as follows.

$$
\% \text { of holocellulose converted }(\mathrm{mg})=\left(\frac{\text { Total Sugars }(\mathrm{mg})}{\text { Total Holocellulose }(\mathrm{mg})}\right) * 100
$$

\subsubsection{Analysis of sugars by 1,3 Dinitrosalyclic acid assay and High Performance Liquid Chromatography}

Total sugars released were determined by DNS assay (Miller, 1959). Types of monosaccharides produced were determined by HPLC. D-glucose and D-xylose were used as standards for the HPLC analysis. The HPLC System (Waters 2695, Waters Corp., Milford, MA) consisted of Waters Sugar-Pack I column (6.5 x 300 mm, Particle size $10 \mu \mathrm{m}$ [WAT085188], Waters Corp., Milford, MA) and a Waters Refractive Index (RI) detector 2414 (Waters Corp., Milford, MA). The Sugar-Pack I column was protected with a Guard-Pak [WAT088141] (Waters Corp., Milford, MA.

\subsubsection{Attenuated Total Reflectance (ATR) analysis of corn stover and hard maple wood}

The functional group chemistry of both controls and treated hard maple and corn stover were characterized by Attenuated Total Reflectance-Fourier Transform Infrared (ATR-FTIIR) using a Thermo Scientific Nicolet ${ }^{\mathrm{TM}}$ iS $^{\mathrm{TM}} 10$ FT-IR spectrophotometer (Thermo Scientific, USA) fitted with a Smart iTR Plate (ATR accessory for Nicolet ${ }^{\mathrm{TM}}$ iS ${ }^{\mathrm{TM}} 10$ with a single bounce Diamond crystal Plate [Thermo Scientific, USA]), with an incident angle of $42^{\circ}$ and a refractive index of 
2.4. The depth of penetration was $2.03 \mu \mathrm{m}$ at $1000 \mathrm{~cm}^{-1}$ and the sample area was $1.5 \mathrm{~mm}$. Each spectrum was averaged over 25 scans for the region $4000-500 \mathrm{~cm}^{-1}$, with a resolution of $4 \mathrm{~cm}^{-1}$, and was ratioed to the background. The spectra were evaluated with Thermo Scientific OMINIC series software suite Ver. 8.1 (Thermo Scientific, USA).

Corn stover and hard maple wood slurry was concentrated to a thick paste by air drying. This paste was coated on the Diamond Plate of Smart iTR and measured. The residue emanating from the cell wall depolymerizing enzymes were also characterized likewise.

\subsubsection{NMR Spectroscopy of corn stover and hard maple}

Control and treated hard maple were vacuum-dried prior to Solid-state ${ }^{13} \mathrm{C}$ NMR studies. Treated wood samples $(0.10-0.20 \mathrm{~g})$ were packed as dry powders into $7 \mathrm{~mm}$ zirconia rotors and analyzed in a $150 \mathrm{~mm}$ super wide bore magnet at $7.05 \mathrm{~T}$ using a Bruker Avance DMX 300 spectrometer (Bruker Biospin Corporation, Billerica, MA). Spin speed was maintained at $5.20 \pm 0.01 \mathrm{kHz}$ using dry air in a double resonance cross polarization/magic angle spinning (CP/MAS) $7 \mathrm{~mm}$ probe (also Bruker) at $298 \mathrm{~K} .{ }^{1} \mathrm{H}-{ }^{13} \mathrm{C}$ cross polarization $(\mathrm{CP})$ experiments conducted at 300.156 $\mathrm{MHz}$ and $75.4743 \mathrm{MHz}$ using a $5.4 \mu \mathrm{s}{ }^{1} \mathrm{H} 90$ degree pulse $\left(\mathrm{B}_{1 \mathrm{H}}=46 \mathrm{kHz}\right)$ followed by a $1.0 \mathrm{~ms}$ contact time. $\mathrm{B}_{1 \mathrm{C}}$ was matched to the first upper sideband. Free induction decays (FIDs) were obtained by signal-averaging 32,000 or 64,000 acquisitions over a $24 \mathrm{kHz}(318 \mathrm{ppm})$ spectral width centered at $100 \mathrm{ppm}$ using $2.5 \mathrm{~s}$ recycle delays. Spectra were generated by Fourier transformation of $4 \mathrm{k}$ data points zero-filled to $16 \mathrm{k}$ after line broadening of $20 \mathrm{~Hz}$ was applied. 
The FID acquisition time was 85 milliseconds. ${ }^{13} \mathrm{C}$ chemical shifts were referenced externally to hexamethylbenzene $\left({ }^{13} \mathrm{C} \delta_{\mathrm{CH} 3}=17.3 \mathrm{ppm}\right)$.

\subsection{Results and discussion}

Overall, total sugar yields for higher concentrations of cell wall depolymerizing enzymes were higher than controls. Total sugar yields for corn stover and hard maple were $59.46 \%$ and $45.50 \%$ respectively of theoretical value. Two way ANOVA analyses for corn stover and hard maple pretreatments showed a significant effect for enzyme concentration $(p=0.009$ and 0.03 respectively).

Attrition-milled corn stover was sequentially treated with pectinase, ferulic acid esterase, endoglucanase. Total sugar yields for double polygalacturonase enzyme concentration was approximately twice for the control. These yields were the same or little higher for $3 \mathrm{X}$ and $4 \mathrm{X}$ concentration of polygalacturonase enzyme. Minimum increase in total sugars was observed for all the FAE concentration. Slight increase in total sugar yields for $2 \mathrm{X}$ xylanase concentration whilst it doubled for $3 \mathrm{X}$ and $4 \mathrm{X}$ concentrations. Compared to the control, the amount of total sugars doubled in all the polygalacturonase treatment that had an enzyme concentration more than two times the recommended dosage (Table 4.2).

Wet-attrition milled hard maple wood was sequentially treated with ferulic acid esterase, polyglacturonase and xylanase. Pectinase and endoglucanase treatments individually did not show any significant increase in total sugar yields. Total sugar yields doubled for $2 \mathrm{X}$ concentration of FAE while it remained about the same for $3 \mathrm{X}$ and $4 \mathrm{X}$ concentrations. 
High Performance Liquid Chromatography of all hydrolsates proved the presence of D-Glucose and D-Xylose sugars (Fig. 4a, b, c \& d). One eluted peak was not identified. In both corn stover and hard maple treatments, higher yield of monosaccharides were observed $3 \mathrm{X}$ and $4 \mathrm{X}$ concentrations of cell wall depolymerizing enzymes. This is indicative of the synergistic effects of the cell wall depolymerizing enzymes. It is assumed that the deconstruction enzymes increased the accessibility of Accelerase $\mathrm{T}^{\mathrm{TM}} 1000$ to cellulose molecules in the cell wall.

Band assignments for ATR-FTIR studies are shown in Table 4.4 (Garside and Wyeth, 2003). Strong hydrogen bonded $-\mathrm{OH}$ stretching at around $4000-2750 \mathrm{~cm}^{-1}$ was observed for all spectra. Attenuated Total Reflectance-FTIR spectra (Figure 4.5a) of corn stover showed intense absorbance at $1105 \mathrm{~cm}^{-1}$ (C-O-C glycosidic ether band) and $1159 \mathrm{~cm}^{-1}$ (C-C ring breathing band). These bands arise from the polysaccharidic components of corn stover which is mainly cellulose. $\mathrm{C}=\mathrm{C}$ aromatic vibrations representing lignin were also observed at $1505 \mathrm{~cm}^{-1}$ and $1592 \mathrm{~cm}^{-1}$. The $\mathrm{C}=\mathrm{O}$ ester bands from pectin at $1735 \mathrm{~cm}^{-1}$ was absent in the ATR-FTIR analysis, an indication of the depolymerization action of pectinase on corn stover. Similar bands were observed for the ATR-FTIR spectra of hard maple wood (Fig. 5b). Intense absorbance at $1010 \mathrm{~cm}^{-1}$ and $1156 \mathrm{~cm}^{-1}$ showed the presence of cellulose. Spectral bands for lignin in the residual hard maple samples was observed at $1593 \mathrm{~cm}^{-1}$ and $1505 \mathrm{~cm}^{-1}$. Spectra of both corn stover and hard maple residual particulates showed intense and characteristic bands in the fingerprint region of sugars (1250-900 $\mathrm{cm}^{-1}$ ). The bands at $1109,1050,989$, and $904 \mathrm{~cm}^{-1}$, relate to the trace amounts of various monosaccharide sugars released during the reaction. Figure $4.5 \mathrm{a} \& \mathrm{~b}$ shows the pretreated specimens had a decrease in intensity of absorbance at cellulose fingerprint region.

The ${ }^{13} \mathrm{C}$ NMR CP spectrum of the untreated maple control (Figure 4.6a) revealed the presence of cellulose, hemicellulose and lignin carbons. Solid-state ${ }^{13} \mathrm{C}$ NMR carbon resonance assignments 
for wood components have been extensively studied. Assignments in this study are based on reviews by Maunu (2002) and by Gil and Neto (1999). Resonances at 56 and 152 ppm were assigned to lignin methoxy and phenolic carbons respectively. A broader region (129-140 ppm) corresponded to aromatic carbon-substituted carbons in lignin. The major resonances in the region 60-105 ppm were typical of cellulose and hemicellulose carbohydrate carbons, where the resonance at $105 \mathrm{ppm}$ was assigned to $\mathrm{C}_{1}$ carbons; the predominant resonances at $73-75 \mathrm{ppm}$ to $\mathrm{C}_{2}, \mathrm{C}_{3}$ and $\mathrm{C}_{5}$ carbons; the resonance at $65 \mathrm{ppm}$ to $\mathrm{C}_{6}$ carbon; and the two resonances in the region 80-91 ppm to $\mathrm{C}_{4}$ carbon in either crystalline or amorphous phases. Resonances at $22 \mathrm{ppm}$ and $175 \mathrm{ppm}$ corresponded respectively to methyl and carboxylic carbons present in these complex polymers, primarily in acetyl groups which occur in xylan structures of hemicelluloses. The processed maple spectrum (Figure 4.6b) showed generally the same carbon species, with a significant reduction of the carbohydrate carbon intensities relative to the lignin carbons. For example, the methoxy carbon intensity at $56 \mathrm{ppm}$ doubled in intensity relative to the $\mathrm{C}_{1}$ carbohydrate carbon at $105 \mathrm{ppm}$. Methyl carbon intensity at $22 \mathrm{ppm}$ declined with an increase in aliphatic carbon intensity in the range $30-50 \mathrm{ppm}$, and this accompanied downfield shifts for carboxylic carbons from $172 \mathrm{ppm}$. These shifts indicated changes in xylan components of hemicellulose with general reduction in cellulose/hemicellulose intensity relative to lignin.

From earlier studies, wet-milled corn stover and hard maple wood ranged from $1 \mu \mathrm{m}$ to $100 \mu \mathrm{m}$. In the same study, the statistical distribution of particle size on particle size analysis showed a normal distribution with $95 \%$ of particles between ranges of $1 \mu \mathrm{m}-10 \mu \mathrm{m}$ for corn stover and $10 \mu \mathrm{m}-30 \mu \mathrm{m}$ for hard maple (George et al., unpublished a, George et al., unpublished b). Dinitro salicylic assay analysis of wet-milled specimens proves the absence of sugars. Therefore, the 
mechanical action of wet-attrition milling alone did not release monosaccharides form holocellulose.

Overall, the results shows considerable hydrolysis of polysaccharides and a significant increase in the amount of sugars released during the pretreatment process. It further indicates that the increase in cell wall depolymerizing concentration increases the depolymerization of biopolymers in the cell wall. Four times cell wall depolymerizing enzyme concentration did not significantly increase total sugars produced compared to three times recommended concentration (Table 4. 2 \& 4.3). Voragen et al. (1995) reported that CDTA chelates $\mathrm{Ca}^{2+}$ ions present in the plant cell wall without degrading the galacturonan chains. CDTA chelates $\mathrm{Ca}^{2+}$ from pectin which is a plant cell wall biopolymer. Hence, it opens up other cell wall biopolymers to the depolymerizing enzymes by breaking open the bonds between pectin molecules which are held by $\mathrm{Ca}^{2+}$ molecules (Wehr et al., 2004). Earlier studies reported that the application of CDTA increase the release of pectins, on different lignocellulosic biomass (Shiga and Lajolo, 2006, Green et al., 1996, Huisman et al., 2000). Yang \& Wyman (2006) reported that BSA increase the efficiency of depolymerizing enzymes by binding to the lignin and preventing its inactivation of other enzymes. Increased ferulic acid esterase activity in corn stover might be due to the synergistic effect of CDTA and BSA on the activity of the enzymes.

Attenuated Total Reflectance-FTIR spectra showed a decrease in the absorbance of cellulose and an absorbance for sugars at their respective fingerprint regions. Similar results have been reported by Duarte et al. (2002). When compared to untreated samples, solid-state ${ }^{13} \mathrm{C}$ NMR studies confirmed the significant reduction loss of cellulose in pretreated specimens. These results are consistent with the studies on switch grass done by Reichel et al (2010). 
At present, various pretreatment protocols involving physical, chemical biological or mechanical methods or various combinations and permutations are used. Total sugar yields of some of these pretreatment methods like dilute acid hydrolysis (91\%-92\%), Ammonia Recycle Percolation (90\%-91\%), Steam explosion (90\%), Liquid hot water treatment (85\%-90\%), wet oxidation (74\%-85\%) and \%) and sodium hydroxide treatment (82\%) are high (Dale \& Moreira, 1982, Wyman et al., 2005, Kalman et al., 2002, Lloyd et al., 2005, Öhgren et al., 2005, Mosier et al., 2005, Varga et al., 2002, Varga et al., 2004, Gupta and Lee, 2010).

The approach adopted in this study is not corrosive and may require less energy. However, enzymes are still expensive. Additionally, only one sequence of application for the cell wall depolymerizing enzymes used in this study was evaluated. The results indicate synergistic effect of cell wall depolymerizing enzymes in the single sequence used on total sugar yields. Future studies should evaluate all combinations and permutations of these enzymes on total sugar yields. The order of types of cell wall depolymerizing enzymes in the sequence on total sugars yields may be important. Only one sequence was studied.

\subsection{Conclusion}

Increasing the concentration of some cell wall depolymerizing enzymes produced higher total sugars. This increase may be attributed to the synergistic effects of the cell wall depolymerizing enzymes. Wet-attrition milling reduce hard maple or corn stover particle size and increased surface area and this enhanced cell wall depolymerization and holocellulose hydrolysis. 59\% of total sugars were released in corn stover treatments while hard maple treatments had a total sugar yield of $45 \%$. This suggests that the yield of polysaccharides depends on the substrate chemistry. 
ATR-FTIR studies as well as ${ }^{13} \mathrm{C}$ NMR CP studies showed lower intensities at cellulose specific spectroscopic resonances which proves that the enzyme hydrolysis was successful on the substrates. This mechano-enzymatic pretreatment method is a useful alternative method with an application potential. 


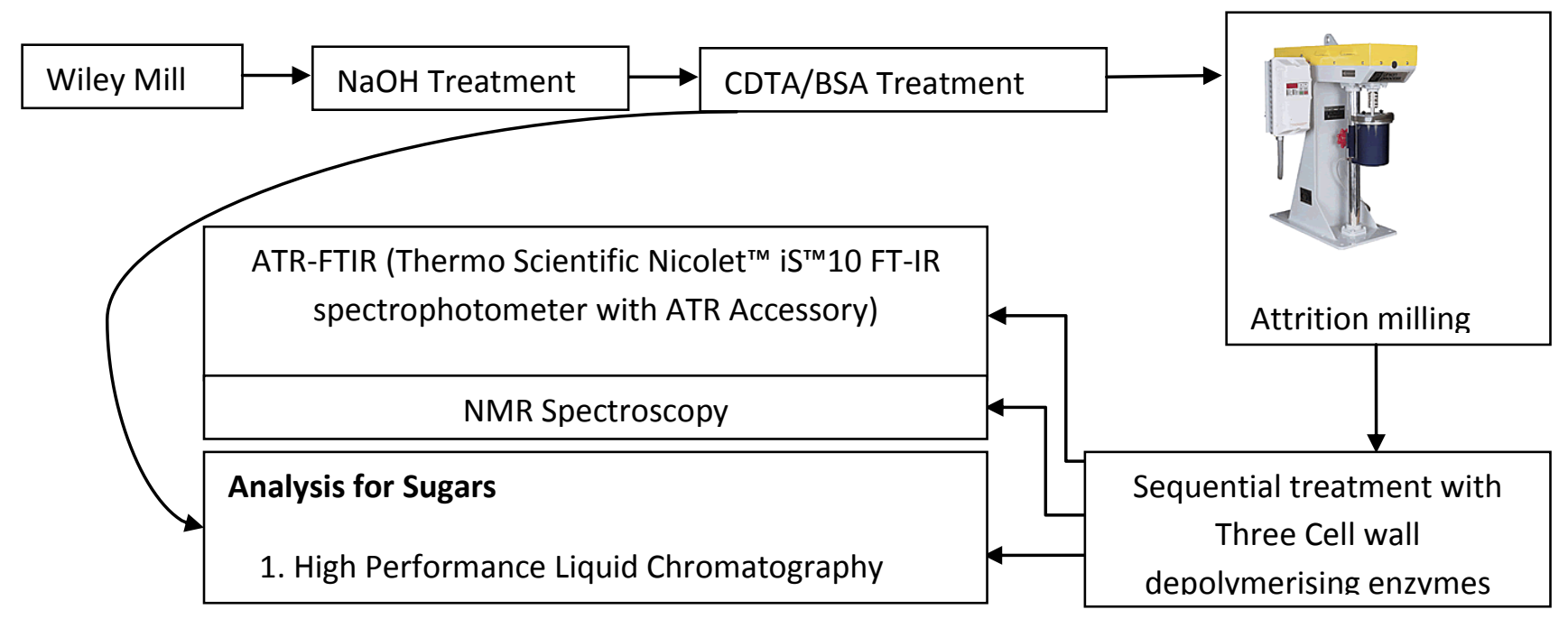

Figure 4.1. A schematic showing details of the experimental protocol used in the present study 
Table 4.1. Details of serial enzymatic treatment of the biomass using cell wall depolymerizing enzymes for corn stover

\begin{tabular}{|c|c|c|c|c|c|c|c|}
\hline \multirow[t]{2}{*}{ Specimen } & \multirow[t]{2}{*}{ Enzymes } & \multirow[t]{2}{*}{$\begin{array}{c}\text { Temperature } \\
{ }^{\circ} \mathrm{C}\end{array}$} & \multirow[t]{2}{*}{$\begin{array}{c}\text { Recommended } \\
\text { *Dosage \% }\end{array}$} & \multicolumn{4}{|c|}{$\begin{array}{c}\text { Dosage for } 7 \% \text { biomass } \\
\text { in } 20 \mathrm{ml} \text { reaction } \\
\text { mixture }(\mu \mathrm{l})\end{array}$} \\
\hline & & & & $1 \mathrm{X}$ & $2 \mathrm{X}$ & $3 \mathrm{X}$ & $4 \mathrm{X}$ \\
\hline \multirow{3}{*}{ Corn stover } & Ferulic Acid Esterase (FAE) & 50 & 20 & 280 & 560 & 840 & 1120 \\
\hline & Polygalacturonase (POL) & 40 & 2 & 28 & 56 & 84 & 112 \\
\hline & Xylanase (XYL) & 50 & 2 & 28 & 56 & 84 & 112 \\
\hline \multirow{3}{*}{ Hard maple } & Pectinase (PEC) & 50 & 2 & 28 & 56 & 84 & 112 \\
\hline & Ferulic Acid Esterase (FAE) & 50 & 20 & 280 & 560 & 840 & 1120 \\
\hline & Endoglucanase (END) & 50 & 2 & 28 & 56 & 84 & 112 \\
\hline $\begin{array}{l}\text { Corn stover } \\
\text { and } \\
\text { Hard maple }\end{array}$ & Accellerase 1000 (ACC) & 50 & 12 & 168 & 336 & 504 & 1176 \\
\hline
\end{tabular}

*Dosage as per manufacturer's recommendation 


\begin{tabular}{|c|c|c|c|c|c|c|c|c|c|c|}
\hline \multirow{3}{*}{ Specimen } & \multirow{3}{*}{ Conc. } & \multicolumn{7}{|c|}{ Sugars produced after enzymatic treatment g/L (Mean) } & \multirow{3}{*}{$\begin{array}{c}\text { \%of } \\
\text { conversion } \\
\text { of wood }\end{array}$} & \multirow{3}{*}{$\begin{array}{c}\text { \%of } \\
\text { conversion } \\
\text { (holocellulose) }\end{array}$} \\
\hline & & \multirow[b]{2}{*}{ FAE } & \multirow[b]{2}{*}{ POL } & \multirow[b]{2}{*}{ XYL } & \multirow[b]{2}{*}{$\mathrm{ACC}$} & \multirow{2}{*}{$\begin{array}{c}\text { Total } \\
\text { Sugars }\end{array}$} & \multicolumn{2}{|c|}{ Tot. Sugars } & & \\
\hline & & & & & & & $\mu$ & $\begin{array}{c}\text { S. Dev. } \\
\pm\end{array}$ & & \\
\hline \multirow{12}{*}{$\begin{array}{l}\text { Corn } \\
\text { Stover }\end{array}$} & \multirow{3}{*}{$\begin{array}{c}\text { 1X } \\
\text { Control }\end{array}$} & 0.088 & 0.096 & 0.069 & 0.066 & 319.0 & \multirow{3}{*}{313.00} & \multirow{3}{*}{6.10} & \multirow{3}{*}{22.36} & \multirow{3}{*}{31.94} \\
\hline & & 0.084 & 0.096 & 0.067 & 0.06 & 306.8 & & & & \\
\hline & & 0.082 & 0.097 & 0.069 & 0.065 & 313.2 & & & & \\
\hline & \multirow[b]{3}{*}{$2 \mathrm{X}$} & 0.083 & 0.180 & 0.082 & 0.088 & 432.3 & \multirow{3}{*}{430.80} & \multirow{3}{*}{5.70} & \multirow{3}{*}{30.77} & \multirow{3}{*}{43.96} \\
\hline & & 0.072 & 0.184 & 0.082 & 0.087 & 424.5 & & & & \\
\hline & & 0.070 & 0.190 & 0.088 & 0.088 & 435.6 & & & & \\
\hline & \multirow[b]{3}{*}{$3 X$} & 0.093 & 0.181 & 0.107 & 0.171 & 551.9 & \multirow{3}{*}{556.53} & \multirow{3}{*}{9.99} & \multirow{3}{*}{39.75} & \multirow{3}{*}{56.79} \\
\hline & & 0.083 & 0.178 & 0.118 & 0.171 & 549.7 & & & & \\
\hline & & 0.090 & 0.179 & 0.129 & 0.169 & 568.0 & & & & \\
\hline & \multirow[b]{3}{*}{$4 X$} & 0.088 & 0.190 & 0.120 & 0.179 & 577.6 & \multirow{3}{*}{582.70} & \multirow{3}{*}{6.49} & \multirow{3}{*}{41.62} & \multirow{3}{*}{59.46} \\
\hline & & 0.093 & 0.199 & 0.120 & 0.178 & 590.0 & & & & \\
\hline & & 0.091 & 0.188 & 0.122 & 0.180 & 580.5 & & & & \\
\hline
\end{tabular}

Table 4.2. Showing details of the amount of sugars produced after each enzymatic treatment in Corn Stover. 


\begin{tabular}{|c|c|c|c|c|c|c|c|c|c|c|}
\hline \multirow{3}{*}{ Specimen } & \multirow{3}{*}{ Conc. } & \multicolumn{7}{|c|}{ Sugars produced after enzymatic treatment $\mathrm{g} / \mathrm{L}$ (Mean) } & \multirow{3}{*}{$\begin{array}{c}\text { \%of } \\
\text { conversion } \\
\text { of wood }\end{array}$} & \multirow{3}{*}{$\begin{array}{c}\text { \%of } \\
\text { conversion } \\
\text { (holocellulose) }\end{array}$} \\
\hline & & \multirow[b]{2}{*}{$\mathrm{PEC}$} & \multirow[b]{2}{*}{ FAE } & \multirow[b]{2}{*}{ END } & \multirow[b]{2}{*}{$\mathrm{ACC}$} & \multirow{2}{*}{$\begin{array}{c}\text { Total } \\
\text { Sugars }\end{array}$} & \multicolumn{2}{|c|}{ Tot. Sugars } & & \\
\hline & & & & & & & $\mu$ & $\begin{array}{c}\text { S. Dev. } \\
\pm\end{array}$ & & \\
\hline \multirow{12}{*}{$\begin{array}{l}\text { Hard } \\
\text { Maple }\end{array}$} & \multirow{3}{*}{$\begin{array}{c}\text { 1X } \\
\text { Control }\end{array}$} & 0.061 & 0.066 & 0.054 & 0.05 & 231.0 & \multirow{3}{*}{229.33} & \multirow{3}{*}{3.79} & \multirow{3}{*}{16.38} & \multirow{3}{*}{23.40} \\
\hline & & 0.066 & 0.068 & 0.05 & 0.048 & 232.0 & & & & \\
\hline & & 0.059 & 0.065 & 0.049 & 0.052 & 225.0 & & & & \\
\hline & \multirow[b]{3}{*}{$2 \mathrm{X}$} & 0.052 & 0.159 & 0.062 & 0.05 & 320.5 & \multirow{3}{*}{329.60} & \multirow{3}{*}{9.36} & \multirow{3}{*}{23.54} & \multirow{3}{*}{33.63} \\
\hline & & 0.062 & 0.162 & 0.057 & 0.048 & 329.1 & & & & \\
\hline & & 0.070 & 0.155 & 0.066 & 0.049 & 339.2 & & & & \\
\hline & \multirow[b]{3}{*}{$3 X$} & 0.075 & 0.152 & 0.058 & 0.103 & 386.9 & \multirow{3}{*}{395.27} & \multirow{3}{*}{7.34} & \multirow{3}{*}{28.23} & \multirow{3}{*}{40.33} \\
\hline & & 0.075 & 0.160 & 0.059 & 0.107 & 400.6 & & & & \\
\hline & & 0.078 & 0.153 & 0.058 & 0.109 & 398.3 & & & & \\
\hline & \multirow[b]{3}{*}{$4 X$} & 0.077 & 0.151 & 0.061 & 0.152 & 440.6 & \multirow{3}{*}{445.90} & \multirow{3}{*}{6.68} & \multirow{3}{*}{31.85} & \multirow{3}{*}{45.50} \\
\hline & & 0.076 & 0.153 & 0.062 & 0.153 & 443.7 & & & & \\
\hline & & 0.072 & 0.155 & 0.063 & 0.163 & 453.4 & & & & \\
\hline
\end{tabular}

Table 4.3. Showing details of the amount of sugars produced after each enzymatic treatment in Hard Maple. 


\begin{tabular}{|l|l|}
\hline Position $\left(\mathbf{c m}^{-1}\right)$ & Assignment \\
\hline$\sim 1735$ & $v(\mathrm{C}=\mathrm{O})$ ester \\
\hline$\sim 1595$ & $v(\mathrm{C}=\mathrm{C})$ aromatic in-plane \\
\hline$\sim 1505$ & $v(\mathrm{C}=\mathrm{C})$ aromatic in-plane \\
\hline$\sim 1155$ & $v(\mathrm{C}=\mathrm{C})$ ring breathing, asymmetric \\
\hline$\sim 1050$ & $\left(\mathrm{CH}_{\mathrm{x}}-\mathrm{O}-\mathrm{H}\right.$ in alcohols $) \mathrm{C}-\mathrm{O}$ stretch \\
\hline$\sim 1109$ & $(\mathrm{C}-\mathrm{O}-\mathrm{C}$ in aliphatic ethers $) \mathrm{C}-\mathrm{O}-\mathrm{C}$ antisymmetric stretch \\
\hline$\sim 1105$ & $v(\mathrm{C}-\mathrm{O}-\mathrm{C})$ glycosidic \\
\hline$\sim 989$ & $\left(\mathrm{CH}=\mathrm{CH}_{2}\right) \mathrm{CH}_{2}$ out-of-plane deformation \\
\hline$\sim 904$ & $\left(\mathrm{CH}=\mathrm{CH}_{2}\right) \mathrm{CH}_{2}$ out-of Plane wag \\
\hline
\end{tabular}

Table 4.4. ATR-FTIR band assignments of polysaccharides and sugars 


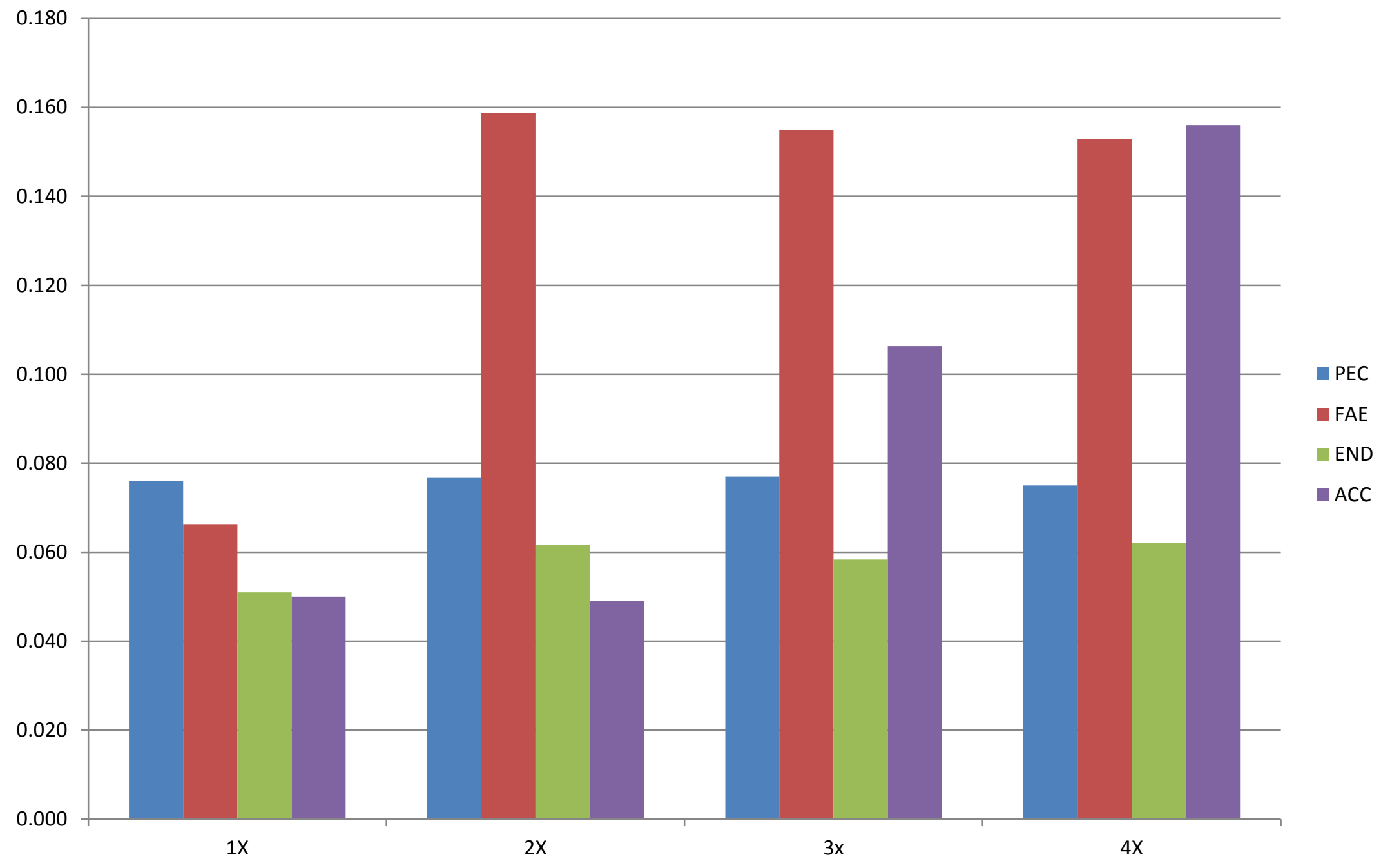

Figure 4.2. Showing details of the amount of sugars produced after each enzymatic treatment in Hard Maple. 


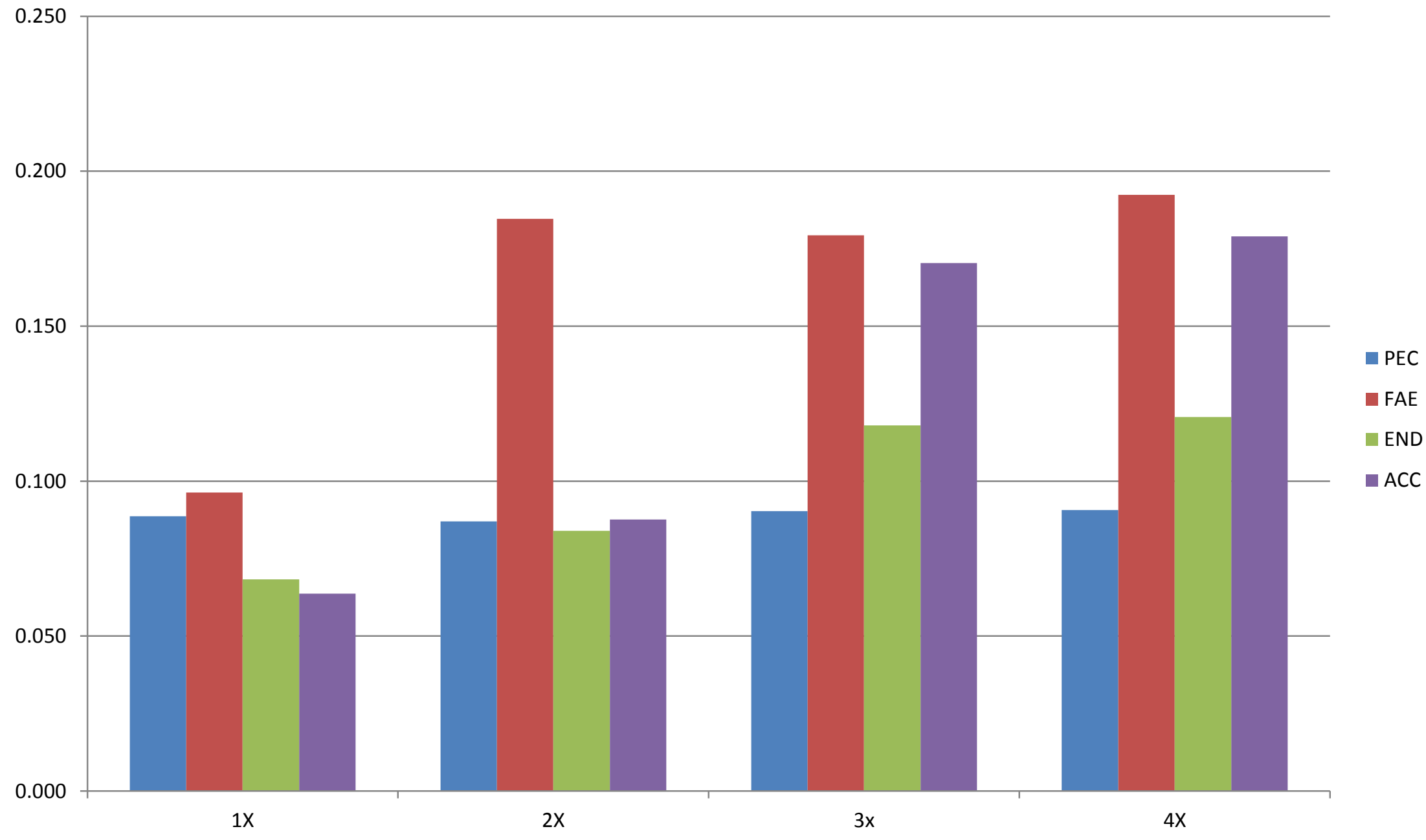

Figure 4.3 Showing details of the amount of sugars produced after each enzymatic treatment in Corn stover. 

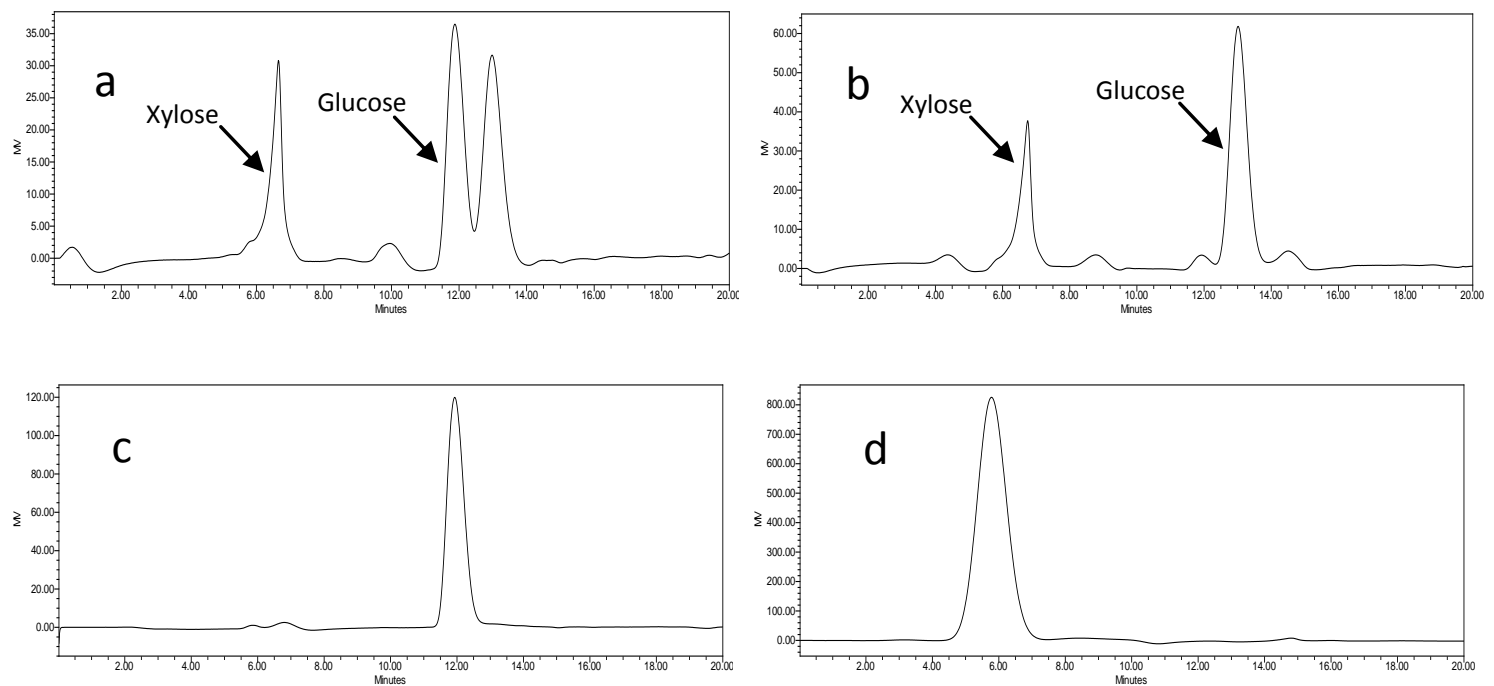

Figure 4.4 (a) Corn Stover (b) Hard Maple (c) Glucose standard (d) Xylose Standard 


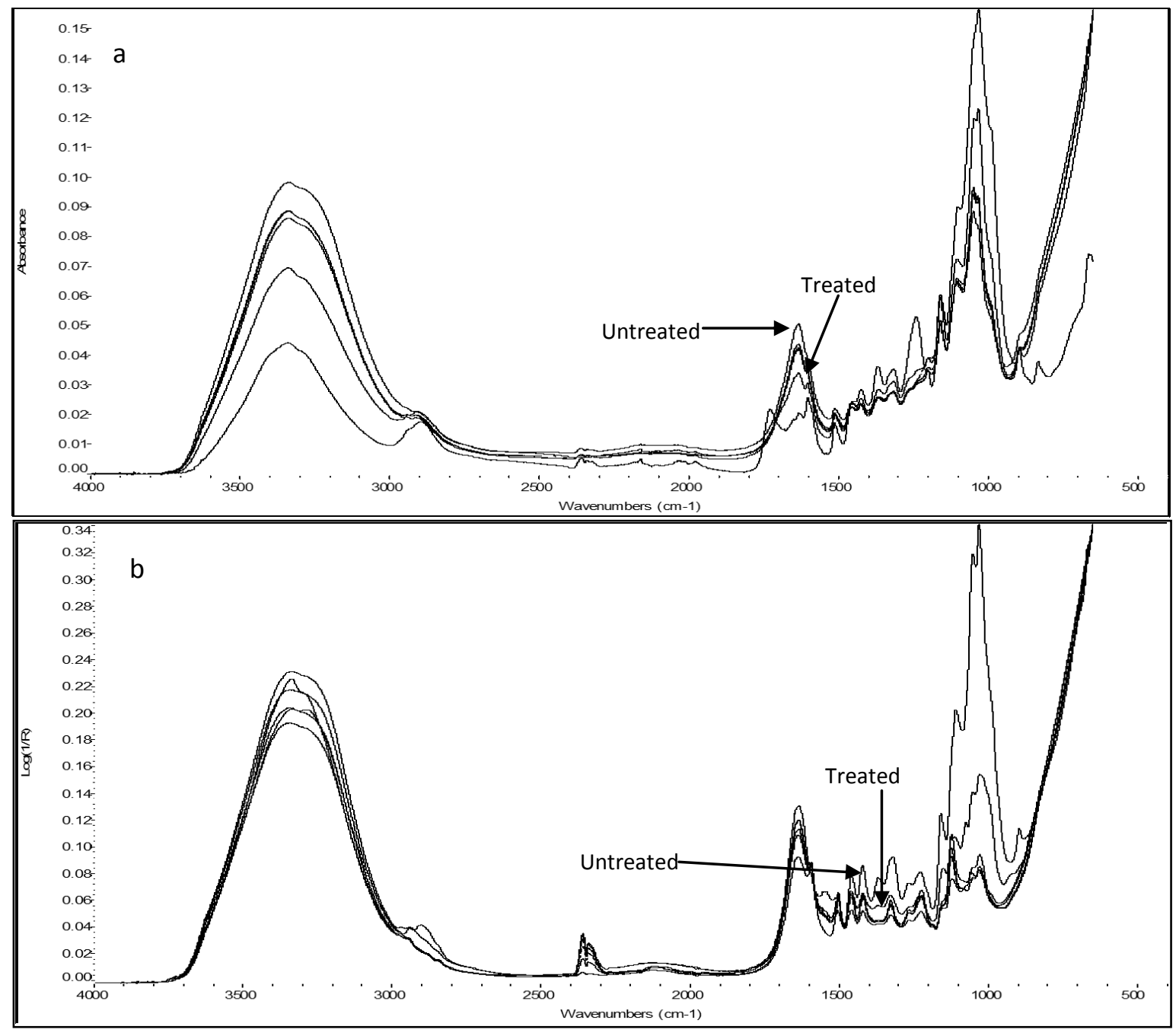

Figure 4.5. ATR-FTIR spectra of pretreated corn stover residue (a) and hard maple residue (b) between 4000 and $500 \mathrm{~cm}^{-1}$ 


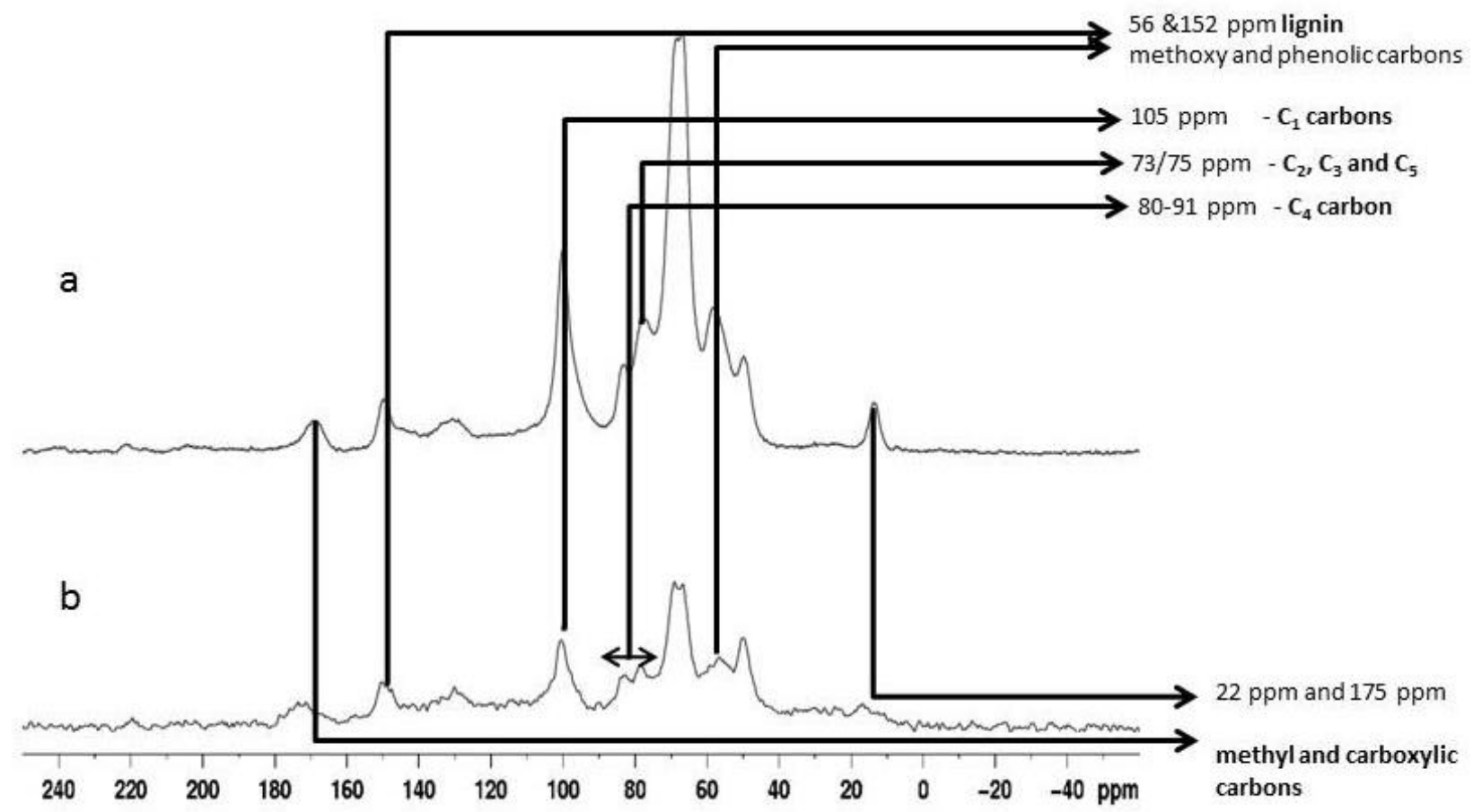

Figure 4.6. ${ }^{13} \mathrm{C}$ NMR spectra of hard maples. (a) Hard maple control, 16k scans; (b) processed hard maple, 32k scans. Spectra were obtained using ${ }^{1} \mathrm{H}-{ }^{13} \mathrm{C}$ cross polarization with $1 \mathrm{~ms}$ contact times and a 2.5 second recycle delays. "Magic angle" spin speed was $5200 \pm 10 \mathrm{~Hz}$. 


\section{References}

Dale, B. E., Moreira, M. J. 1982. Freeze-explosion technique for increasing cellulose hydrolysis.Biotechnol.Bioeng. Symp.12, 31-43.

Diena, B. S., Jungb, H. G., Vogelc, K. P., Caslerd, M. D., Lambb, J. F. S., Itena, L., Mitchellc, R. B., and Sarathc, G., 2006. Chemical composition and response to dilute-acid pretreatment and enzymatic saccharification of alfalfa, reed canarygrass, and switchgrass, Biomass and Bioenergy, $30,880-891$.

Duarte, I. F., Barros, A., Delgadillo, I., Almeida, C., Gil, A. M., 2002.Application of FTIR spectroscopy for the quantification of sugars in mango juice as a function of ripening, J. Agric. Food Chem., 50, 3104-3111.

Fengel, D., Wegener, G., 1989. Wood.Chemistry, Ultrastructure, Reactions, Walter de Gruyter, Berlin, Germany, 613.

Garside, P. and Wyeth, P., 2003. Identification of Cellulosic Fibres by FTIR Spectroscopy: Thread and Single Fiber Analysis by Attenuated Total Reflectance, International Institute for Conservation of Historic and Artistic Works, 48(4), 269-275. Available from http://www.jstor.org/stable/1506916.

George, B. P and Dawson-Andoh, B., unpublished a. Mechano-Enzymatic pretreatment of Hard maple (Acer saccharum Marsh.).

George, B. P and Dawson-Andoh, B., unpublished b. Mechano-Enzymatic pretreatment of Corn Stover (Zea mays L.). 
Gil, A. M. and Neto, C.P. ., 1999. Solid-state NMR studies of wood and other lignocellulosic materials. Annu. Rep. Spectrosc.,37, pp. 75-117.

Green, F., Kuster, T. A., Highley, T. L., 1996. Pectin Degradation during Colonization of Wood by Brow-rot Fungi.Recent Res. Devel.in Plant Pathol., 1, 83-93.

Gupta, R and Lee, Y. Y., 2010. Pretreatment of Corn Stover and Hybrid Poplar by Sodium Hydroxide and Hydrogen Peroxide, Biotechnol.Prog., 26( 4), 1180-1186.

Himmel, M. E., and Picataggio, S. K., 2008.Deeper Understanding of Biomass Recalcitrance, in: Himmel, M. E (Eds.), Biomass Recalcitrance: Deconstructing the Plant Cell Wall for Bioenergy, Blackwell Publishing Ltd, Oxford, UK pp. 1- 6.

Hsu, T.A., Ladisch, M.R., Tsao, G.T., 1980. Alcohol from cellulose, Chem. Technol., 10(5), 315-319.

Huisman, M. M. H., Fransen, C. T. M., Kamerling, J. P., Vliegenthart, J. F. G., Schols, H A. and Voragen, A. G. J., 2000. The CDTA-Soluble Pectic Substances from Soybean Meal are Composed of Rhamnogalacturonan and Xylogalacturonan but not Homogalacturonan, Biopolymers, 58(3), 279-94.

Kalman G., Varga E., and Reczey K., 2002.Diluted sulphuric acid pretreatment of corn stover at long residence times. Chem. Biochem. Eng. 16(4), 151-157.

Lloyd T. A., Wyman C. E., 2005. Combined sugar yields for dilute sulfuric acid pretreatment of corn stover followed by enzymatic hydrolysis of the remaining solids. Bioresour. Technol. 96, 1967-1977. 
Maunu, S.L, 2002. NMR studies of wood and wood products, Progress in Nuclear Magnetic Resonance Spectroscopy, 40, 151-174

Miller, G.L., 1959. Use of Dinitrosalicylic Acid Reagent for Determination of Reducing Sugar.Anal. Chem. 31, 426-428.

Mosier, N., Hendrickso, R., Ho, N., Sedlak, M., Ladisch, M.R., 2005. Optimization of pH controlled liquid hot water pretreatment of corn stover, Bioresource Technol. 96, 1986-1993.

Öhgren, K., Galbe, M., Zacchi, G., 2005. Optimization of Steam Pretreatment of SO2Impreganted Corn Stover for Fuel Ethanol Production. Appl. Biochem. and Biotech. 121, 10551068.

Reichel, S., Yunqiao, P., Marcus, F. and Ragauskas, A. J., 2010.Solid-state NMR characterization of switchgrass cellulose after dilute acid pretreatment, Biofuels, 1(1), 85-90.

Shiga, M. T. and Lajolo, F. M., 2006.Cell wall polysaccharides of common beans (Phaseolus vulgaris L.)—composition and structure, Carbohydrate Polymers, 63, 1-12.

Singh, S., Simmons, B. A., Vogel, K. P., 2009. Visualization of Biomass Solubilization and Cellulose Regeneration During Ionic Liquid Pretreatment of Switchgrass, Biotech. Bioengg., 104(1), 68-75.

Varga E., Schmidt A.S., Réczey K., Thomsen A.B., 2002. Pretreatment of corn stover using wet oxidation to enhance enzymatic digestibility, Appl. Biochem. Biotechn. 104: 37-49.

Varga, E., Réczey, K., Zacchi, G., 2004. Optimization of steam pretreatment of corn stover to enhance enzymatic digestibility, Appl. Biochem.and Biotech., 113-116, 509-523. 
Voragen, A. G. J., Pilnik, W., Thibault, J, Axelos, M. A. V., Renard, C. M. G. C., 1995. Food Sci. and Tech., 67, 287-339.

Wehr, J.B., Menzies, N.W., Blamey, F.P.C., 2004. Inhibition of cell-wall autolysis and pectin degradation by cations. Plant Physiol.Biochem., 42: 485-492.

Wyman, C. E., Dale, B. E., Elander, R. T., Holtzapple, M., Ladisch, M. R., Lee, Y. Y., 2005.Coordinated Development of Leading Biomass Pretreatment Technologies.Bioresour. Technol. 96, 1959-1966.

Yang, B, and Wayman, C. E., 2006. BSA Treatment to enhance Enzymatic Hydrolysis of Cellulose in Lignin Containing Substrates, Biotech. and Bioengg., 94(4), 611-617. 


\title{
CHAPTER 5. EFFECT OF ELECTRON BEAM IIRADIATION ON MECHANO- ENZYMATIC PRETREATMENT OF LIGNOCELLULOSIC BIOMASS: ATR-FTIR AND SOLID-STATE ${ }^{13}$ C NMR STUDIES.
}

To be published in Bioresourse Technology

Authors: Bibu Philip George, Benjamin Dawson-Andoh, David Murray ${ }^{1}$ and Adam T. Brant ${ }^{2}$

\begin{abstract}
Depolymerization of cell wall biopolymers by electron beams at three dosage levels and two energy levels, on corn stover particulates, at two different particle sizes were investigated in this study. Maximum amount of total sugars were released when wet-attrition milled corn stover (smaller particle size) were treated with the highest energy level and dosage. Lowest total sugar yields were observed for the larger particles of Wiley-milled corn stover at the lowest energy and dosage level. In general, total sugars released after enzyme hydrolysis of Wiley-milled specimens was less than for wet-attrition milled corn stover. High Performance Liquid Chromatography analysis showed that glucose and xylose were the primary monosaccharides produced. Even though, the depolymerizing action of electron beams was evident, total sugar yields were comparatively low probably due to the presence of inhibitory compounds produced by electron beam pretreatment. Attenuated total reflectance-FTIR and ${ }^{13} \mathrm{C}$ NMR Cross Polarization spectroscopic analysis showed a considerable decrease in intensity of resonances in the wet-attrition milled residues compared to the Wiley milled residues. Decrease in the intensity of resonances of pretreated specimens was also higher in the treatments that had a higher dose of irradiation.
\end{abstract}

\footnotetext{
${ }^{1}$ National Institute for Occupational Health and Safety, 1095 Willowdale Road, M/S 3030, Morgantown, WV 26505

${ }^{2}$ Graduate Student, Physics Department, West Virginia University, Morgantown WV 26506.
} 


\subsection{Introduction}

Alternative lignocellulosic substrates such as wood, agricultural residues, grass, and waste paper are potentially capable of meeting the increased demand for ethanol production and other value added products. Cellulose and hemicellulose in lignocellulosic biomass can be used as a substrate to produce a wide range of value-added products or fuels by chemical, mechanical or biological processes. For successful enzymatic conversion of lignocellulose to polysaccharides, it is necessary for the cellulase enzymes be able to access B-(1-4) glycosidic bonds present in cellulose. Other than cellulose and hemicellulose, cell wall consists of lignin, extractives and other compounds that can inhibit the activity of these hydrolyzing enzymes. This resistance of lignocellulose is commonly referred to as the recalcitrance. Therefore, it is necessary to develop an effective pretreatment method for decreasing the recalcitrance of lignocellulosic biomass.

Ionizing radiations can depolymerize lignocellulosic materials and therefore can be an efficient pretreatment technique. The radiation-induced reactions in the macromolecules of the cellulose materials occurs through rapid localization of the absorbed energy within the molecules to produce long- and short-lived radicals which initiates various chemical reactions resulting in secondary degradation of biopolymers (Khan et al., 2006). Many researchers have studied the degradation of lignocellulosic biopolymers using irradiation as a pretreatment technique on different lignocellulosic substrates viz. rice straw (Bak et al, 2009), hemp (Shin and Sung. 2008), bagasse (Kumakura and Kaetsu, 1983), wheat straw (Yang et al., 2008) and so on.

The electron beams used in the current study has two major controlled parameters impacting the depolymerization of cell wall viz. penetration power and the amount of electron dose. Penetration power of electron beams which is represented by the accelerated energy applied to 
the electrons $(\mathrm{keV})$, into the specimen results in depolymerization of cell wall polysaccharides. The electron dose is due the accelerated energy that provides the energy to electrons to penetrate to different depth in the exposed materials. As the energy level increases, penetration depth of the electrons also increases. Of the two energy levels, which were applied in the current study, $80 \mathrm{keV}$ has a penetration power up to 50 microns whereas 200 microns penetration is achieved with $150 \mathrm{keV}$. The depolymerization of cell wall biopolymers also depend on the amount of deposited energy per mass unit of material or electron dose $(\mathrm{kGy}$ or $\mathrm{kJ} / \mathrm{kg})$. This is the total energy of the electrons, absorbed by the materials per unit mass when these electrons penetrate into the exposed corn stover substrates at any given location of measurement. To reduce the required irradiation dose and accelerate the degradation of lignocellulosic materials, irradiation pretreatment of corn stover while adding low concentrations of a chelator, CDTA $((1,2-$ Cyclohexylenedi nitrilo)-tetraacetic Acid) and an enzyme stabilizer, BSA (Bovine Serum Albumin) was also studied.

Overall objective of this study was to evaluate the combined effect of irradiation and chelators on depolymerization of lignocellulosic biopolymers by measuring the release of sugars after the treatment with cellulases. The effect of the degree of irradiation on different particle sizes was also investigated.

\subsection{Experimental design.}

Two sets of experiments were carried out to study the effect of particle size on the depolymerization activity of electron beams. The factors used by both sets of experiments are varying dosage and energy levels. Details of dosage and energy level used for the present study are represented in Table 5.1. The response variable for the experiment was measured as the 
quantity of total sugars released. The factors used for the experiment were different levels of dosage and energy levels of irradiation and at the end of the reaction every treatment was treated with Accelerase $\mathrm{TM}^{\mathrm{TM}}$ 1000. Wiley-milled and attrition-milled samples used as controls were not subjected to electron beam treatments but were also treated with Accelerase ${ }^{\mathrm{TM}} 1000$ to measure the amount of total sugars released. Figure 5.1 shows a schematic representation of this study.

\subsubsection{Materials and methods}

\subsubsection{Materials}

\subsubsection{Lignocellulose biomass}

Corn stover specimens were obtained from West Virginia University Farm, Morgantown, West Virginia. The corn stover stems averaged about $2.5 \mathrm{~m}$ high and $50 \mathrm{~mm}$ in diameter. The specimens were air-dried at room temperature for 10 days and milled using a standard laboratory Wiley Mill to 35 mesh size $(0.5-2 \mathrm{~mm})$. The milled corn stover specimens were oven-dried at $40^{\circ} \mathrm{C}$ for 12 hours and kept in air tight containers between $5 \%$ to $8 \%$ moisture content until used.

\subsubsection{Evaluation of Lignocellulose cell wall depolymerization.}

The depolymerizing effect of electron beams on corn stover polysaccharides were evaluated by measuring the amount of monosaccharides released after the enzymatic treatment. Three times

$(504 \mu \mathrm{l})$ the recommended dosage of Accelerase ${ }^{\mathrm{TM}} 1000$ (Genecore International Inc., Rochester, NY) was used for the evaluation of depolymerisation of cell wall biopolymers. 


\subsubsection{Chelators and other materials}

Bovine Serum albumin (BSA 98\%) was used as the enzyme stabilizer (Sigma Aldrich, Cat. No A7906, St. Louis, MO).and 1,2-Cyclohexylenedi-nitrilo-tetraacetic Acid (CDTA) as the chelator (HACH Company, Loveland, CO., Cat. 7007-26). D-Glucose (Sigma Aldrich, Cat. No G5767, St. Louis, MO) and D-Xylose (Sigma Aldrich, Cat. No X0019, St. Louis, MO) were the standards used for High Performance Liquid Chromatography (HPLC).

\subsubsection{Methods}

\subsubsection{Wet-Attrition milling of corn stover}

Wiley-milled, oven-dried corn-stover was soaked in $0.5 \%$ (weight by volume) sodium hydroxide $(\mathrm{NaOH})$ for $2 \mathrm{hrs}$. Two hundred and fifty grams of $\mathrm{NaOH}$ pre-treated Wiley-milled corn-stover specimens was wet-milled at 600 RPM for 4.5 hours in a Union Process Lab Attritor Mill (Model 01-HD/01-HDDM, Akron, OH, USA) fitted with a $1400 \mathrm{~mL}$ capacity $\left(\mathrm{Al}_{2} \mathrm{O}_{3}\right)$ aluminum tank containing a grinding media of $5 \mathrm{~mm}$ zirconium oxide beads (to avoid aluminum contamination). The temperature in the tank was maintained at $30^{\circ} \mathrm{C}$ by means of external water via a thermostated water bath. During milling, when the slurry becomes too viscous for processing, additional $0.5 \%(\mathrm{w} / \mathrm{v}) \mathrm{NaOH}$ was added as required to make the material flowable. Presence of any sugars in the milled slurry was determined by 3,5-Dinitrosalicylic acid (DNS) assay. 


\subsubsection{Depolymerization of lignocellulosic cell wall to remove recalcitrance using electron beams.}

All electron beam irradiations were performed on an Advanced Electron Beams Applications Development Unit (ADU) equipped with an eBeam 250 electron beam emitter under ambient air. The electron energy and dose were variables used in this study while the sample speed of 50ft/min and an emitter-to-sample distance of linch were employed across all experimental setup. The electron energies included 80 and $150 \mathrm{keV}$; and the dose varied in three levels of 5, 25, 100kGy. In order to achieve uniform dose delivery of the electrons across all particles, the samples were spread out on a petri-dish with the approximate weight of $150 \mathrm{mg}$ for each irradiation exposure. Then, it was placed directly on the conveyor system tray and moved across the $75 \mathrm{~mm}$ width of the operating electron beam emitter where the EB direction was perpendicular to the petri dish surface. After the irradiation, the samples were removed from the petri-dish and the additional 150mg of samples were irradiated in a repeated manner until total of 700mg was collected for each experimental setup.

Irradiated corn stover for both sets was made to a concentration of $7 \%(w / v)$ in a sodium acetate buffer ( $\mathrm{pH}$ 5.0). This solution was divided into three replicates of $20 \mathrm{ml}$ reaction mixtures and each was treated with $1 \%(\mathrm{w} / \mathrm{v}) \mathrm{BSA}$ and $5 \mathrm{mM}$ CDTA. The reaction mixture was further treated

with $504 \mu 1$ Accelerase ${ }^{\mathrm{TM}} 1000$ enzyme for the release of monosaccharides. Reaction time for the enzyme assay was $2 \mathrm{hrs}$.

Total amount of sugars released after enzyme hydrolysis was measured by DNS assay. Dglucose was used as a standard for the assay. Percentage of biomass converted to sugars was calculated taking the total amount of substrate present in the reaction mixture as $1400 \mathrm{mg}$ ( $7 \%$ in 
20ml). The percentage of holocellulose converted to monosaccharaides was calculated using the following formula.

$$
\% \text { of holocellulose converted }(\mathrm{mg})=\left(\frac{\text { Total Sugars }(\mathrm{mg})}{\text { Total Holocellulose }(\mathrm{mg})}\right) * 100
$$

\subsubsection{Analysis of sugars by 1,3 Dinitrosalyclic acid assay and High Performance Liquid Chromatography}

Total sugars released were analyzed by DNS assay to determine the amount of total sugars release (Miller, 1959). Different types of sugars released during the enzyme hydrolysis were determined by HPLC analysis using D-glucose and D-xylose as standards. The HPLC System (Waters 2695, Waters Corp., Milford, MA) consisted of Waters Sugar-Pack I column (6.5 x 300 mm, Particle size $10 \mu \mathrm{m}$ [WAT085188], Waters Corp., Milford, MA) and a Waters Refractive Index (RI) detector 2414 (Waters Corp., Milford, MA). The Sugar-Pack I column was protected with a Guard-Pak [WAT088141] (Waters Corp., Milford, MA).

\subsubsection{Attenuated Total Reflectance (ATR) analysis of corn stover and hard maple wood}

Attenuated Total Reflectance analysis was carried out on a Thermo Scientific Nicolet ${ }^{\mathrm{TM}}$ iS $^{\mathrm{TM}} 10$ FT-IR spectrophotometer (Thermo Scientific, USA). The spectrophotometer was fitted with a Smart iTRPlate equipped with a single bounce Diamond crystal (ATR accessory for Nicolet ${ }^{\mathrm{TM}}$ iS ${ }^{\text {TM} 10 ~[T h e r m o ~ S c i e n t i f i c, ~ U S A]) . ~ D i a m o n d ~ c r y s t a l ~ o f ~ t h e ~ S m a r t ~ i T R ~ P l a t e ~ h a d ~ a n ~ i n c i d e n t ~ a n g l e ~}$ of $42^{\circ}$ and a refractive index of 2.4 . The sample area was $1.5 \mathrm{~mm}$ and the depth of penetration 
was $2.03 \mu \mathrm{m}$ at $1000 \mathrm{~cm}^{-1}$. Each spectrum had a resolution of $4 \mathrm{~cm}^{-1}$ which was ratioed to the background to produce an was average of 25 scans for the region, $4000-500 \mathrm{~cm}^{-1}$. The spectra were evaluated with Thermo Scientific OMINIC series software suite Ver. 8.1 (Thermo Scientific, USA).

Corn stover slurry was concentrated to a thick paste by air drying. This paste was coated on the sampling area of the Smart iTR plate and measured. Wiley-milled corn stover was directly measured. Untreated corn stover slurry and Wiley-milled powder were used as the control for ATR-FTIR analysis. The residue obtained after the pretreatment was measured against their respective controls to study the depolymerizing activity of the electron beams used as the pretreatment method for the current study.

\subsubsection{NMR Spectroscopy of Lignocellulosic biomass}

Irradiated, enzyme treated corn stover and residue obtained after enzyme treatment were dried under vacuum at room temperature overnight to dehydrate the moist reaction products to enable high speed sample spinning. The dehydrated materials $(0.12-0.20 \mathrm{~g})$ were packed as a dry powder into $7 \mathrm{~mm}$ zirconia rotors, as was the untreated, undried starting material. Solid-state ${ }^{13} \mathrm{C}$ NMR analysis was done in a $150 \mathrm{~mm}$ super wide bore magnet at 7.05 $\mathrm{T}$ using a Bruker Avance DMX 300 spectrometer (Bruker Biospin Corporation, Billerica, MA). Spin speed was maintained at $5.20 \pm 0.01 \mathrm{kHz}$ using dry air in a double resonance cross polarization/magic angle spinning (CP/MAS) $7 \mathrm{~mm}$ probe (also Bruker) at $298 \mathrm{~K} .{ }^{1} \mathrm{H}^{13} \mathrm{C}$ cross polarization (CP) experiments were carried out at $300.156 \mathrm{MHz}$ and $75.4743 \mathrm{MHz}$ using a $5.4 \mu \mathrm{s}{ }^{1} \mathrm{H} 90$ degree pulse $\left(B_{1 \mathrm{H}}=46 \mathrm{kHz}\right)$ followed by a $4 \mathrm{~ms}$ contact time. $\mathrm{B}_{1 \mathrm{C}}$ was matched to the first upper 
sideband. Free induction decays (FIDs) were obtained by signal-averaging 32,000 to 64,000 acquisitions over a $24 \mathrm{kHz}(180 \mathrm{ppm})$ spectral width centered at $100 \mathrm{ppm}$ using $2.5 \mathrm{~s}$ recycle delays. Spectra were generated by Fourier transformation of $4 \mathrm{k}$ data points zero-filled to $32 \mathrm{k}$ after line broadening of $20 \mathrm{~Hz}$ was applied. The FID acquisition time was 85 milliseconds. ${ }^{13} \mathrm{C}$ chemical shifts were referenced externally to hexamethylbenzene $\left({ }^{13} \mathrm{C} \delta_{\mathrm{CH} 3}=17.3 \mathrm{ppm}\right)$.

\subsection{Results and discussion}

Generally, as energy level and dosage of the electron beams increased, the amount of monosaccharides also increased. Two way analysis of variance (ANOVA) on the total sugar yield after enzyme hydrolysis showed that both the dosage and energy levels had a significance effect on depolymerisation of cell wall biopolymers. For both particle sizes, ANOVA was significant $(\mathrm{p}<0.001)$ for both the factors at 0.05 level. The control for the Wiley-milled samples and the attrition-milled samples released $3.6 \%$ and $5.95 \%$ of total sugars respectively after the treatment with Accelerase ${ }^{\mathrm{TM}} 1000$ enzyme

The effect on depolymerization of cell wall biopolymers by electron beams on different particle

sizes was evaluated by the total sugars released after treatment with Accelerase ${ }^{\mathrm{TM}} 1000$ enzyme. Maximum amount of total sugars (30.35\% of theoretical value) were released when wet-attritionmilled specimens were treated with the highest dose and energy levels (100kGy, 150keV). Lowest depolymerizing effect was found in in both the sets (10\% of sugars) when the substrates were treated at a lower dosage and energy levels $(5 \mathrm{kGy}, 80 \mathrm{keV})$.This demonstrates that electron beams depolymerizes cell wall polysaccharides and hence, enhancing the release of sugars by exposing these depolymerized polymers to cellulases. Table 5.2 shows that there was a constant 
increase in the release of total sugars when attrition-milled corn stover was pretreated with increasing dosage and energy levels. The amount of total sugars released doubled for attritionmilled samples when treated with the lowest energy and dosage levels of electron beams and increased six fold at the highest energy and dosage levels of 100kGy \& $150 \mathrm{keV}$. Even though, this trend was also found in Wiley-milled samples, the total sugar turnover was less which may be due to increased particle size of substrates. High Performance Liquid Chromatography analysis of both treatment hydrolsates showed that D-Glucose and D-Xylose were released as free sugars during the pretreatment process (Figure 5.5a, b, c).

Table 5.4 shows band assignments for the ATR-FTIR spectroscopy for this study. These assignments are based on similar studies conducted by Garside and Wyeth (2003) on the identification of cellulose fibers using FTIR spectroscopy. Strong hydrogen bonded -OH stretching at around $4000-3000 \mathrm{~cm}^{-1}$ was observed for all spectra. ATR-FTIR spectra (Figure 5.4) of both Wiley-milled and attrition-milled, irradiated corn stover showed intense absorbance at $1107 \mathrm{~cm}^{-1}$ (C-O-C glycosidic ether band) and $1160 \mathrm{~cm}^{-1}$ (C-C ring breathing band). These peaks represent the polysaccharidic components of corn stover which is mainly cellulose. $\mathrm{C}=\mathrm{C}$ aromatic vibrations representing lignin were also observed at $1507 \mathrm{~cm}^{-1}$ and $1595 \mathrm{~cm}^{-1}$. The $\mathrm{C}=\mathrm{O}$ ester bands from pectin at $1734 \mathrm{~cm}^{-1}$ was also observed. Wiley-milled, irradiated samples showed peaks at $1106,1050,988$, and $900 \mathrm{~cm}^{-1}$ in the fingerprint region of sugars $\left(1250-900 \mathrm{~cm}^{-1}\right)$ relate to the trace amounts of various monosaccharide sugars released during the reaction. These bands were weak except at $900 \mathrm{~cm}^{-1}$ which was absent in attrition-milled specimens. Figure 5.4 shows that pretreated specimens showed a decrease in intensity of absorbance at cellulose fingerprint region $\left(1107-1595 \mathrm{~cm}^{-1}\right)$ with the increase in irradiation levels. 
The ${ }^{13} \mathrm{C}$ NMR Cross Polarization (CP) spectrum of the untreated cornstalk material (Figure 5.2a) showed five polymeric carbohydrate species in the region 50-95 ppm (Maunu, 2002, Gil and Neto, 1999). Methyl groups were found upfield at around $21 \mathrm{ppm}$. Resonance intensity at 105 ppm was consistent with olefinic carbon. Carbonyls in carboxylic acids or esters were evident near $175 \mathrm{ppm}$, and the intervening peaks confirm smaller amounts of aromatic (120-140 ppm) and heteronuclear aromatic (145-160 ppm) carbon. Spinning sidebands (displaced by $69 \mathrm{ppm}$ from isotropic resonances) were not observed in this spectrum. Spectra (5.2b, c and d) represent various irradiated cornstalk material. Material degradation is evident in each material, observed as loss of intensity for carbohydrate and olefinic resonances, along with shifting for carbonyl and methyl resonances. Generally, a loss of intensity in the spectra was observed, the result of loss of protons from which the ${ }^{13} \mathrm{C}$ NMR signal is generated in $\mathrm{CP}$ experiments (Figure 5.3a, b). The losses are more severe in the aliphatic and carbonyl ester regions of the spectrum, indicating the molecular regions most affected by irradiation or enzymatic treatment processes.

Total sugar yields by irradiated, enzyme treated Wiley-milled specimens compared to wetattrition milled specimens prove that particle size has an important role in the depolymerization of polysaccharides by electron beams. The maximum depth of penetration attained by electrons beams on woody substrates are at $150 \mathrm{keV}$ is 200 microns. The Wiley-milled corn stover had $\sim 1 \mathrm{~mm}$ thickness and the irradiation treatment $150 \mathrm{keV}$ was only effective to 200 microns of the exposed corn stover substrates which might be the reason for the lower yield of sugars in Wiley milled samples. Similar results were reported by Chosdu et al (1993) after the treatment of corn stalk with an energy level of 500kGy. They observed a $23 \%$ increase in total sugar yields after the application of irradiation similar to the current results. In wet milled corn stover, increase in total sugar yield may be attributed to the increase in dosage levels which represents the amount 
of energy deposited on the exposed substrates per unit mass. As the amount of energy increased, total sugar yield increased. But a combined action of both factors did not produce higher total sugar yield by Wiley-milled substrates because of bigger particle size. Electron beams may have disrupted the heterogeneous cell wall, depolymerizing all the cell wall biopolymers as well as other compounds. The interaction of the products formed due to the depolymerizing activity of irradiation in the reaction mixture might be a possible cause of observed decreased total sugar yield. The advantage of this technique is that there was a considerable reduction in the required reaction time when compared to other electron beam pretreatment studies (Bak et al, 2009 and Chunping, 2008) that had prolonged reaction times even exceeding two days. These studies had a higher total sugar yield greater than $50 \%$ of theoretical yield of lignocellulosic substrate used.

A general loss of intensity in resonances and vibrations were observed in ${ }^{13} \mathrm{C}$ NMR and ATRFTIR spectroscopic analysis respectively. An ATR-FTIR study conducted by Duarte et al. (2002) on the quantification of sugars showed vibrations at the sugar finger printing regions, similar to the results reported here. Solid-state ${ }^{13} \mathrm{C}$ NMR studies by Sievers et al (2009) on acid hydrolyzed loblolly pine wood residues showed the trend of decreased intensity of resonance shifts at cellulose regions as observed in this study. Since lignocellulosic substrates are heterogeneous, they may produce inhibitory products after the electron beam treatment. These inhibitory compounds may be responsible for the observed decrease in total sugar yield during the enzyme hydrolysis. Future characterization studies on the intermediate compounds and end products formed during the electron beam treatment may provide a deeper insight into the chemistry of the enzymatic hydrolysis that can provide information for increasing the sugar yield. 


\subsection{Conclusion}

As a pretreatment for lignocellulosic biomass, electron beams can depolymerized biopolymers present in lignocellulosic substrates. Total sugar yields by wet-attrition milling increased when compared to the Wiley milled samples after irradiation. This might be due to the increased surface area of cellulosic substrates as well as the synergistic action of electron beams followed by enzymatic hydrolysis. Glucose and xylose were released as sugars after the treatments. After the pretreatment the spectroscopic studied proved decrease in cellulosic component of the lignocellulosic biomass which proves that the pretreatment had some effect on depolymerizing lignocellulose. A combination of irradiation with other depolymerizing enzymes or other pretreatment techniques like hot water treatment should be studied in future for better results. Further studies on the chemistry of inhibitory compounds produced during the electron beam treatment would help in designing a better pretreatment technique using electron beams. 


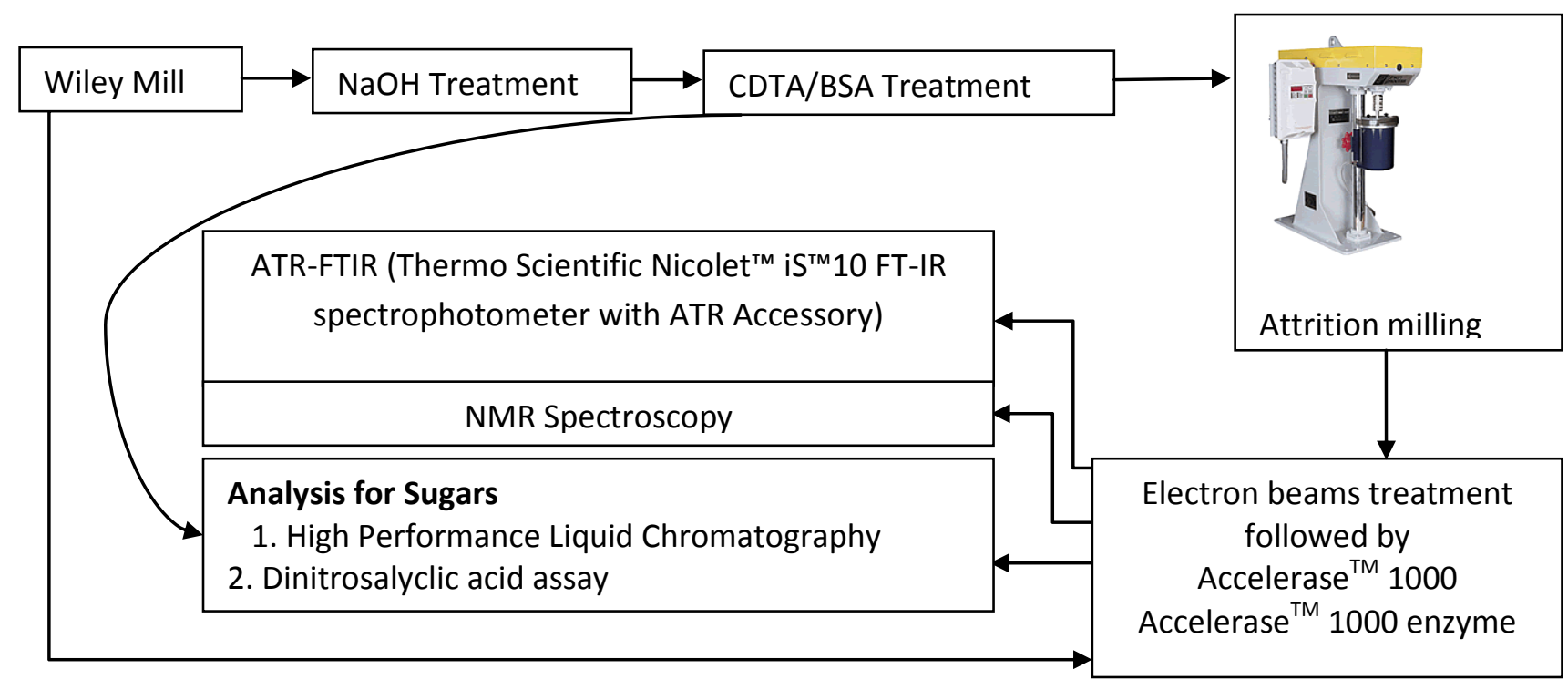

Figure 5.1. A schematic showing details of the experimental protocol used in the present study 


\begin{tabular}{|c|c|c|c|c|}
\hline Treatment \# & Dose (kGy) & Energy (keV) & $\begin{array}{c}\text { Corn stover } \\
\text { particle size }(7 \% \\
\text { w/v) } \\
\end{array}$ & $\begin{array}{c}\text { Accelerase }^{\mathrm{TM}} \\
1000(\mu \mathrm{I})\end{array}$ \\
\hline 1 & 5 & 80 & \multirow{18}{*}{ 10-30 microns } & \multirow{36}{*}{504} \\
\hline 2 & 5 & 80 & & \\
\hline 3 & 5 & 80 & & \\
\hline 4 & 25 & 80 & & \\
\hline 5 & 25 & 80 & & \\
\hline 6 & 25 & 80 & & \\
\hline 7 & 100 & 80 & & \\
\hline 8 & 100 & 80 & & \\
\hline 9 & 100 & 80 & & \\
\hline 10 & 5 & 150 & & \\
\hline 11 & 5 & 150 & & \\
\hline 12 & 5 & 150 & & \\
\hline 13 & 25 & 150 & & \\
\hline 14 & 25 & 150 & & \\
\hline 15 & 25 & 150 & & \\
\hline 16 & 100 & 150 & & \\
\hline 17 & 100 & 150 & & \\
\hline 18 & 100 & 150 & & \\
\hline 19 & 5 & 80 & \multirow{18}{*}{$100 \mathrm{~mm}$} & \\
\hline 20 & 5 & 80 & & \\
\hline 21 & 5 & 80 & & \\
\hline 22 & 25 & 80 & & \\
\hline 23 & 25 & 80 & & \\
\hline 24 & 25 & 80 & & \\
\hline 25 & 100 & 80 & & \\
\hline 26 & 100 & 80 & & \\
\hline 27 & 100 & 80 & & \\
\hline 28 & 5 & 150 & & \\
\hline 29 & 5 & 150 & & \\
\hline 30 & 5 & 150 & & \\
\hline 21 & 25 & 150 & & \\
\hline 32 & 25 & 150 & & \\
\hline 33 & 25 & 150 & & \\
\hline 34 & 100 & 150 & & \\
\hline 35 & 100 & 150 & & \\
\hline 36 & 100 & 150 & & \\
\hline
\end{tabular}

Table 5.1.Design of experiments. 


\begin{tabular}{|c|c|c|c|c|c|c|}
\hline \multirow{2}{*}{ Sl. No } & \multirow{2}{*}{$\begin{array}{c}\text { Conc of } \\
\text { sugars after } \\
\text { ACC }\end{array}$} & \multicolumn{3}{|c|}{ Total Sugars $(\mathrm{gm}) / \mathrm{L}$} & \multirow{2}{*}{$\begin{array}{c}\text { \% of conversion of } \\
\text { wood }(7 \% \text { in } 20 \mathrm{ml}= \\
1400 \mathrm{mg})\end{array}$} & \multirow{2}{*}{$\begin{array}{c}\text { \%of conversion } \\
\text { (holocellulose) } 70 \% \\
\text { of total mass of wood } \\
\text { used }(1400 \mathrm{mg})= \\
980 \mathrm{mg}\end{array}$} \\
\hline & & gm & $\mu$ & $\begin{array}{c}\text { S. Dev. } \\
\pm\end{array}$ & & \\
\hline 1 & 0.0981 & 98.10 & \multirow[b]{3}{*}{119.90} & \multirow[b]{3}{*}{36.81} & \multirow[b]{3}{*}{8.56} & \multirow[b]{3}{*}{10.12} \\
\hline 2 & 0.1624 & 162.40 & & & & \\
\hline 3 & 0.0992 & 99.20 & & & & \\
\hline 4 & 0.1684 & 168.40 & \multirow[b]{3}{*}{162.50} & \multirow[b]{3}{*}{5.14} & \multirow[b]{3}{*}{11.61} & \multirow[b]{3}{*}{16.22} \\
\hline 5 & 0.1601 & 160.10 & & & & \\
\hline 6 & 0.1590 & 159.00 & & & & \\
\hline 7 & 0.2210 & 221.00 & \multirow[b]{3}{*}{222.00} & \multirow[b]{3}{*}{6.46} & \multirow[b]{3}{*}{15.86} & \multirow[b]{3}{*}{23.36} \\
\hline 8 & 0.2161 & 216.10 & & & & \\
\hline 9 & 0.2289 & 228.90 & & & & \\
\hline 10 & 0.1754 & 175.40 & \multirow[b]{3}{*}{177.87} & \multirow[b]{3}{*}{2.32} & \multirow[b]{3}{*}{12.70} & \multirow[b]{3}{*}{18.37} \\
\hline 11 & 0.1782 & 178.20 & & & & \\
\hline 12 & 0.1800 & 180.00 & & & & \\
\hline 13 & 0.2268 & 226.80 & \multirow[b]{3}{*}{222.07} & \multirow[b]{3}{*}{4.24} & \multirow[b]{3}{*}{15.86} & \multirow[b]{3}{*}{22.31} \\
\hline 14 & 0.2208 & 220.80 & & & & \\
\hline 15 & 0.2186 & 218.60 & & & & \\
\hline 16 & 0.2889 & 288.90 & \multirow[b]{3}{*}{292.80} & \multirow[b]{3}{*}{4.29} & & \\
\hline 17 & 0.2921 & 292.10 & & & & \\
\hline 18 & 0.2974 & 297.40 & & & 20.91 & 30.35 \\
\hline 19 & 0.0968 & 96.80 & & & & \\
\hline 20 & 0.1016 & 101.60 & & & & \\
\hline 21 & 0.0982 & 98.20 & 98.87 & 2.47 & 7.06 & 10.02 \\
\hline 22 & 0.1105 & 110.50 & & & & \\
\hline 23 & 0.1054 & 105.40 & & & & \\
\hline 24 & 0.1115 & 111.50 & 109.13 & 3.27 & 7.80 & 11.38 \\
\hline 25 & 0.1126 & 112.60 & & & & \\
\hline 26 & 0.1658 & 165.80 & & & & \\
\hline 27 & 0.1467 & 146.70 & 131.63 & 3.64 & 10.12 & 14.97 \\
\hline 28 & 0.1305 & 130.50 & & & & \\
\hline 29 & 0.1357 & 135.70 & & & & \\
\hline 30 & 0.1287 & 128.70 & 104.97 & 5.93 & 9.40 & 13.13 \\
\hline 31 & 0.1648 & 164.80 & & & & \\
\hline 32 & 0.1657 & 165.70 & & & & \\
\hline 33 & 0.1579 & 157.90 & 162.80 & 4.27 & 11.63 & 16.11 \\
\hline 34 & 0.1662 & 166.20 & & & & \\
\hline 35 & 0.1781 & 178.10 & & & & \\
\hline 36 & 0.1745 & 174.50 & 172.93 & 6.10 & 12.35 & 17.81 \\
\hline
\end{tabular}

Table 5.2. Details of the yield of sugars after pretreatment using DNS assay method 

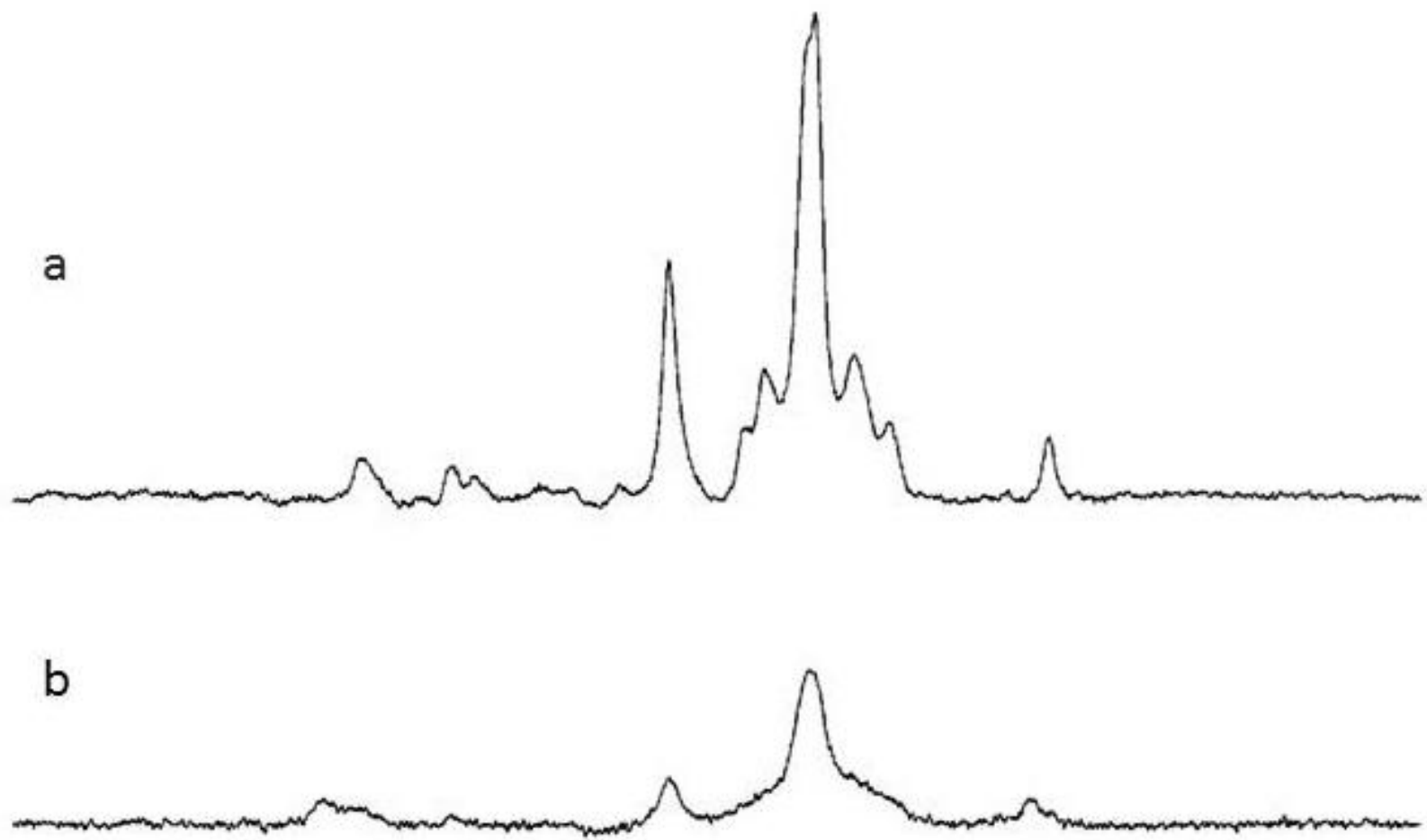

C
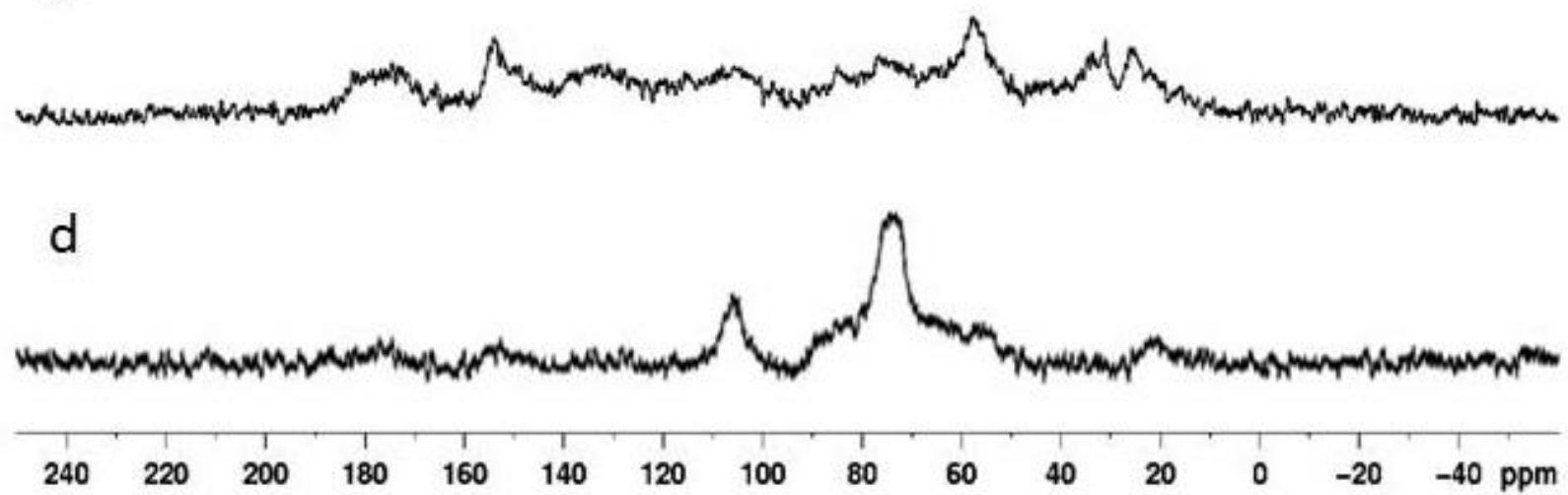

Figure 5.2. ${ }^{13} \mathrm{C}$ NMR spectra of cornstalk material obtained by ${ }^{1} \mathrm{H}-{ }^{13} \mathrm{C}$ cross polarization. (a) Control, (b) Willey milled samples. (c) and (d) Attrition milled samples. Spectra are obtained by signal averaging 320000-64000 scans using a 4 ms contact time and a 2.5 second recycle delay. 


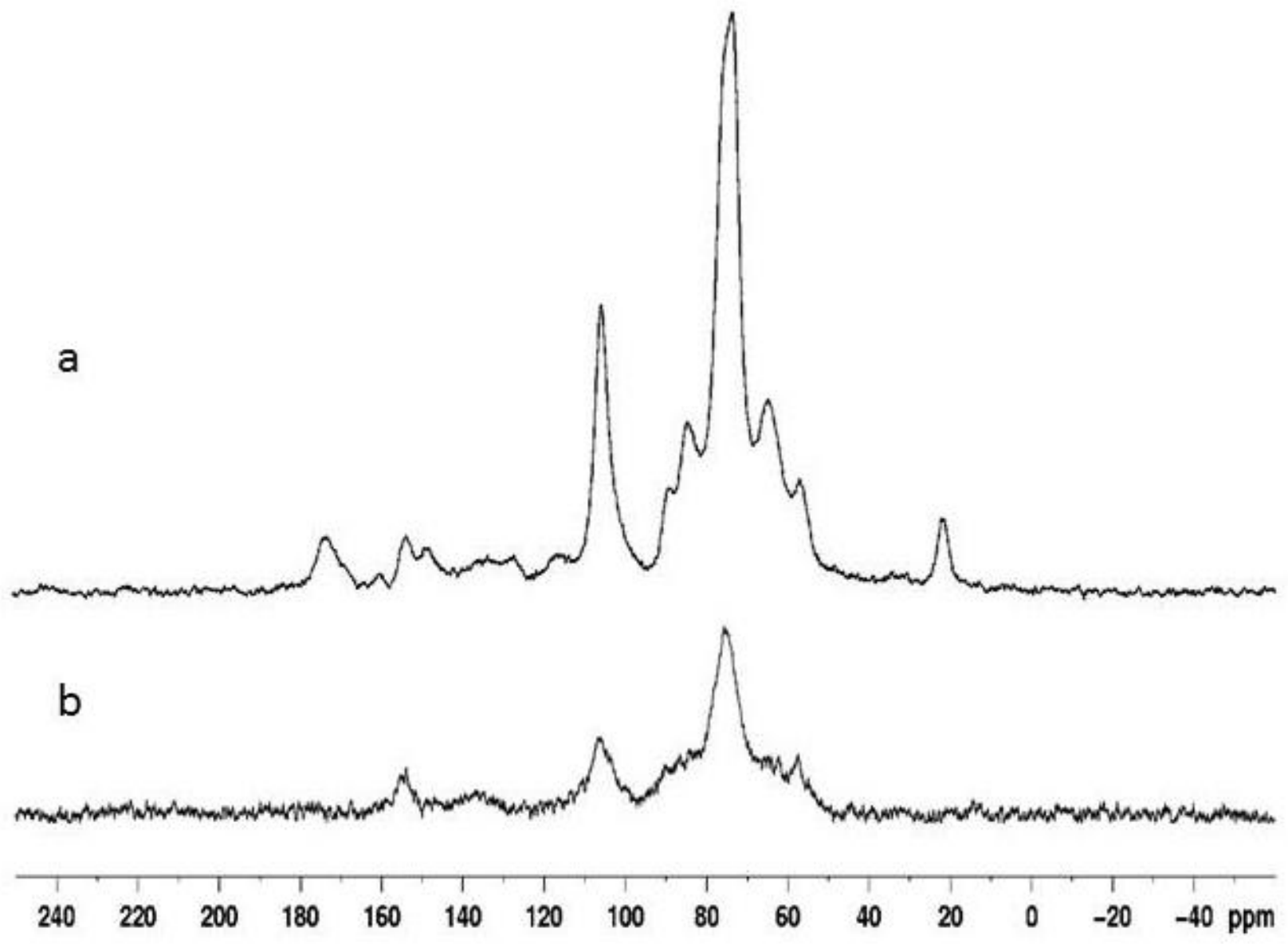

Figure 5.3. ${ }^{13} \mathrm{C}$ NMR spectra of cornstalk material obtained by ${ }^{1} \mathrm{H}^{13} \mathrm{C}$ cross polarization. (a) Corn control; (b) Attrition milled sample; Spectra are obtained by signal averaging about 32k scans using a 4 ms contact time and a 2.5 second recycle delay. 


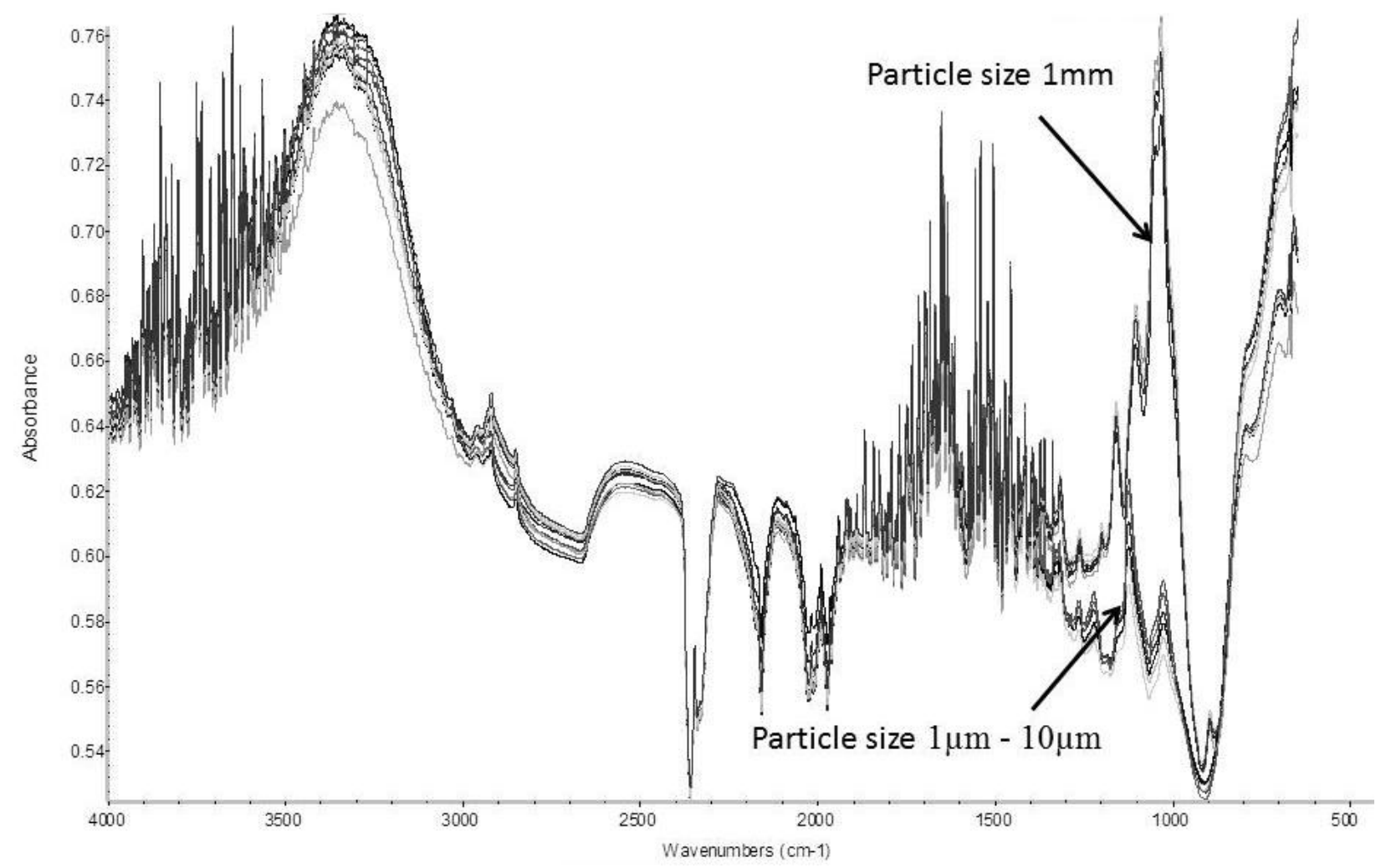

Figure 5.4. ATR-FTIR spectra of pretreated corn stover residue between 4000 and $500 \mathrm{~cm}^{-1}$ 

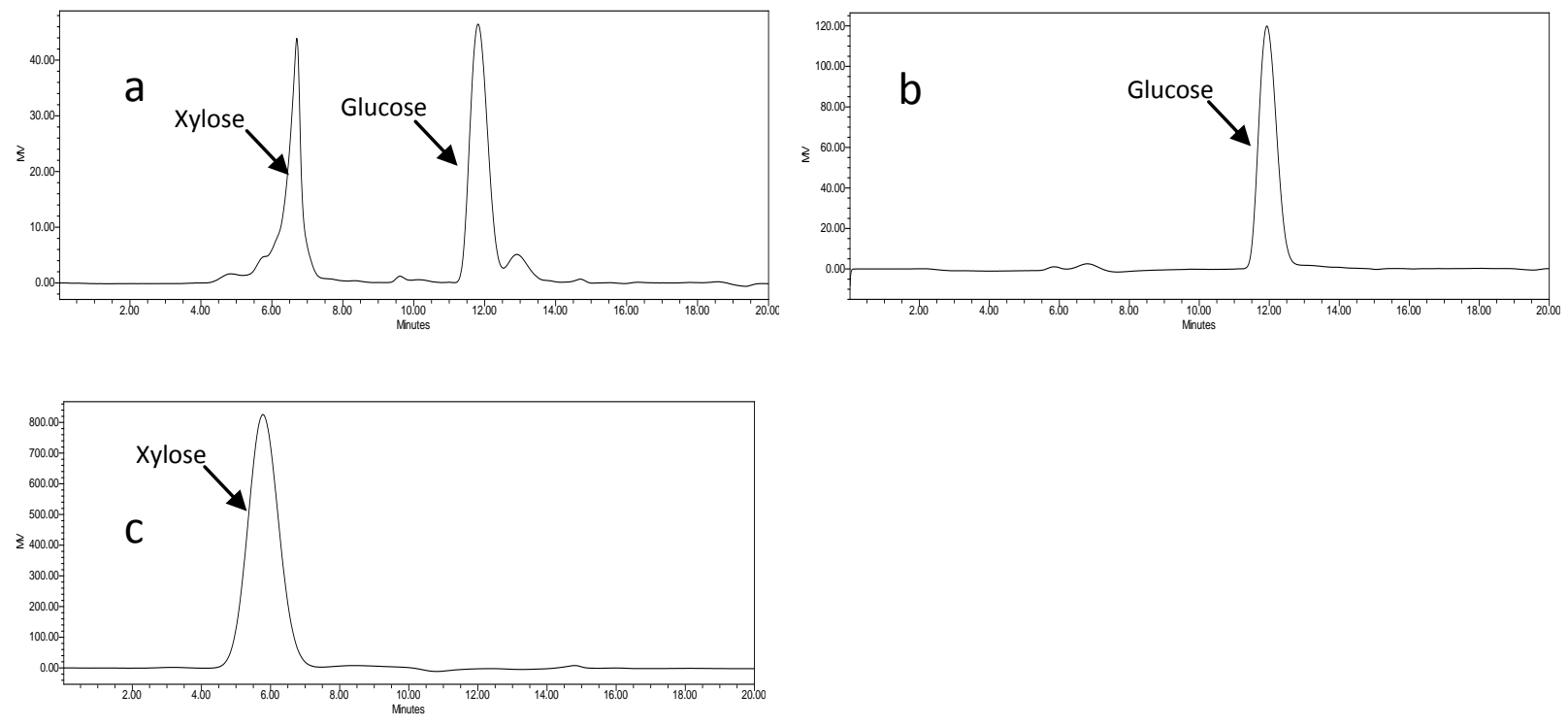

Figure 5.5.HPLC analysis for the presence of sugars after enzymatic treatment a. Pretreated sample b. Glucose standardc. Xylose standard 


\section{References}

Bak, J, S., Ko, J. K., Han, Y. H., Lee, B. C., Choi, I., Kim, K. H., 2009. Improved enzymatic hydrolysis yield of rice straw using electron beam irradiation pretreatment, Bioresource Technology, 100(3), 1285-1290.

Chosdu, R., Hilmy, N., Erizal, Erlinda, T. B. and Abbas, B., 1993. Radiation and chemical treatment of cellulosic waste, Radiat.Phys. Chem., 42 (4 -6), pp. 695 -698.

Chunping, Y., Zhiqiang, S., Guoce, Y. and Jianlong, W., 2008. Effect and aftereffect of $\gamma$ radiation pretreatment on enzymatic hydrolysis of wheat straw, Bioresource Technology, 99, pp. $6240-6245$.

Duarte, I.F., Barros, A., Delgadillo, I., Almeida, C. and Gil, A.M. 2002 Application of FTIR spectroscopy for the quantification of sugars in mango juice as a function of ripening, Journal of Agriculture and Food Chemistry 50 (2002), pp. 3104-3111

Garside, P. and Wyeth, P., 2003. Identification of Cellulosic Fibres by FTIR Spectroscopy: Thread and Single Fiber Analysis by Attenuated Total Reflectance, International Institute for Conservation of Historic and Artistic Works, 48(4), 269-275. Available from http://www.jstor.org/stable/1506916.

Gil, A. M. and Neto, C.P. 1999.Solid-state NMR studies of wood and other lignocellulosic materials. Annu. Rep. Spectrosc.,37, pp. 75-117.

Khan, F., Ahmad, S. R. and Kronfli, E. 2006. $\gamma$-Radiation Induced Changes in the Physical and Chemical Properties of Lignocellulose, Biomacromolecules, 7, pp. 2303-2309 
Kumakura., M, and Kaetsu, I., 1983. Effect of radiation pretreatment of bagasse on enzymatic and acid hydrolysis, Biomass, 3(3), 19, 199-208

Maunu, S.L, 2002. NMR studies of wood and wood products, Progress in Nuclear Magnetic Resonance Spectroscopy, 40, 151-174

Miller, G.L., 1959. Use of Dinitrosalicylic Acid Reagent for Determination of Reducing Sugar.Anal. Chem. 31, 426-428.

Shin, S. and Sung, Y. J., 2008. Improving enzymatic hydrolysis of industrial hemp (Cannabis sativa L.) by electron beam irradiation, Radiation Physics and Chemistry, 77(9), 1034-1038.

Sievers, C., Marzialetti, T., Hoskins, T. J., Valenzuela Olarte, M. B., Agrawal, P. K. and Jones, C. W., 2009. Quantitative solid state NMR analysis of residues from acid hydrolysis of loblolly pine wood, Bioresour. Technol., 100(20), pp.4758-65.

Yang, C., Shen, Z., Yu, G., Wang, J., 2008. Effect and aftereffect of $\gamma$ radiation pretreatment on enzymatic hydrolysis of wheat straw, Bioresource Technology, 99(14), 6240-6245. 


\section{CHAPTER 6. CONCLUSION AND RECOMMENDATION}

\subsection{Conclusion}

The study on the mechano-enzymatic pretreatment of both the lignocellulosic specimens (hard maple and corn stover) showed an elevated production of sugars. The each sequential treatment of depolymerizing enzymes had mixed results of which the treatments that showed the highest sugar yield with the minimum number of enzymes were evaluated. The enzymes responsible for the depolymerization of lignocellulosic cell wall for each substrate were different. The experiments also proved that BSA and CDTA had an enhancing effect on the increased activity and efficiency of the enzymes used. BSA binds to the lignin present in the reaction mixture decreasing the inhibitory effect of free lignin on the selective depolymerizing enzymes applied. CDTA increased the activity of pectinases and ferulic acid esterases by chelating the calcium ions that hold the poly-pectic bonds. CDTA removes calcium ions opening up the pectic polymers for the enzymes to breakdown cell wall biopolymers. Glucose and Xylose were released as monomers during the enzymatic hydrolysis.

Wet milling decreased the particle size, thereby, increasing the surface to volume ratio of the substrate. This makes the lignocellulosic substrates more accessible for cell wall deconstruction enzymes to selectively deconstruct cell wall biopolymers. Enzyme hydrolysis also reduced the particle size of lignocellulosic biomass. Two types of particle sizes were obtained after the enzyme hydrolysis. This reduction of particle sizes can be attributed the combined action of cell wall depolymerizing enzymes and wet milling. 
Elevated yield of total sugars was observed on increased enzyme concentration. Total of 59\% of holocellulose conversion was observed in corn stover and $45 \%$ was observed in hard maple. The difference in the total sugar yield might be due to the lignin content in hard maple specimens. The experiment proves that higher turnover of monosaccharides is possible at higher enzyme concentration levels.

Electron beams had a significant depolymerizing effect on lignocellulosic substrates but the yield of sugars was comparatively low. The maximum sugar yield was observed in wet milled specimens at the highest energy and dosage level. Particle size was one of the factors that control the depolymerization activity of electron beams. Release of other intermediate compounds or end products due to the action of electron beams also might have decreased the yield of monomeric sugars. Electron beams by itself is not viable. It has to be combined with any other cheaper thermo-chemical pretreatment methods to increase the efficiency of the cellulases and also to remove the inhibitors.

ATR-FTIR and ${ }^{13} \mathrm{C}$ NMR studies on the hydrolsates residues after the treatment with different enzyme concentrations and electron beams showed a noticeable decrease in the intensity of resonance vibration and resonance shifts of pretreated specimen compared to control. ATR-FTIR studies also showed traces of resonance vibrations at the sugar fingerprinting region which might be the sugar residues formed during the reaction. 


\subsection{Future Recommendations}

This work was a preliminary study to understand the depolymerizing effect of commercially available enzymes to selectively deconstruct cell wall biopolymers. The results shows that the sugar yield is low when compared to the available pretreatment techniques. Still there are limitations in the current study that has to be address in future.

1. The yield of total sugars directly is influenced by the accessibility of cell wall depolymerizing enzymes to its polysaccharides. Therefore, future studies have to be carried out to find out the most excellent sequence of enzymes that can increase the yield of total sugars.

2. Electron beams treatment has to be combined with other mid pretreatment methods like hot water treatment, or dilute hydrolysis sing electron beams by itself is not viable.

3. Application of cell wall depolymerizing enzyme after the electron beam treatment would be another area of research to find out the best pretreatment technique on lignocellulosic substrates.

4. Characterization studies on the byproducts and end products formed during the electron beam treatment has to be studied to increase monomeric sugar yield and also for a better understanding of the chemistry of the post electron beam treatment processes. 